Elisabeth Zolcsak

\title{
DIFUSÃO DE CONHECIMENTOS SOBRE O MEIO AMBIENTE
}

\section{NA INDÚSTRIA}

Tese de Doutoramento

apresentada ao

Departamento de Geografia

Faculdade de Filosofia, Letras e

Ciências Humanas

Universidade de São Paulo

Orientador Prof. Dr. Eduardo Yázigi

São Paulo, 2002 
Dedicatória

À minha mãe, pelo carinho 


\section{Agradecimentos}

Quero aqui, publicamente, agradecer ao meu Orientador, Professor Eduardo Yázigi, que com paciência me guiou, no mestrado e no doutoramento, especialmente pela inestimável consideração que teve com meu próprio tempo em busca de entendimento do trabalho acadêmico.

Agradeço também à Professora Rita de Cássia Ariza da Cruz e ao Professor Isak Kruglianskas pelos subsídios extremamente valiosos que me deram durante o exame de qualificação.

Deixo ainda registrado meu agradecimento ao Sr. William Zanellatto pela permissão de realizar parte do trabalho na empresa Unilever - Elida Gibbs - Vinhedo, SP, e pela cordialidade que muito me apoiou.

Não posso deixar de lembrar e agradecer a todos os funcionários daquela empresa que gentilmente se dispuseram às entrevistas.

Da Prefeitura de Vinhedo, agradeço a colaboração da Sra. Flávia Pozzuto, da Secretaria Municipal de Meio Ambiente, e de todos os outros funcionários que me atenderam por vezes com valioso bom humor.

Em outras instituições, muitas pessoas contribuíram com minhas buscas e levantamentos tornando as atividades sempre mais leves, pelo que agradeço a todos mesmo sem citá-los nominalmente.

Assim também lembro, com carinho, de todos os colegas que compartilharam comigo as orientações do Prof. Eduardo e acompanharam o desenrolar deste trabalho com companheirismo.

Agradeço ainda o apoio da Professora Arani Nanci Bomfim Mariana que me possibilitou conciliar atividades profissionais com as etapas finais deste trabalho.

A Rosângela Costa Araújo 'Janja', a amigos que de perto ou de longe me acompanharam, a Cristina, Sandro Júnior e Bruno, meus afetuosos agradecimentos.

Elisabeth Zolcsak 


\section{Sumário}

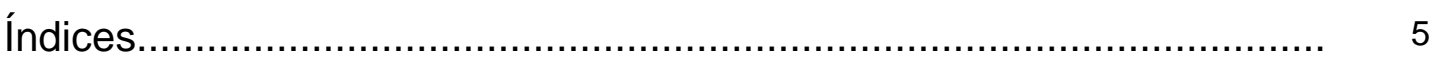

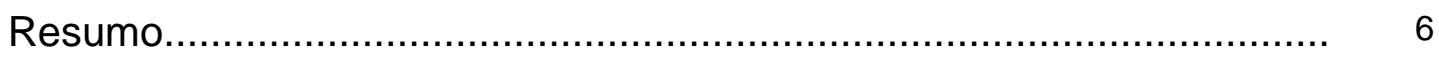

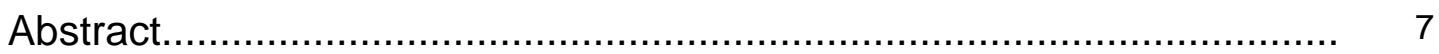

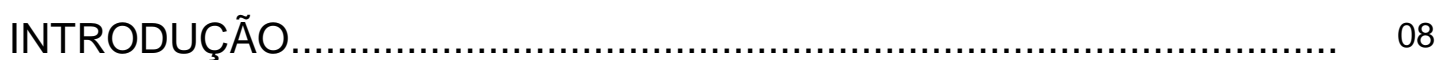

Inserção do estudo na Geografia....................................................... 19

1. MODELOS MENTAIS SOBRE O AMBIENTE................................... 21

1.1 Construção e valorização do conhecimento científico..................... 29

1.2 Conhecimento científico sobre o ambiente.................................... 38

2. PROTEÇÃO AMBIENTAL EM EMPRESAS..................................... 41

2.1 Sistemas de gestão ambiental e norma ISO $14001 \ldots \ldots \ldots \ldots \ldots \ldots \ldots \ldots . . . . . . . .52$

3. DIFUSÃO DE CONHECIMENTOS AMBIENTAIS NA INDÚSTRIA:

FÁBRICA UNILEVER EM VINHEDO, SP ............................................ 61

3.1 O município de Vinhedo.......................................................... 61

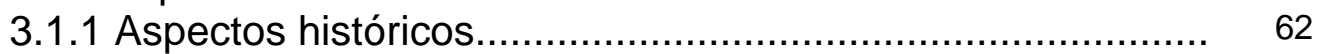

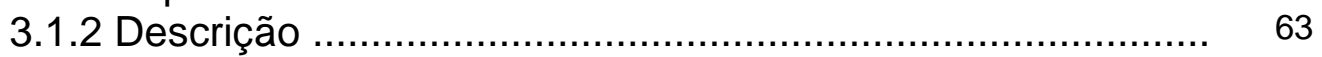

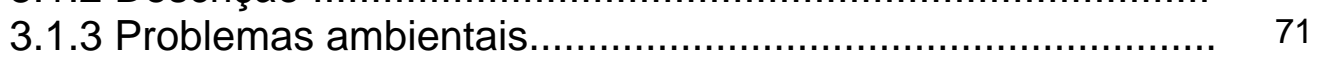

3.1.3.1 Recursos hídricos................................................. 71

3.1.3.2 Resíduos sólidos, áreas verdes e loteamentos............. 82

3.1.4 Ações para melhoria e preservação ambiental..................... 83

3.1.4.1 Ações ambientais da Prefeitura Municipal................... 85

3.1.5 O modelo acadêmico de meio ambiente.............................. 88

3.2 A empresa Unilever - Divisão Elida Gibbs.................................. 92

3.2.1 Divisão Elida Gibbs - Unilever - em Vinhedo...................... 93

3.2.2 Relações com a comunidade e educação de funcionários... 96

3.2.3 Aspectos ambientais gerais da indústria química................. 98

3.2.4 A questão ambiental no Grupo Unilever............................... 99

3.2.5 A fábrica de Vinhedo e o meio ambiente............................ 104

3.2.6 O modelo empresarial de meio ambiente............................ 106

3.3 Resultados das entrevistas com funcionários da Divisão

Elida Gibbs - Unilever - em Vinhedo, SP........................................ 109

3.3.1 O modelo de meio ambiente do senso comum.................... 118

4. RETOMADA DO DIÁLOGO ENTRE OS MODELOS DE MEIO AMBIENTE

4.1 Difusão de conhecimentos sobre o meio ambiente para atitudes valorativas e participativas.

CONSIDERAÇÕES FINAIS........................................................... 138

REFERÊNCIAS BIBLIOGRÁFICAS................................................... 139 


\section{Índices}

Figuras

01 Localização do município de Vinhedo em São Paulo.................... 62

02 Município de Vinhedo - zoneamento........................................ 67

03 Localização de Vinhedo, SP, em relação às bacias hidrográficas dos rios Piracicaba, Capivari e Jundiaí.

04 Unidades de Gerenciamento de Recursos Hídricos no Estado de São Paulo.

$\begin{array}{lll}05 & \text { Município de Vinhedo com localização da fábrica Unilever............ } & 94 \\ 06 & \text { Croquis da empresa Elida Gibbs - Unilever - Vinhedo, SP } & 95\end{array}$

07 Impresso educativo Elida Gibbs para crianças........................... 96

08 Impresso educativo Elida Gibbs para consumidores.................. 97

09 Impresso educativo Elida Gibbs para funcionários...................... 97

10 Município de Vinhedo - bairros............................................... 115

\section{Tabelas}

$01 \quad$ Demografia do Brasil em 1991,1997 e 2000.............................. 42

02 Características demográficas de Vinhedo-1980 -1996................ 65

03 Desempenho ambiental-tonelada de produtos-Unilever-1995-99.. 103

04 Desempenho ambiental e produção total-Unilever-1995-99......... 103

05 Estágios evolutivos de gestão ambiental corporativa................... 107

06 Características (idade e gênero) da amostra de funcionários da empresa Elida Gibbs - Unilever, Vinhedo, SP, 2001.................. 110

\section{Gráficos}

01 Tempo de residência em Vinhedo da amostra de funcionários da empresa Elida Gibbs - Unilever, por gênero.

02 Tempo de trabalho na empresa da amostra de funcionários da empresa Elida Gibbs - Unilever, por gênero.

03 Tempo de trabalho na empresa e tempo de residência em Vinhedo da amostra de funcionários da empresa Elida Gibbs.......

04 Freqüências das questões ambientais apontadas em Vinhedo pela amostra de funcionários da empresa Elida Gibbs.

05 Freqüências das questões ambientais apontadas em Vinhedo pela amostra de funcionários da empresa Elida Gibbs; distribuição das categorias por bairros de moradia.

06 Freqüências das questões ambientais apontadas em Vinhedo pela amostra de funcionários da empresa Elida Gibbs; distribuição das categorias por bairros de moradia e por gênero... 


\section{Resumo}

Para análise da difusão de conhecimentos sobre o meio ambiente na gestão ambiental da indústria esta tese toma em vista três modelos mentais de meio ambiente - o modelo acadêmico, o empresarial e o modelo do senso comum. Após conceituar estas representações mentais de meio ambiente e expor especificidades da proteção ambiental em empresas, apresenta um estudo de caso efetuado na empresa Unilever - Divisão Elida Gibbs, em Vinhedo, São Paulo.

Analisa o diálogo entre os modelos empresarial e do senso comum face ao conhecimento ecológico e discute que a educação ambiental, dos trabalhadores de uma empresa e de modo geral, deve se pautar em história natural e se desdobrar em uma educação para o planejamento ambiental visando incrementar a percepção judicativa e a capacidade de participação dos cidadãos na construção do espaço.

\section{Palavras-chave}

conhecimento ambiental, gestão ambiental, construção do espaço, educação ambiental, representação social 


\begin{abstract}
This research refers to three mental models of environment - the scientific model, the industrial model and the common sense model - to analyze the diffusion of environmental knowledges carried out by industrial environmental management systems. Besides theoretical considerations about mental models of environment and environmental conservation at industry, the research presents a case focused on Unilever industrial plant at Vinhedo, São Paulo.

The research takes aim to lights on the dialogue between industrial and common sense mental models of the environment in the face of ecological knowledge and discuss educational activities based on natural history and especially on environmental planning to improve evaluative perceptions and participatory abilities of citizens in the production of space.
\end{abstract}

\title{
Keywords
}

environmental knowledge, environmental management,

production of space, environmental education, social representation 


\section{INTRODUÇÃO}

O tema deste estudo é a difusão de conhecimentos sobre o meio ambiente na gestão ambiental da indústria.

O interesse se afunila para a indústria porque, como todas as outras atividades econômicas, a atividade industrial pode causar grandes alterações e degradações ambientais, talvez não maiores do que as atividades agrícolas, de mineração, de produção de energia e de construção civil, mas geralmente muito próximas às aglomerações humanas onde é importante a valorização e o resgate da qualidade ambiental.

A atividade industrial utiliza recursos naturais como matéria-prima e como elementos de infra-estrutura e causa impactos ambientais pelo uso direto ou indireto dos recursos, pelos processos produtivos e através dos produtos fabricados.

Algumas indústrias, para maximizar o uso de recursos naturais e por necessitar de avaliação, prevenção e controle dos impactos ambientais causados, já organizam sistemas de gestão ambiental com procedimentos para conservação e manejo do meio ambiente.

A gestão ambiental das empresas tem focos amplos, incluindo exploração de recursos e preocupações com os produtos (pós-consumo), ou focos mais restritos aos processos produtivos. $\mathrm{O}$ foco aqui considerado é a gestão ambiental de impactos causados pelos processos produtivos.

O sistema de gestão ambiental das empresas utiliza conhecimentos sobre a estrutura e dinâmica dos ecossistemas, e difunde estes conhecimentos aos seus funcionários quando inclui atividades de educação ambiental em seus programas de gestão, talvez reconstruíndo-os por pontos de vista próprios da atividade empresarial.

Vemos esta difusão de conhecimentos sobre o meio ambiente como fator da construção do espaço por entender esta construção como fruto de atitudes influenciadas, em graus variados, por conhecimentos adquiridos pelos indivíduos. 
Considerando conhecimentos como representações (ou modelos) mentais, o estudo toma em vista três modelos mentais de meio ambiente.

O primeiro destes modelos, que denominamos modelo acadêmico, é aquele constituído pelo conhecimento acadêmico sobre a estrutura e funcionamento de ecossistemas, pertinente à disciplina da Ecologia.

O segundo modelo mental de meio ambiente aqui considerado é aquele que se forma em uma empresa (em nível diretivo e gerencial) e que conduz as ações de gestão ambiental. Denominamos este modelo como modelo empresarial de meio ambiente.

O terceiro modelo a que nos referimos é aquele que se forma do conhecimento de meio ambiente que os funcionários (trabalhadores de linhas de produção) de uma empresa apresentam e que denominamos modelo do senso comum.

O termo "modelo mental" que utilizamos significa forma de representação mental do mundo externo. É expressa por ações, fala, escrita, desenho ou por objetos.

Como o modelo mental é mediado pelas sensações objetivas, pela individualidade e também pela interveniência social, onde se inserem os valores culturais, a memória coletiva e o conhecimento adquirido, é interpretação do mundo.

Em sentido comum, o que uma pessoa ou grupo de pessoas pensa, fala ou faz sobre o ambiente, tendo recebido inúmeras influências, significa seu modelo mental do ambiente. E são os modelos mentais, ou seja, as interpretações do mundo, que conduzem as ações sobre o mundo.

Oras, se falamos em interpretação, que remete à subjetividade, se assim assumimos que nenhuma verdade científica se impõe no sentido absoluto, caímos no risco do relativismo puro onde todo conhecimento só possui sentido para o sujeito individual ou para uma coletividade por consenso. Negamos esta posição extrema do relativismo que não se pauta na realidade objetiva. Optamos por reconhecer a possibilidade de existir uma verdade absoluta que a ciência, ou outras formas de conhecimento, persegue. 
Encontramos melhor abrigo para nosso posicionamento na definição de Hilton Japiassu (2001: 54) para relativismo científico ou epistemológico que se refere a uma ciência que constrói imagens do real com coerência e lógica interna mas em constante modificação em busca do real absoluto e inacessível.

Também nos afastamos de extremos do relativismo cultural (cujo ponto positivo é, sem dúvida, a tolerância, mas cujo risco é o conformismo e a ausência de crítica) mas reconhecemos a diversidade das culturas como um antídoto ao cientificismo cujos problemas são a valoração dogmatizada da racionalidade científica ocidental e etnocêntrica e a negação de variadas visões de mundo e da natureza.

Isto posto, retomamos que dentro do tema selecionamos como objetos de estudo os modelos mentais de meio ambiente que conduzem as ações de gestão ambiental em uma indústria (modelo empresarial) e os modelos que são influenciados por estas ações (modelo do senso comum), face ao modelo acadêmico que se aplica para determinada localidade.

Como esquema destes modelos (ou representações) mentais de um ambiente temos:

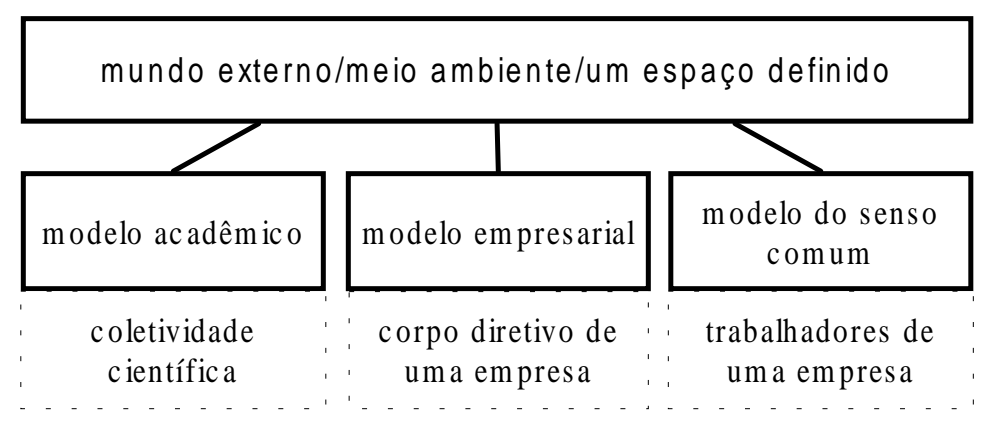

Estes modelos são definidos por nós a partir de conjuntos de indivíduos que têm atividades diferentes na sociedade e, portanto, leituras diferentes do ambiente. Mas não são modelos estanques pois se estabelece um diálogo entre eles. 
Temos em mente que o diálogo entre os diversos modelos navega sobre valores diversos da ciência, dos aspectos econômico-sociais dos meios de produção, da educação em seu sentido amplo, da consciência ambientalista, da apreciação da natureza e da individualidade.

Conceitos e teorias sobre ecossistemas partem de uma coletividade científica e se aplicam aos ambientes. Ou seja, estes conceitos e teorias ecológicas, como conhecimento adquirido, podem influenciar a forma de se ver um ambiente, podem conduzir as interpretações e análises aproximando o modelo mental dos sujeitos que adquirem este conhecimento daquele modelo acadêmico de meio ambiente formado na coletividade científica.

O modelo empresarial de meio ambiente, que transparece nos documentos e procedimentos do sistema de gestão ambiental, pode assim estar, em maior ou em menor grau, permeado com conceitos e teorias ecológicas, como também pode estar o modelo de meio ambiente que denominamos modelo do senso comum.

Por sua vez, o modelo acadêmico formado por conhecimento científico ecológico é visto como uma baliza para a análise da difusão de conhecimento sobre o meio ambiente. Isto porque, para a maioria dos temas ambientais e de desenvolvimento atuais, as ciências, enquanto forma de conhecimento, posturas e habilidades, são importantes para detectar e analisar problemas, identificar soluções e propor políticas e ações com pensamento crítico.

Seguindo as observações que fizemos, para ampliar a compreensão da difusão de conhecimentos sobre o meio ambiente na indústria optamos por verificar como se dá o diálogo entre os modelos de meio ambiente empresarial e do senso comum de forma a incrementar a valorização ambiental e a participação de ambas as partes, empresa e seus trabalhadores, na construção do espaço com qualidade ambiental.

É um problema referente ao papel de determinada política, enquanto ação institucional, na organização espacial e na valorização do meio natural e humano e exercido por meios informacionais. 
Justificamos nosso interesse em contribuir para o entendimento do diálogo entre grupos com funções distintas na sociedade pela existência de problemas ambientais que demandam maior conscientização de todos para novas atitudes com o meio ambiente.

Nos problemas de preservação ambiental considera-se que atividades sociais, econômicas e políticas modificadas podem levar à proteção do meio ambiente, a melhorias na qualidade ambiental e ao desenvolvimento sustentável. As principais modificações nestas atividades devem ser demográficas (crescimento e distribuição da população) e devem envolver modos de produção e padrões de consumo.

Porém, o agente destas novas atividades necessárias é aquele homem em um local de ação.

Vemos como necessárias novas atitudes em relação ao uso e ocupação do solo, a padrões e níveis de consumo, a manifestações coletivas para solicitação ou cumprimento de legislação. E consideramos que atitudes dependem de conhecimentos e de valorização ambiental por parte da comunidade em geral.

Assim julgamos importante que as atitudes e modos de pensar a relação homem-meio, que transparecem como os modelos mentais de meio ambiente destes agentes imediatos, sejam revelados e alimentados com novas perspectivas e possibilidades para as escolhas críticas.

No interesse de estudar a difusão de conhecimentos ambientais em um cenário empresarial temos como objetivo apresentar os modelos mentais de meio ambiente de grupos com funções distintas na sociedade mas em relação direta de influência.

Apresentando tais modelos analisamos o diálogo entre empresa e seus trabalhadores $\mathrm{e}$ discutimos sobre as possibilidades $\mathrm{e}$ responsabilidades institucionais, coletivas e individuais de contribuir com a valorização ambiental através de ações diretas sobre o meio e através de ações educativas. 
Partimos da hipótese que o diálogo entre os modelos empresarial e do senso comum conduzindo a atitudes valorativas e participativas em relação ao meio ambiente deve se basear em conhecimento ecológico e a educação ambiental dos trabalhadores de uma empresa deve se pautar também em história natural e ser voltada para a localidade que habitam.

No decorrer da pesquisa acrescentamos o planejamento ambiental como tópico importante na educação ambiental dos indivíduos.

No estudo, apresentamos o primeiro capítulo para trazer mais clareza ao conceito de modelos mentais de meio ambiente indicando seus possíveis dinamismos.

Adiantamos que para abordar modelos de ambiente, ou várias representações mentais de ambiente, reconhecemos diversas visões de mundo e diversas formas de aquisição e uso de conhecimentos.

Visões de mundo se ligam ao cotidiano das pessoas. Berger e Luckmann (1990: 12) consideram que as pessoas comumente não se preocupam com o que é real para elas e com o que conhecem a não ser que esbarrem com alguma espécie de problema. Isto significa, ainda para estes autores, que não se deve exagerar a importância do pensamento teórico na sociedade, seja ele científico ou filosófico ou mitológico, porque não esgota o que é real para os membros de uma sociedade.

O real é o mundo da vida cotidiana, havendo atenção pragmática e a apreensão ordenada e mediada pela linguagem da realidade da vida diária. Interesses distantes da vida cotidiana são questões de escolha privada (id. ib.: 40).

A noção do acervo do conhecimento social estar "estruturado em termos do que é geralmente relevante e do que é somente relevante para papéis particulares" (id. ib.: 107) reforça a distinção que fizemos de modelos mentais de meio ambiente ligados a funções distintas na sociedade. 
No capítulo 1, ao lado da conceituação de modelos mentais, abordamos a aquisição e uso de conhecimentos sobre o meio ambiente e a valorização do conhecimento científico.

Nesta linha reconhecemos, como afirma Gerard Fourez (1995: 67), que nossos modelos do mundo partem da vida cotidiana ligada à cultura e que "os sistemas teóricos aparecem como interpretações que organizam a nossa percepção do mundo" quando queremos fazer algo. Para Fourez os modelos não são subjetivos por serem instituições sociais ligadas a projetos, a técnicas.

Ainda fazemos notas sobre o modelo acadêmico de meio ambiente concordando com Fowler e Aguiar (1995: 166) quando afirmam que "o manejo do ambiente demanda um conhecimento dos padrões e processos dos sistemas biológicos". Este conhecimento possibilita o desenvolvimento de procedimentos de análise e avaliação quando se visa à conservação dos recursos biológicos.

Fowler e Aguiar (1995) afirmam ser imprescindível a análise ambiental com bases ecológicas, ou seja, a análise que envolva os atributos da escala ecológica, de ecossistemas até indivíduos, passando pelas comunidades e populações. Mas julgam que a análise ambiental serve apenas para identificar, não para controlar problemas.

Concordamos que o controle dos problemas ambientais depende dos cidadãos que estabelecem, com seus modelos mentais, os valores dos atributos ambientais que são estudados ou considerados. Isto nos retoma 0 problema em estudo e sua seqüência.

Nos referimos no início a sistemas de gestão ambiental e nosso foco está em sistemas certificados pela norma ISO 14001.

A ISO - International Standardization Organization - atua para harmonizar as diversas agências nacionais de normas, sendo a agência brasileira a ABNT - Associação Brasileira de Normas Técnicas.

A série de normas ISO 14000 se dedica a gestão ambiental de processos e produtos e a norma ISO 14001 orienta os sistemas de gestão ambiental de empresas. 
Os sistemas de gestão ambiental, quando seguem a norma ISO 14001, fornecem às organizações condições para estabelecer uma política ambiental apropriada; determinar os requisitos da legislação associadas às atividades, produtos e serviços da organização; desenvolver o compromisso dos funcionários com a proteção ambiental; estabelecer um processo de gestão apropriado; e fornecer recursos para as atividades de proteção ambiental.

A certificação de uma empresa pela norma ISO 14001 visa garantir o seguimento da norma e assim é indicativa de preocupação com o meio ambiente e atuação consciente no espaço coletivo, cuja análise é objetivo deste estudo.

Garante também a implantação sistemática e documentada da gestão ambiental e o treinamento em questões ambientais de diversos escalões de funcionários, o que leva ao processo de difusão de conhecimentos sobre o meio ambiente.

Assim, descrição de sistemas de gestão ambiental, seus procedimentos gerais, requisitos e mecanismos para a certificação pela norma ISO 14001, antecedida por notas sobre os aspectos históricos da proteção ambiental de caráter preventivo partindo de agentes poluidores, compõe o capítulo 2 deste trabalho para possibilitar entendimento da lógica empresarial na questão ambiental.

No capítulo 3 apresentamos nossa pesquisa em campo.

Como estratégia de investigação fizemos um estudo de caso, com a escolha de uma indústria em determinada localidade, para nos representar concretamente o problema auxiliando no tratamento da hipótese apresentada.

Formamos a simplificação de um sistema complexo por abstração dos elementos essenciais ao fenômeno em questão, ou seja, o papel da gestão ambiental da empresa na organização do espaço pela difusão de conhecimentos sobre o meio ambiente. 
A opção recaiu na Unilever Higiene e Beleza em Vinhedo, no Estado de São Paulo. Até o segundo semestre de 2001 esta fábrica portava a denominação Divisão Elida Gibbs das Indústrias Gessy Lever Ltda. - Divisão de produtos de higiene pessoal.

Os critérios de escolha da empresa para estudo de caso foram:

1. a ocorrência de gestão ambiental sistematizada e certificada de acordo com a norma ISO 14001, pelas razões expostas anteriormente;

2. a localização da indústria em um pequeno município (considerando a população, com menos de 50 mil habitantes) de São Paulo.

Sobre este segundo critério, consideramos que em um pequeno município podemos equacionar com mais acuidade os modelos de meio ambiente que temos como objeto de estudo, voltados para um espaço.

Com mais detalhe, este critério possibilita melhor análise das percepções dos trabalhadores da empresa em relação ao espaço geográfico que habitam, indicativas de conhecimentos ambientais.

Não descartamos a complexidade do conceito 'percepção ambiental', mas utilizamos o termo como consciência, ou "capacidade de gerar informação", como nos explica extensivamente Ferrara (1993).

O termo 'percepção' também nos remete ao reconhecimento da existência de imagens comuns, que são, por exemplo, as que interessam aos planejadores que buscam um desenho de ambiente que muitos desfrutem. As imagens mentais comuns aparecem "na interação de uma realidade física única, uma cultura comum e uma natureza psicológica básica" (Lynch, 1960: 17), consideração esta que, em sentido restrito, nos levou ao estudo de caso dentro de um universo único.

Para o primeiro critério nosso universo era de 191 instalações empresariais certificadas pela norma ISO 14001 no Brasil, em fins de 2000*.

São Paulo apresentava 82 instalações certificadas, sendo 68 industriais. Um universo de 8 fábricas correspondeu ao nosso segundo critério. E, deste, optamos por uma fábrica que nos apresentou condições para analisar a interação empresa-trabalhadores.

*(fonte INMETRO - Instituto Nacional de Metrologia, Normalização e Qualidade Industrial) 
Consideramos que o caso representa o problema e se torna uma unidade significativa. É tanto um exemplo elucidativo quanto um recorte da realidade em seus traços essenciais, suficientes para a análise da situação em estudo.

Seguimos Becker (1999: 128) quando considera que em um estudo de caso que tem como foco determinada estrutura social "eliminamos o que é historicamente único e nos concentramos nas propriedades genéricas do grupo, visto como um exemplo de um tipo específico de estrutura".

Com 'propriedades genéricas do grupo', Becker se refere às partes fundamentais do grupo, ou melhor, às relações que se estabelecem entre as partes fundamentais do grupo. Dá como exemplo um estudo de uma escola para descobrir-se quais são as formas de interação numa instituição na qual uma classe de participantes está presente involuntariamente.

$O$ autor que citamos defende que as descobertas poderiam ser aplicadas, em seus termos gerais, a outras instituições com as mesmas características.

Muito refletimos sobre nosso método e estratégia, atentando para os questionamentos que permeiam as ciências humanas e as pesquisas qualitativas. Porém consideramos que nosso estudo de caso permite descobertas e reflexões, não apenas sobre uma empresa, mas sobre a estrutura 'espaço-empresa-trabalhadores'.

Tendo definido o cenário do estudo de caso, buscando unidade de análise, abordamos mais especificamente as questões de conservação ambiental (problemas e soluções) para inferir o modelo de meio ambiente de cada parte.

Realizamos coleta de dados em instituições e documentos técnicos, além de observações em campo e entrevistas com funcionários da empresa, utilizando esta última técnica com o objetivo principal de identificar a variedade de dados, não para medi-la.

A análise dos dados se baseou em interpretação e construção de explicações. 
Assim, no capítulo 3 apresentamos o estudo de caso em 3 subcapítulos.

O primeiro subcapítulo descreve o município de Vinhedo e traz dados bibliográficos de pesquisas ambientais realizadas na região deste município. Reflete o espaço do estudo e o modelo acadêmico de meio ambiente, discutido em seu final.

O segundo subcapítulo descreve a fábrica Unilever em Vinhedo e os aspectos ambientais que considera, levando a uma análise do modelo empresarial de meio ambiente.

O terceiro subcapítulo traz os resultados das entrevistas feitas com funcionários das linhas de produção da mesma empresa. Apresenta, ainda, a discussão do modelo de meio ambiente que denominamos modelo do senso comum.

No capítulo 4, retomamos a hipótese apresentada à luz do diálogo que podemos estabelecer entre os modelos de meio ambiente que definimos.

Queremos, ainda, explicitar as áreas às quais julgamos trazer, mais diretamente, uma contribuição com este estudo.

A preocupação com a formação de modelos mentais remete este estudo à epistemologia em seu sentido amplo, à reflexão sobre o saber, sua formação, organização, desenvolvimento, funcionamento e seus produtos intelectuais.

Mas o trabalho é fundamentalmente um estudo da ação do homem sobre o meio; da interação entre fenômenos humanos (interpretação, cognição, vida social, política e econômica) e o ambiente com seus inúmeros fatores bióticos e abióticos.

Pretende assim contribuir para os campos da Geografia e das Ciências Ambientais, trazendo reflexões sobre sistemas de gestão ambiental como ações públicas e de responsabilidade social e educativa sobre o espaço.

Finalizando esta Introdução, apresentamos, em tópico distinto, notas sobre os caminhos que percorremos na Geografia. 


\section{INSERÇÃO DO ESTUDO NA GEOGRAFIA}

Analisando definições dadas por autores como Carlos (1999), Conti (1999), Coltrinari (1999) e Moraes (1983) compreendemos a ciência geográfica como disciplina que aborda a realidade através da análise do espaço, de sua forma, formação e transformação.

Ana Fani Alessandri Carlos (1999: 179) caracteriza este espaço geográfico - em relação ao homem que o constrói como "o espaço dominado" que "impõe não apenas modos de apropriação, mas comportamentos, gestos, modelos de construção que excluem/incluem".

É nota importante para o foco deste estudo que se preocupa com a apropriação de espaços por grupos de indivíduos com papéis distintos na sociedade.

Retomando a dinâmica e transformação do espaço geográfico, a compreendemos como o quadro de vida que Dollfus (1991: 120) apresenta, com um conteúdo sociológico e um conteúdo biológico e estético referentes às relações dos homens entre si e com o meio natural.

O diálogo entre os conhecimentos diversos surge então como relação entre os homens, entre estes e o meio natural, e, esta relação, traz uma faceta que Moraes (1997: 9) denomina "questão ambiental", desfavorável quando se caracteriza por "conquista territorial", "padrão dilapidador dos recursos", "Estado patrimonial" e "Sociedade excludente".

Milton Santos (1996) nos traz o conceito de realidade social, indicando principalmente a imposição de valores sobre a realidade física, que vemos como importante para o entendimento que buscamos do diálogo entre os diversos conhecimentos de meio ambiente.

Relacionamos este diálogo entre conhecimentos à produção de espaço e às responsabilidades ambientais que levam à discussão sobre sustentabilidade e questões urbanas.

Swyngedouw (1997: 329) observa que o reconhecimento da produção social da natureza e da cidade é muito importante se sustentabilidade significar um desenvolvimento urbano justo com distribuição de poder. 
Considerando o espaço vivido pelo homem, a questão urbana assume muita relevância e o estudo de Swyngedouw (1997) busca aproximar perspectivas ecológicas, políticas e de urbanização com uma teoria crítica social e cultural. Discute a construção do conhecimento como construtora da materialidade da socionatureza (expressão já indicativa de coisa produzida) e remete a conceitos de Henri Lefebvre.

Lefebvre (1995), filósofo que contribuiu para a sociologia urbana e para os estudos urbanos em geral, no início da década de 70, considera 0 espaço um elemento da produção da sociedade, em duplo sentido, ou seja, o espaço faz produzir como também é produzido, através da articulação entre forças econômicas, políticas e culturais.

A preocupação de Lefebvre é o espaço capitalista pulverizado pela propriedade privada e pela capacidade científica e técnica (porque econômica) diferenciada entre as classes sociais. Aponta a necessidade de transformação das relações sociais para a preservação do espaço com seus múltiplos propósitos.

Sua compreensão da construção social de espaço baseada em práticas materiais, representacionais e simbólicas em constante dinamismo vem recebendo aportes conceituais de geógrafos e outros estudiosos do espaço.

Encerrando este breve tópico, chamou-nos atenção o trabalho de Marcel Roncayolo (1996) discutindo que as cidades não se reduzem aos objetos ou a uma combinação de funções. Pelo contrário, a razão da organização territorial são as funções, a população e as instituições.

Roncayolo vê a função urbana mais como uma forma anterior do que como conteúdo e retoma a revolução de funções para resolução de problemas, dando importância à política exercida por comunidades locais e às questões de identidade como elementos estruturantes do território. 


\section{MODELOS MENTAIS SOBRE O AMBIENTE}

Definimos como objeto de estudo modelos mentais de meio ambiente. Vamos, neste capítulo, expor suas conceituações do trabalho de inúmeros pesquisadores envolvidos basicamente com filosofia da ciência e educação.

Modelos mentais são formas de representação do mundo expressas por ações, fala, escrita, desenho ou por objetos. Envolvem elementos interrelacionados e se referem a situações dinâmicas. Metaforicamente, "são como filmes" (Creso, 1999: 281).

São mediados, ou melhor, construídos, por sensações objetivas, pela individualidade, por valores culturais e pelo conhecimento adquirido.

De acordo com Brewer (1999), em sua revisão da psicologia cognitiva recente, representações mentais são imagens, esquemas e teorias. Mas este autor afirma que imagens não têm riqueza representacional e esquemas, também sem tal riqueza, dão conta somente de generalizações empíricas. Apenas teorias seriam as estruturas (formas de representação) mentais que incluem entidades teóricas, relações entre elas e relações entre elas e os fenômenos.

No mesmo estudo Brewer ainda aponta que, na visão pluralista, há muitas formas diferentes de informação no mundo (informação espacial, mecânica/causal, intencional) e diferentes formas de representação mental são necessárias para dar conta de como os seres humanos lidam com estas diferentes formas de informação.

Dos estudos de Brinck e Gardenfors (1999) entendemos que representações mentais são constructos necessários para planejamento, raciocínio e comportamento racional em geral. Para estes autores o mundo interno é consciência, cuja unidade não se dá somente no cérebro, mas na unidade funcional do organismo como situado no ambiente.

Explicam que alguns tipos de comportamento animal, como a fototaxia (atração ou repulsão à luz), são determinados por mecanismos psicofísicos que traduzem informação sobre o ambiente - não envolvem representações, são reflexos que conectam sinais ao comportamento. 
Em outros casos, os animais usam uma informação que possuem para inferências perceptuais, ou seja, adicionam informação àquela obtida pelos receptores psicofísicos. Quando há adição de informação ao input sensorial há construção de representações. Por exemplo, quando um pássaro interpreta algo como alimento, há adição de informação ao que é visto, e neste caso podem ocorrer erros.

Vejamos melhor o exemplo: um pássaro insetívoro vê um inseto se movendo e o captura como alimento; quando vê uma semente alada se movendo pode interpreta-la como alimento. Neste caso, não apenas vê a semente mas adiciona informação ao que é visto e, neste exemplo, erra.

A representação mental pode ser de algo que está presente na situação externa do organismo, como no exemplo acima, ou de algo ausente.

Esta representação de algo ausente pode ser dependente de referencial externo (como quando um gato espera um rato sair de seu esconderijo porque já o viu sair) ou independente de referente externo.

Dando outros exemplos, um mapa mental depende de se percorrer um local, mas podemos descrever um local fictício, independente de existir.

Assim o mundo interno de um organismo é formado por representações independentes somadas às dependentes de algo já percebido e mais às representações de coisas presentes.

Consistindo de representações de objetos, lugares, ações e suas conseqüências, mesmo quando as coisas não estão presentes no ambiente, o mundo interno é um intermediário entre percepção e ação pois fornece ao organismo um modelo coerente do mundo externo.

As representações são, assim, instrumentais para a intencionalidade que envolve ação, como, por exemplo, deslocar-se para uma fonte de água conhecida ou para um abrigo já utilizado.

Popper (1992: 21) também se refere a um mundo interno, distinguindo o mundo físico (das coisas materiais), o mundo psíquico (das emoções) e o mundo dos produtos intelectuais (textos, sinfonias, aviões...). 
A interação entre estes três mundos forma a realidade que pode ser compartilhada pela linguagem humana que, para Popper (1992: 32), não é apenas expressão, comunicação ou simbolismo, mas tem também função representativa por realizar proposições descritivas, e função argumentativa que põe à prova tais proposições.

Representação mental se liga à realidade e ao conhecimento. Berger e Luckmann (1990: 11) definem realidade como a "qualidade de fenômenos que reconhecemos como independentes de nossa própria volição"; e conhecimento como a "certeza de que os fenômenos são reais e possuem características específicas".

Sobre "o mundo da vida cotidiana ... tomado como uma realidade certa", alertam para as mediações "entre os universos macroscópicos de significação, objetivados por uma sociedade, e os modos pelos quais estes universos são subjetivamente reais para os indivíduos" (id. ib.: 109).

Podemos entender estas mediações no campo do aprendizado de conceitos.

Piaget e Garcia (1984: 244) reconhecem os aspectos sócio-culturais na aprendizagem de conceitos construídos sobre os objetos, mas defendem a existência de invariantes cognitivos na aquisição de conhecimento.

Para estes pesquisadores há estruturas mentais existentes lidando com conceitos e com aquisição de conhecimentos. As estruturas variáveis são as significações dadas aos objetos pelos sujeitos e sociedades. E as estruturas invariáveis refletem como os sujeitos assimilam conhecimentos construídos, ou seja, estes processos de assimilação seriam os mesmos para todos os sujeitos.

Voltando nossa atenção para esta aquisição de conhecimentos utilizamos o estudo feito por Susan Gelman (1998) para um amplo projeto de educação científica da American Asoociation for the Advancement of Science. A autora faz uma revisão de tópicos de psicologia cognitiva, em especial sobre o desenvolvimento de conceitos partindo da infância préescolar. 
Para Gelman (1998: 51) conceitos são um meio eficiente de organizar experiências. Se a criança fosse incapaz de categorizar, suas experiências seriam caóticas, com objetos, propriedades, sensações e eventos numerosos demais para serem memorizados. Portanto, as crianças formam categorias muito cedo e, com a aquisição de linguagem (carregada de conceitos) entre 1-2 anos de idade estão aptas à aquisição de conceitos.

Mas conceitos fazem mais do que organizar informações na memória. Servem para incrementar as habilidades cognitivas, como identificar objetos, formar analogias, fazer inferências que estendem o conhecimento além do já conhecido. Servem ainda para convergir elementos em direção a teorias. Assim, conceitos são como blocos construtivos para habilidades cognitivas (id. ib.: 51).

Uma dessas habilidades cognitivas, a indução, permite estender conhecimento, mas também pode trazer estereótipos. Ou seja, conceitos permitem inferência indutiva mas a inferência das crianças nem sempre é apropriada. Isto traz a questão da incorporação de teorias na cognição.

Teorias ajudam a aprender conceitos por três motivos:

- ajudam a identificar aquelas características que são relevantes para um conceito;

- indicam como similaridades podem ser computadas;

- podem influenciar como os conceitos são armazenados na memória (id. ib.: 55).

Portanto, a aquisição de conceitos pode ocorrer mais suavemente com a ajuda de teorias, mesmo quando estas teorias - aplicadas subjetivamente - vão se modificando pelas etapas de desenvolvimento, ou pelas etapas da compreensão possível dos indivíduos.

Ou seja, conceitos mentais são formados e reformados sobre conhecimentos adquiridos, muitos deles dados como conjuntos de explicações sobre os fenômenos e o mundo.

A consideração acima nos remete às possíveis interpretações ou reconstruções da teoria ecológica em diferentes sujeitos. 
Mas compreendemos da leitura de obra de Habermas (1982: 335) que teorias são discursos e que estes estão livres da coerção que afeta as atividades e não postulam informações e experiências como condição para sua constituição.

Habermas discute que discursos dependem só de linguagem, porém com sua estrutura comunicacional biunívoca onde a compreensão recíproca acerca de experiências e de proposições só ocorre quando houver uma metacomunicação referente a convergências motivacionais.

E define comunicações que expressam um conteúdo experimental objetivo como sendo afirmações (juízos declarativos), ou ainda como sendo preceitos (juízos normativos) e valorações (juízos de avaliação). Em todos estes juízos a objetividade da percepção está garantida pela estrutura, intersubjetivamente compartilhada, dos objetos da experiência possível (id. ib.: 338).

Devemos, portanto, considerar a distinção entre experiência sensorial (observação) e experiência comunicativa (compreensão) nas verificações propostas neste estudo buscando mais caminhos na cognição ambiental.

Consideramos a definição de Moore e Golledge (1976) para cognição ambiental, ou seja, o estudo da informação subjetiva, da consciência, imagens, impressões e crenças que as pessoas têm sobre os aspectos elementais, estruturais, funcionais e simbólicos dos ambientes, reais ou imaginários, físicos, sociais, culturais, econômicos e políticos.

Em outros termos, cognição é o conhecimento que surge do estímulo externo somado a toda carga de respostas comportamentais de um indivíduo. Une sensação, percepção, imaginação, memória, razão, solução de problemas, julgamento e avaliação.

E a cognição ambiental estuda as formas pelas quais os conceitos sobre o ambiente surgem da experiência, e as formas pelas quais afetam subsequente comportamento em relação ao ambiente.

Mas, além disso, na formação de representações mentais também é importante considerar as relações entre os homens e entre estes e a natureza. 
Marilena Chauí (1994), em obra paradidática, expõe que os homens constróem instituições para fixar seu modo de sociabilidade e produzem representações para explicar e compreender a vida individual, social, suas relações com a natureza e com o sobrenatural.

Mas alerta que entender as idéias como independentes é ocultamento da realidade social que se define como ideologia. Propõe o entendimento da realidade histórica e social para tornar compreensíveis as representações.

Reforçando aqui a presença da realidade social no tema da percepção, o artigo de Coeterier (1996) traz afirmações de ser a paisagem mental organizada de modo diferente da paisagem exterior, e de modo diferente para cada grupo de pessoas.

A paisagem exterior recebe atributos quando percebida pelos indivíduos. São descritos como atributos, por exemplo, o grau de unidade, modo de funcionamento, cronologia, manutenção, ordenação espacial, crescimento, base abiótica e impressões sensoriais.

Mas não há uma relação direta entre os objetos do mundo exterior e os atributos do mundo interior. Um objeto pode contribuir de formas diferentes para vários atributos, dependendo do tipo de paisagem considerada. Tampouco os atributos são simples aspectos da paisagem mental: eles representam universos de significações complexos e, muitas vezes, sobrepostos uns aos outros.

$\mathrm{Na}$ paisagem exterior, os objetos têm relações entre si. Porém, na paisagem mental, certos atributos representam essa organização exterior de diferentes pontos de vista.

Buscando pontos comuns para as diversas representações mentais do ambiente, nos voltamos para a aquisição de conhecimento e para as conexões entre conhecimento do senso comum e conhecimento científico (acadêmico). 
O conhecimento comum é mais concreto do que abstrato, mais baseado nas necessidades e nos fatos cotidianos. O conhecimento sistematizado, principalmente o científico, mais abstrato do que concreto, é relacional e se apóia em teorias gerais para explicar as inúmeras situações e fatos.

Temos, desde cedo, conhecimentos do senso comum mas também conhecimentos científicos.

Granger (1994: 16) nos lembra que a ciência está muito presente no nosso cotidiano. Os produtos da técnica que nos rodeiam estão "impregnados de pensamento científico". Além disso, temos representações do pensamento científico de fontes de divulgação como jornais, revistas, rádio, televisão. Assim formam-se muitas idéias sobre ciência e muitas crenças.

Retornamos, portanto, à idéia de elementos conceituais que são précondição para se ter crenças, tanto na comunidade científica quanto em cada indivíduo.

Tanto a produção de conhecimento (científico) como a aquisição deste conhecimento construído não se dá no vazio, mas está imersa numa concepção de mundo (Delizoicov, 1991), ou em paradigmas que podem ser aprendidos.

Sobre paradigmas, Schnitman e Fuks (1996: 291) argumentam que

“... quando se trata de transitar em situações previsíveis e conhecidas, os modelos aprendidos e incorporados socialmente funcionam com um alto grau de eficácia para ordenar a "realidade" e as ações que encaixam com ela, permitindo assim fluidez na experiência e transparência em nossas relações com essa realidade. Desse modo, os efeitos de cada queda dos velhos paradigmas em nossa prática cotidiana não se fazem evidentes; continuamos vivendo, então, como se contássemos com respostas a todas as perguntas e como se a realidade fosse algo que se possa conhecer objetivamente".

Mudanças na concepção de mundo, quedas de paradigmas, rupturas, podem não ser percebidas com clareza mas são necessárias na construção da ciência, como defendido por Kuhn (1962), e também na aquisição do conhecimento científico já construído. 
O conhecimento do senso comum possui paradigmas, usados para explicar fenômenos, que devem ser rompidos na aquisição de novos conhecimentos. E esse rompimento é possível com abertura para incertezas, para dúvidas acerca da realidade, que possam ser compartilhadas com diálogos.

Parece claro que a ausência de questionamentos, de explorações, dificulta o aprendizado, ou a aquisição de novos conhecimentos.

Abordando ensino de Física, tratando de transições no conhecimento, Delizoicov (1991) aponta que, em situações escolares, geralmente se supõe que novos conhecimentos são automática e linearmente incorporados ao pensamento.

Mas a aquisição dos paradigmas da ciência, pelos educandos, deve ocorrer "num processo de ruptura com aquele conhecimento prevalente para que seja possível a continuidade da interpretação dos fenômenos, via conhecimento produzido pela ciência e não pelo conhecimento vulgar" (id. ib. : 62).

Podemos supor, então, que todos temos conhecimentos de senso comum e, em graus variados, conhecimentos científicos sobre o ambiente.

Porém, de acordo com Habermas (1982), mesmo os graus variados de conhecimento científico podem se equivaler na técnica, no agir técnico do homem no meio.

A leitura da obra de Habermas faz considerar um sujeito social visto sob a perspectiva do poder de dispor sobre processos naturais acumulados nas forças produtivas. Havendo este sujeito social, "todos os membros da sociedade vivem, em princípio, ao mesmo nível de dominação da natureza disponível com o respectivo saber técnico" (id. ib. : 69).

Além de apontar para uma base comum entre os indivíduos de uma sociedade, Habermas aborda a incerteza face à realidade como força que acarreta novas concepções. Expõe que uma convicção, como hábito, se torna uma regra de comportamento até que fracasse no enfrentamento da realidade. No momento do fracasso, surgem dúvidas e incertezas acerca da validade das convicções correspondentes. 
"Se concebermos desta forma a função do conhecimento, como um substituto da orientação instintiva do comportamento, então a racionalidade da atividade controlada pelo sucesso mede-se pela satisfação de um interesse que, por sua vez, não pode ser nem um interesse apenas empírico, nem um interesse puro. ... O sucesso se mede pela capacidade de resolver problemas que possuem uma valoração vital e, ao mesmo tempo, um valor cognitivo" (Habermas, 1982:150).

O sucesso na resolução de problemas, a que se refere Habermas, como impulsionador da aquisição de novos conhecimentos, conduz nosso pensamento à psicologia cognitiva de Piaget centrada em processos de assimilação e de acomodação que supõe um 'fazer'.

\subsection{Construção e valorização do conhecimento científico}

Para abordar a construção e valorização da ciência no conhecimento sobre o ambiente nos detemos inicialmente na obra de Kuhn (1962).

Uma repercussão importante da obra deste filósofo e sociólogo da ciência está no desenvolvimento da concepção sobre conhecimento científico que se denomina construtivismo na qual os preceitos científicos não são dados nem têm uma existência independente dos sujeitos, mas são construções sociais, com gênese e desenvolvimento.

A concepção de Kuhn liga-se ao construtivismo social, na qual a ciência é um conjunto de práticas sociais como qualquer outro sistema, como as políticas.

Mas este autor volta-se também para a epistemologia e aponta que por meio do conhecimento construído se obtém um acesso epistêmico à realidade. Utiliza 'marco conceitual', 'esquema conceitual' e 'paradigma' indistintamente como conjuntos de elementos conceituais que são précondição para se ter crenças podendo haver aprendizagem de paradigmas.

A tese ontológica do construtivismo traz que a análise de objetos existentes no mundo não depende só dos objetos, mas também da linguagem ou do marco conceitual que se utiliza porque depende da noção de objeto na linguagem ou no marco conceitual utilizado. 
Por sua vez, a tese epistemológica do construtivismo é que o conhecimento científico depende do mundo e dos recursos conceituais e metodológicos da comunidade científica.

Porém, mesmo reconhecida como prática social, onde Kuhn ainda nos fala de interpretabilidade mais que em tradução de paradigmas, a ciência é muito valorizada no mundo atual.

Procurando explicar esta valorização da ciência, Granger (1994: 46) nos traz três traços característicos da visão científica:

- a ciência é visão de uma realidade (é uma representação abstrata, mas se apresenta como representação do real);

- a ciência visa a objetos para descrever e explicar, não diretamente para agir;

- a ciência se preocupa constantemente com critérios de validação.

Granger conclui que "a ciência é uma das mais extraordinárias criações do homem, ao mesmo tempo pelos poderes que the confere e pela satisfação intelectual e até estética que suas explicações Ihe proporcionam. No entanto, ... nossos conhecimentos científicos são necessariamente parciais e relativos" (id. ib.: 113).

Como vimos, a ciência é considerada representação abstrata e não envolve necessariamente ações e escolhas de valor. John Ziman (1986) nos lembra que, fora do ambiente acadêmico, a ciência é recurso para tecnologia nova, não para o puro progresso do conhecimento.

Mas é atividade racional acima de tudo. E de acordo com Newton Costa (1997: 35) esta racionalidade reside nos sistemas conceituais, mas também pressupõe uma lógica dedutiva, ou, simplificadamente, o processo de pensar do geral para o particular.

Porém as inferências que fazemos na ciência e na vida quotidiana não se enquadram apenas entre as dedutivas. Necessitamos efetuar inferências que não são dedutivas, tais como a indução por simples enumeração, a analogia, a inferência estatística e o método hipotéticodedutivo. 
Assim, a racionalidade em ciência deve ser conceitual, dedutiva, indutiva e crítica, ou seja, depende da capacidade de conceituar, de julgar (em particular, de criticar) e de inferir. Na ciência, captamos e explicamos o real via conceitos e redes conceituais, que edificamos. Por essa rota, obtemos as leis, hipóteses e teorias. Elas nos permitem ordenar o universo, por meio de explicações, revisões e sistematizações (Costa, 1997)

Também para Jacob Bronowski (1985) o homem tem capacidade de emitir sentenças cognitivas, capacidade de exercitar o conhecimento e a imaginação (criação de imagens na mente). $E$ a ciência tenta representar o mundo como um sistema formal, mas não há permanência para os conceitos científicos porque eles são apenas nossa interpretação dos fenômenos naturais.

No entanto, o conhecimento científico é valorizado.

Popper (1992: 17) considera o conhecimento das ciências naturais como o melhor e o mais importante que possuímos porque 1- parte dos problemas práticos ou teóricos; 2- é uma procura da verdade, de teorias explicativas objetivamente verdadeiras; e 3- o conhecimento não é uma procura da certeza.

Ou seja, o conhecimento científico, o saber científico, é sempre hipotético, conjectura, mas é verdadeiro "quando o fato por ele descrito está de acordo com a realidade" (id. ib.: 18).

Em resumo, e em visão positivista, a natureza do conhecimento científico é a explicação de fenômenos naturais e de fenômenos produzidos pelo homem através da (busca de) formulação de leis ou teorias.

O método para se alcançar o conhecimento científico de fenômenos (naturais) é, primariamente, experimental, consistindo na observação (dos fenômenos), em medidas de grandezas envolvidas (ou experimentação com medidas) e no relacionamento entre essas grandezas para se descobrir as leis que regem os fenômenos pesquisados. 
Porém a observação de fenômenos não é isenta. Ela é precedida por teorias (conhecimentos, crenças) que dependem do ambiente social, das características individuais, das habilidades perceptivas do observador, e do paradigma existente.

Paradigma se refere ao conjunto de teorias, métodos, problemas considerados como relevantes e soluções aceitáveis por consenso entre os cientistas. Acrescenta-se que o consenso é social e não está isento da história e da economia.

Assim a visão positivista que delineamos acima tangencia 0 racionalismo dialético de Bachelard (1986), o contextualismo de Kuhn (1962) e o anarquismo epistemológico de Feyerabend (1985) que aponta para uma visão dialética e construtivista da ciência.

Para Feyerabend a ciência é uma forma de ideologia (conjunto de idéias que legitimam ou reproduzem a ordem estabelecida), de conhecimento, como outras, se aproximando do mito e tendo a linguagem como elemento de grande importância, levando à necessidade de liberdade e criatividade individuais.

Nesta visão construtivista do conhecimento o sujeito constrói significados ou esquemas mentais perante situações novas. Mas constrói a partir do que já conhece, a partir das concepções que já tem, concepções estas também ligadas a ideologias, a mitos, e dependentes da linguagem. É uma construção social, talvez daí derive 0 interesse do anarquismo epistemológico de Feyerabend para novas compreensões.

Mas quando pensamos sobre conhecimento científico devemos ir além dos cientistas. Porque, além da possibilidade da construção deste conhecimento perante situações novas, analisando-se criticamente a bagagem social, a ciência é ensinada.

No ensino de ciência colocam-se situações novas que são interpretadas pelos aprendizes à luz de suas concepções existentes e, como estratégia de ensino, questionam-se tais interpretações, inventando-se ou introduzindo-se novos conceitos ou conceitos científicos já firmados. 
No entanto devemos nos perguntar para quê introduzimos conceitos. Se reconhecemos como ideologia os conceitos científicos da educação científica escolar, nos perguntamos para quê serve a ruptura, o conflito de idéias necessário para a reorganização de conceitos, que é apregoado pelo construtivismo. Por fim, para quê consideramos as concepções nãocientíficas como alternativas.

Pois se a ciência resolve problemas, é o que importaria aos alunos: aprender processos para a resolução de problemas, criar conhecimento em situações novas. Se introduzimos conceitos científicos já firmados é porque nos importa ensinar a ciência, como a linguagem e o mito, como herança da sociedade que a retém.

O ensino construtivista que encontramos apregoado e utilizado torna o aluno receptivo a teorias propostas por cientistas, dando-Ihe um acréscimo na herança cultural. Talvez, colocando-o no processo de resolução de problemas, dê-Ihe capacidade para analisar e criticar tal herança.

Assim a análise crítica é o grande ganho do ensino construtivista. Mas a condução deste ensino pode remeter ao empiricismo, isto é, ao 'fazer' situacional, pois a resolução de problemas, ou a criação de conhecimento em situações novas, também remete ao empiricismo, colocado como tão contraditório ao construtivismo que pretende ampliar a bagagem conceitual dos indivíduos.

Cobern (1996) afirma que mudanças conceituais podem ser mais plausíveis para estudantes quando convidados a um discurso sobre as questões importantes da vida, sobre as várias respostas, e sobre o que a ciência tem para contribuir com as questões comuns para uma vida mais cheia de significados.

Ou seja, mudanças conceituais fazem pouco sentido quando os conceitos científicos são apresentados com pouco significado para a maioria dos estudantes. Cobern, no mesmo trabalho, define significado como amplitude e força dentro da visão de mundo dos estudantes.

Tal 'visão de mundo' dá fundação não-racional para o pensamento, emoções e comportamento; dá pressuposições sobre o mundo e sobre o conhecimento que cada indivíduo considera válido e importante. 
Cobern (1996) adapta o lógico-estruturalismo da antropologia cultural para a pesquisa em educação para a ciência. Afirma que o poder do modelo lógico-estrutural está na estrutura composta, interrelacionada, de categorias universais.

Melhor explicando, tais categorias universais são as que carregam pressupostos fundamentais sobre a existência e sobre o ser, e se listam como: Eu, Outro, Classificação, Relação, Causalidade, Tempo e Espaço.

Assim, Cobern trata de visão de mundo compatível com a ciência, não de visão de mundo científica, e alerta para diferenças cognitivas fundamentais entre as pessoas mas sem sugerir que toda diferença cultural ou social é resultado da visão de mundo diferente.

Por fim, considera importante criar atmosfera de aprendizado que discuta pontos de vista pessoais para que haja possibilidade de apreensão, de aceitação como válido do conceito que compreendemos através do pensamento, podendo, então, haver mudança conceitual.

Para melhor entendimento do trabalho de Cobern (1996), indicamos a sua exemplificação de pressuposições de visão de mundo na explicação de fatos:

explicação mágica - forças do mundo mística - mistérios inexplicáveis espiritualista - seres de outros mundos parapsicológica - força humana inexplicável racional - uso da razão ou do senso comum metafísica - separação do corpo físico pseudocientífica - uso de conceitos científicos com erros científica - uso de mecanicismo, reducionismo, objetivismo e empiricismo

Na mesma temática, Stinner (1995) também defende uma educação científica mais humanística com a contextualização de itens a serem ensinados, ensino temático, assuntos contemporâneos de interesse e estórias que podem diminuir a distância entre conhecimento científico e senso comum.

Para Marcos Reigota (1995) o senso comum que se tem sobre um determinado tema, onde se incluem também os preconceitos, ideologias e características específicas das atividades cotidianas (sociais e profissionais) das pessoas, é uma representação social que tem função de contribuir para os processos de formação de condutas e de orientação das comunicações sociais. 
Esta definição de senso comum pode se confundir com ideologia, ou seja, com os conceitos e valores particulares de um grupo social passados a todos como se fossem universais (Severino, 1994: 117).

Preferimos não ficar neste campo, mas no do conhecimento que, também segundo Severino, em sentido geral, é "a capacidade dos homens de encontrar e/ou atribuir um significado para os elementos que caem em seu campo de experiência, mediante a utilização de conceitos (como mediadores)" (id. ib.: 82).

Esta 'atribuição de significados' nos interessa por estar ligada a atitudes.

Ma e Bateson (1999) examinaram testes educacionais (escolares) para estabelecer se há uma relação entre atitude para ciência e atitude para o ambiente.

Encontraram que estudantes com uma atitude favorável para o ambiente também mostram atitude favorável para a ciência. Isto implica que educadores ambientais podem predizer atitudes para o ambiente de atitudes para a ciência. As relações também indicam que tais atitudes são influenciáveis uma em relação à outra.

Na mesma linha de estudo, Cottrell e Graefe (1997) examinaram comportamento ambiental responsável - geral e específico. Encontraram que comprometimento verbal e conhecimento percebido de ecologia são preditores significativos de comportamento ambiental responsável geral. $\mathrm{O}$ comportamento específico parece ser mais situacional.

Abordando justamente a questão ambiental e o estudo de ciências Koff (1995) julga como importante para o ensino de ciências o domínio da matéria (conhecimento de fenômenos naturais e produzidos pelo homem) e o acompanhamento das descobertas científicas, com relacionamentos, implicações e análise crítica.

$\mathrm{Na}$ educação ambiental coloca como importante relacionar processos naturais com processos sociais, culturais e históricos, reconhecer limites e potencialidades da natureza e ter domínio da matéria. E, em ambos os temas, ciências ou educação ambiental, considera importante o ensino ou conhecimento do método científico, simplificadamente sendo a escolha do problema, a realização de verificações, análise e discussão. 
Por fim, Koff, na mesma obra que consultamos, propõe avaliar o desempenho do aluno na aplicação de conceitos ecológicos através dos comportamentos apresentados em uma determinada situação. Os comportamentos portanto desejáveis para os educandos são:

delimita a área de estudo; - registra a presença de seres vivos e identificaos, descreve ações e reações, identifica relações entre os organismos; respeita os seres vivos; - exemplifica conceitos ecológicos; - tira conclusões.

Em outra vertente de educação ambiental encontramos um estudo de Matt Sanger (1997) abordando o senso de lugar que se refere à intimidade baseada na experiência - com os processos naturais, comunidade e história de um lugar.

De acordo este pesquisador os indivíduos adquirem senso de lugar através de conversas com outros indivíduos daquele lugar, trocando estórias sobre a terra e seus habitantes, e através da educação, mas não a educação que predomina no sistema educacional atual.

Explica que atualmente as escolas dão aos estudantes a linguagem, metáforas e visões de mundo como indivíduos independentes, sem auxiliálos a estarem conectados (portanto responsáveis) a um lugar, a terra e às comunidades que lá habitam.

Além do exposto, Sanger (1997) considera o senso de lugar importante para a qualidade ambiental e critica o uso de livro-texto que subjuga formas locais de conhecimento e encobre a conexão das pessoas por meio de tradições orais. Livros-texto dão valor a exemplos e fatos gerais, nacionais e abstratos, marginalizando o que os estudantes apreendem de suas próprias experiências de lugar, família e comunidade.

Em contraste à palavra escrita, fixa, abstrata e individualizada, a comunicação oral é situacional, participativa, comunal, intersubjetiva e física. A subordinação da comunicação oral à escrita, ou da estória ao texto, pode ajudar a tornar os estudantes alienados de seu lugar e dos processos que os conectam a ele.

Num meio termo entre uma educação ambiental voltada para a ciência e outra voltada para aspectos sociais e afetivos, encontramos o texto de Enrique Leff que trata de uma epistemologia ambiental. 
Para Leff (2001) o ambiente é uma categoria sociológica (e não biológica). Neste sentido, o ambiente do sistema econômico está constituído pelas condições ecológicas de produtividade e regeneração dos recursos naturais, bem como pelas leis termodinâmicas de degradação de matéria e energia no processo produtivo.

Por conseguinte, o saber ambiental é um saber sobre esse campo externalizado pela racionalidade econômica, científica e tecnológica da modernidade; "mas, por sua vez, conota os saberes marginalizados e subjugados pela centralidade do lógos científico" (id. ib.: 159).

O saber ambiental, como propõe Leff, geraria um conhecimento científico objetivo para solução de problemas ambientais pontuais, organização interdisciplinar, novas significações sociais, novas formas de subjetividade e de posicionamento ante $o$ mundo. Pretende integrar conhecimentos e valores e critica os projetos de comunicação e informação ambiental cujo fluxo indiferenciado de dados tem o simples propósito de gerar consensos sociais.

O estudo de Robert Szaro e colaboradores (1998) tem visão mais ampla sobre a informação científica ambiental. Resume que mudanças na expectativa pública e aumento no envolvimento público têm provocado alterações nas políticas e práticas tradicionais incluindo a necessidade de informação científica como fundamento para decisões sobre manejo de recursos.

Mas Szaro et al. (1998) identificam falhas na base científica necessária para a implementação de manejo de ecossistemas, como: desconhecimento de ecologia em múltipla escala e da dimensão humana do uso de recursos naturais; escassez de estudos sobre múltiplas espécies, de monitoramento e avaliação, de reprodução de boas práticas, de estudos socioeconômicos e de valoração; falta de desenvolvimento de tecnologias de restauração ecológica, de quantificação de incertezas e avaliação de riscos, de modelagem e de processos de manejo adaptativos. 
Os autores acima concluem com a necessidade de assistência técnica e treinamento para administradores e sujeitos envolvidos em decisões; o desenvolvimento de tecnologia e de estudos; o desenvolvimento de mecanismos de coordenação e cooperação incluindo pesquisa interdisciplinar, agendas regionais, informação do público e transferência de tecnologia.

\subsection{Conhecimento científico sobre o ambiente}

Robert H. Peters (1990: 12), fazendo uma crítica à ecologia, relata que a ação ecológica de pressão política nos anos 60 e 70 teve sucesso em avançar a conservação. Porém, como a teoria ecológica é frágil, esta ação não teve base científica e os ecologistas passaram a falar em território não familiar onde não tinham autoridade.

Assim, o papel político dos ecologistas passou cada vez mais para não-cientistas. Isto, de alguma forma, é bom. Encoraja a separação entre política e ciência e talvez a concentração dos esforços dos cientistas no desenvolvimento de ferramentas científicas para a ação ambiental.

Para Peters (1990: 17) "a ecologia procura predizer as abundâncias, distribuições e outras características dos organismos na natureza". Portanto a teoria ecológica deve permitir a avaliação de ecossistemas e a avaliação das modificações causadas pelo homem no meio para auxiliar efetivamente na tomada de decisões que levem a intervenções menos destrutivas ou mais construtivas.

Em 1986 o Comitê para Aplicações da Teoria Ecológica nos Problemas Ambientais do Conselho Nacional de Pesquisa norte-americano já relatava que, para manejar os efeitos das manipulações ambientais, nós devemos ser capazes de predizê-los sendo necessários estudos mais pontuais, com limites temporais, espaciais e ecológicos, com o objetivo de dar-nos informações para a tomada de decisões (National Research Council, 1986). 
Deveriam ser analisados o início e término dos efeitos das manipulações sobre o ambiente, a área em que ocorreriam, a existência ou não de barreiras naturais para tais efeitos, a existência ou não de processos físicos ou biológicos que levam os efeitos a outras áreas e os componentes do ecossistema considerado que seriam afetados.

Em vista da destruição de ecossistemas, a capacidade de predição da teoria ecológica é uma necessidade que resultou na conservação biológica e manejo ambiental como novos ramos da ecologia e da biogeografia (Gilbertson et al., 1990).

A crítica à capacidade preditiva da teoria ecológica reside na falta de unidades para formação de modelos.

O ambiente é complexo, mas sua subdivisão e classificação é necessária para medições, manejo, proteção, desenvolvimento, mudanças, e planejamento.

Preocupado com unidades ambientais, Haber (1994: 50) propôs ao planejamento e manejo ambiental linhas de estudo e métodos específicos derivados da teoria de ecossistemas e da ecologia da paisagem.

Para Haber (1994) conceitos de ecossistema e ecótopo podem ser muito práticos se bem definidos. Ecossistema tem seu lugar na hierarquia de níveis organizacionais - representa o primeiro nível onde fatores vivos e não-vivos se integram -, e ecótopo é o menor componente espacial homogêneo de uma paisagem, ou melhor, é um ecossistema concreto em uma localidade definida.

Os conceitos ecótopo e biótopo (localização de uma comunidade biótica) podem coincidir espacialmente, mas a unidade ecótopo tornaria o ecossistema mais operacional para planejamento.

Porém este planejamento deve estar assentado na teoria ecológica que implica, a nosso ver, manutenção da diversidade biológica como seu paradigma.

Para Pimm e Gilpin (1989), em obra que trata das perspectivas em teoria ecológica, há 4 causas principais da perda de diversidade:

1) perda de habitats por fragmentação, redução, poluição e degradação;

2) matança de plantas e animais pelo homem;

3) introdução de espécies estranhas em um dado habitat; 
4) efeitos secundários da extinção: a extinção de uma espécie causando a extinção de outra.

Estes autores explicam que a perda de habitats é a causa mais importante. Mesmo quando aparentemente grandes extensões de terra são protegidas, estas áreas podem estar isoladas de outras e cada fragmento pode ser pequeno demais para manter populações viáveis.

Um fragmento é diferente do habitat contínuo do qual fazia parte e efeitos de borda são considerações importantes porque uma borda pode permitir a penetração de fatores bióticos ausentes no sistema total e também pode haver mudanças abióticas na zona da borda.

Havendo fragmentação de habitats, precisamos também conhecer a dinâmica de movimentação das espécies.

Para o caso de redução, precisamos ser capazes de predizer, a partir de índices de espécies mensuráveis e dinâmicos, que efeitos surgirão no meio ambiente e nas espécies.

Em particular, precisamos relacionar área com tamanho de população e este com probabilidade de extinção.

Se conhecermos a probabilidade de extinção das espécies em várias configurações espaciais de habitats, seremos capazes de decisões mais racionais no planejamento e manejo ambiental.

$\mathrm{Na}$ teoria ecológica há dois tipos de processos que causam extinção: aqueles associados com acidentes demográficos, que dependem fortemente do tamanho populacional, e aqueles associados com variação ambiental, que dependem menos do tamanho populacional.

As características populacionais - como rapidez de crescimento, tempo de vida dos indivíduos - interagem com estes dois fatores resultando em padrões para ameaças de extinção.

Para acidentes demográficos somente, o tempo para extinção aumenta rapidamente com o tamanho da população. E, para um dado tamanho populacional, a variação ambiental reduz o tempo para extinção abaixo do esperado de acidentes demográficos agindo sozinhos em um ambiente invariável. 
Assim retomamos que o planejamento ambiental deve considerar a teoria ecológica que implica busca de conhecimentos para a manutenção da diversidade biológica dentro de conjunturas de destruição e fragmentação de habitats.

É uma posição que conduz a análise de ações de preservação ambiental sob o foco da preservação da dinâmica dos ecossistemas.

Além disto, resumimos, dos inúmeros estudos analisados, que podemos concluir com a distinção de modelos mentais, do mundo e portanto do meio ambiente. Distinção feita pela realidade objetiva e subjetiva que cerca os indivíduos tornando-os únicos, mas também que permite agrupa-los, por oferecer elementos comuns a grupos de indivíduos.

Podemos ainda concluir que elementos comuns ocorrem também entre grupos, no que reside as possibilidades de diálogo entre modelos mentais de ambiente que investigamos neste trabalho.

\section{PROTEÇÃO AMBIENTAL EM EMPRESAS}

A história da proteção ambiental no Brasil não é das mais significativas. No período colonial houve exploração inconseqüente dos recursos naturais e a industrialização urbana, que começou na década de 30 e se acentuou após a II Guerra Mundial, rapidamente trouxe deterioração ambiental.

Indústrias foram instaladas de maneira indiscriminada, sem controle de poluentes, muitas vezes com equipamentos de segunda mão agravando a poluição. Sua concentração em algumas regiões do país causou também - agravamento da pobreza urbana com conseqüente aumento dos problemas ambientais urbanos.

De acordo com Baer e Mueller (1996: 333) "a política de industrialização para substituição de importações - ISI - provocou uma rápida urbanização. Enquanto em 1940 a população urbana era de 31\%, em 1950 essa taxa havia crescido para 36\%, em 1965 para 50\% e em 1989 para $74 \%$ ". Mas o aumento populacional não foi acompanhado por infraestrutura apropriada.

A tabela a seguir (Tabela 1) acrescenta informações sobre a distribuição da população urbana e rural no Brasil. 
Tabela 1 - Demografia do Brasil em 1991, 1997 e 2000

\begin{tabular}{l|l|l|l|l|l} 
ano & pop. total & urbana & $\%$ & rural & $\%$ \\
\hline 1991 & 146.825 .475 & 110.990 .253 & 75,6 & 35.835 .222 & 24,4 \\
\hline 1997 & 159.886 .000 & 120.665 .964 & 75,47 & 39.220 .036 & 24,53 \\
\hline 2000 & 169.590 .693 & 137.755 .550 & 81,23 & 31.835 .143 & 18,77
\end{tabular}

Fontes: Censo de 1991, Estimativa para 1997 e Censo de 2000, IBGE (Fundação Instituto Brasileiro de Geografia e Estatística)

No campo a situação não foi melhor. O desenvolvimento agrícola brasileiro foi horizontal, pautado em desmatamentos e queimadas e posteriormente dependente de equipamentos e insumos que desconsideraram as características do solo.

Analisando os setores do desenvolvimento industrial brasileiro, Baer e Muller (1996: 334) registram mudanças consideráveis em quatro décadas. Houve acentuado declínio das indústrias têxteis e de produtos alimentícios, e rápida expansão das indústrias de equipamentos de transporte, de equipamentos elétricos e de produtos químicos, incluindo produtos farmacêuticos, de higiene pessoal e de plásticos.

Em algumas nações do mundo, incluindo o Brasil, entre o século XIX e os anos de 1970, surgiram preocupações com a conservação da natureza. Legislações específicas, criação de parques naturais, estabelecimento de associações civis e realização de conferências internacionais são as principais manifestações do ecologismo daquele período (Acot, 1990).

No Brasil a preocupação com a qualidade ambiental surgiu ligada ao saneamento básico e à expansão urbana. Destaca-se o Código das Águas, de 1934, que aborda a geração de energia elétrica, o controle de enchentes e o abastecimento público.

No Estado de São Paulo, a Lei o 2182 de 23/7/1953 instrui o controle de poluição das águas e é reforçada pela Lei oo 3068 de 14/3/1955 que cria o Conselho Estadual de Controle da Poluição das Águas.

No nível federal, o Decreto o 49974-A de 21/1/1961, denominado Código Nacional da Saúde, traz a obrigação das indústrias de promoverem tratamento adequado de resíduos. 
Mas somente em 1973 foi criada a Secretaria Especial do Meio Ambiente (SEMA), subordinada ao Ministério do Interior e tendo como função principal estabelecer normas de proteção ambiental em meio a políticas desenvolvimentistas.

Nos dois anos seguintes, o Estado de São Paulo organizou seu principal órgão ambiental - a CETESB - e o Rio de Janeiro fundou a FEEMA (Fundação Estadual de Engenharia do Meio Ambiente).

Nas décadas de 1970 e 1980 ocorreram manifestações da sociedade sobre danos ambientais mas a política ambiental brasileira foi fortalecida somente em 1981 com a aprovação da Lei 6.938 que estabeleceu a Política Nacional do Meio Ambiente.

O objetivo desta política é promover a preservação, recuperação e melhoria da qualidade ambiental de forma consistente com o desenvolvimento econômico e a segurança nacional.

O CONAMA (Conselho Nacional do Meio Ambiente), instituído pela Política Nacional de Meio Ambiente, composto por segmentos representativos dos poderes públicos e da sociedade civil, divulgou em 1986 a Resolução que introduziu a variável ambiental na alocação de recursos públicos e privados. Aquela Resolução estabeleceu os Estudos de Impacto Ambiental - EIAs - para empreendimentos diversos.

No nível internacional, após a Conferência das Nações Unidas para o Meio Ambiente realizada em Estocolmo no ano de 1972, e especialmente durante a década de 1980, a questão ambiental foi abordada na estrutura institucional de vários países industrializados como EUA, Japão e alguns países europeus. A Constituição brasileira de 1988 também contempla preocupações ambientais.

Mas não se pode pensar que após estes movimentos legislativos surgiu enorme incremento de condutas cautelosas com o meio ambiente.

Assim a década de 1990 assiste à criação, mobilização e principalmente institucionalização nas Organizações Não-Governamentais para conservação ambiental e desenvolvimento sustentável.

As políticas ambientais públicas são de âmbito preventivo e curativo mas de eficácia duvidosa pela demanda de mecanismos fiscalizadores que acabam por ser falhos. 
Isto acarreta um aumento da pressão de movimentos ambientalistas em direção a mecanismos de proteção ambiental de responsabilidade dos agentes poluidores ou degradadores.

Esta pressão segue tendência internacional pois, após o crescimento econômico mundial no período pós-guerra, começaram a surgir críticas à maneira como as sociedades enfrentavam os problemas ambientais que surgiram com a expansão agrícola e, especialmente, com a industrialização.

Afora os problemas de degradação ambiental, surgiram, na década de 70-80, dilemas econômicos sobre níveis de crescimento, escassez e uso de recursos naturais, e sobre desenvolvimento e transferência de tecnologia.

De acordo com Caporali (2000)

"o resultado de tal quadro de dilemas foi a emergência de duas concepções concorrentes: uma, que se convencionou chamar de "neoliberalismo", que atuava predominantemente sobre a contenção de custos nas diversas economias, impondo lógicas de austeridade; outra, que ainda busca caminhos práticos, inspirada na tradição institucionalista da teoria econômica, e que ficou conhecida como desenvolvimento sustentável".

A corrente do desenvolvimento sustentável busca combinar os mecanismos de correção econômica com medidas de controle administrativo e mantém o processo decisório pactuado entre Estado, empresas e organizações da sociedade civil.

Para esclarecer o conceito de desenvolvimento sustentável ou sustentado, indicando sua amplitude possível e aplicabilidade, trazemos o exemplo do programa "Seattle Sustentável", extraído de texto de Alan Atkisson (2000).

Em 1990 instalou-se um fórum de cidadãos em Seattle, EUA, para discutir a aplicação do conceito de desenvolvimento sustentável aos problemas ambientais, sociais e econômicos que afetavam ou afetariam o bem estar da cidade a longo prazo.

Aquele fórum também se reuniu para pensar como poderia ser medido o alcance desse objetivo de desenvolvimento sustentável, apresentado conforme o relatório "Our Common Future" da Comissão Brundtland de 1982, no qual se define desenvolvimento sustentável como aquele capaz de "suprir as necessidades do presente sem comprometer a 
capacidade das futuras gerações suprirem as suas próprias necessidades".

O grupo de Seattle definiu sustentabilidade como um processo de "saúde e vitalidade ambiental, cultural e econômica a longo prazo". Sua meta era recomendar indicadores que atingissem quatro critérios gerais estabelecidos pelos organizadores.

Os critérios definidos para os indicadores foram:

- refletir as tendências fundamentais da saúde cultural, econômica e ambiental a longo prazo;

- ser estatisticamente mensuráveis, com dados disponíveis há uma ou duas décadas, de preferência;

- ser atraentes para a mídia local, e

- ser compreensíveis para as pessoas comuns.

Nesta nossa intenção de trazer exemplos para o conceito de desenvolvimento sustentável, apontamos os seguintes itens, em grupos, que foram selecionados como indicadores pelo fórum de Seattle:

\section{Meio ambiente}

Saúde de áreas inundadas

Biodiversidade

Erosão do solo

Superfície impermeabilizada na cidade

Qualidade do ar

Áreas abertas

\section{População e Recursos}

Taxa de crescimento populacional

Consumo residencial de água

Geração e reciclagem de resíduos sólidos

Prevenção da poluição e uso de recursos renováveis

Área agrícola

Uso de energia renovável e não renovável

\section{Economia}

Porcentagem de emprego concentrado nos dez maiores empregadores

Desemprego real

Distribuição da renda pessoal

Despesas com assistência médica

Recursos para habitação

Crianças vivendo na pobreza

Capital comunitário 


\section{Juventude e Educação}

Adultos alfabetizados

Conclusão do segundo grau

Diversidade étnica dos professores

Educação artística

Envolvimento voluntário nas escolas

Delinqüência juvenil

Jovens envolvidos em serviços comunitários

\section{Saúde e Comunidade}

Equidade na justiça

Recém-natos de baixo peso

Taxa de hospitalização infantil por asma

Participação dos eleitores nas eleições primárias

Utilização da biblioteca e centro comunitário

Participação pública nas artes

Atividade de jardinagem

Boa vizinhança

Qualidade de vida perceptível

Podemos ver que são indicadores amplos e assentados não apenas na realidade física mas também na realidade social da comunidade.

Os dilemas econômicos que levaram à conceituação mundial de desenvolvimento sustentável levaram também à consideração dos recursos ambientais como sendo estoque de capital. $\mathrm{O}$ problema que surge desta concepção é a quantificação do capital natural (dos recursos naturais).

A valoração dos recursos naturais, conforme Lanna (1995), passa pelo valor de uso (valor derivado do uso do recurso para a sociedade), pelo valor de opção de uso (se refere ao uso potencial do recurso), pelo valor de existência (se refere à opção de não-utilização do recurso), e pelo valor intrínseco do ambiente (que implica direitos a todos os seres vivos).

$\mathrm{Na}$ atividade econômica produtiva, os problemas ambientais, atingindo terceiros e as gerações futuras, são considerados como externalidades das diversas instituições econômicas. 
Assim o objetivo de se procurar pela quantificação monetária ou valoração dos recursos naturais é internalizar o valor da degradação ambiental nos custos dos agentes degradadores ou poluidores, o que pode resultar em perda de produtividade e competitividade até inviabilizando o crescimento econômico.

Está claro o dilema econômico, especialmente para economias não estáveis, mas não se pode desconsiderar a equidade social, o direito de todos à saúde ambiental, cabendo ao poder público a função de gestão ambiental fundamental.

Nunes (1996: 44) define gestão ambiental como gerenciamento de recursos naturais e elenca como iniciativas do Poder Público no planejamento ambiental, mas também social e político, a educação, o desenvolvimento sustentável, o impedimento de ações egoístas e a distribuição de riqueza.

Documentos internacionais têm pressionado por respostas de todas as facções das sociedades. A Agenda 21 é exemplo desta pressão por mecanismos de proteção ambiental.

Aprovada durante a Conferência das Nações Unidas sobre Meio Ambiente e Desenvolvimento - CNUMAD - realizada no Rio de Janeiro em 1992 com a participação de 178 países, a Agenda 21 é um plano de ação para alcançar os objetivos do desenvolvimento sustentável e consolida diversos relatórios, tratados e protocolos anteriores.

José Carlos Barbieri (1997: 64) explica que a Agenda 21 conclama as empresas e suas entidades "a reconhecer o manejo do meio ambiente como uma das suas mais altas prioridades e como fator determinante do desenvolvimento sustentável".

Para o fortalecimento da indústria e do comércio com vistas ao desenvolvimento sustentável, a Agenda 21 estabelece dois programas: a promoção de uma produção mais limpa e promoção da responsabilidade empresarial. 
Produção mais limpa significa aumentar a eficiência da utilização de recursos, inclusive aumentando a reutilização e reciclagem de resíduos e reduzindo a quantidade de despejos de resíduos por unidade produzida. E responsabilidade empresarial significa vigilância no manejo e utilização dos recursos.

Barbieri (1997: 68) reforça que, além de atender os requisitos legais a que está sujeita, a empresa deve se preocupar em alcançar objetivos econômicos compatíveis com padrões sustentáveis de desenvolvimento, pelo menos com ganhos de produtividade através da prevenção da poluição.

Mas também reconhece que, a longo prazo, é o nível de conscientização da sociedade que dará resultados mais promissores de proteção ambiental e que a curto prazo é necessário impedir a degradação ambiental emergente através de instrumentos de comando e controle e de mecanismos administrativos e judiciais.

Comune (1994: 52) acrescenta que o poder público "pode intervir na qualidade do meio ambiente por meio da imposição de um sistema de normas que regulamentem as atividades dos agentes provocadores da deterioração".

As normas impostas podem ser, basicamente, de três tipos:

a) normas de qualidade do meio ambiente - que se referem à qualidade média do meio receptor da poluição e à quantidade máxima de poluição aceitável neste meio;

b) normas de despejo - que incidem nas emissões das atividades poluentes;

c) normas de produtos finais - que procuram regulamentar a poluição gerada pelas características dos produtos finais.

Além de políticas públicas de ordenação e fiscalização e de mecanismos de auto-regulação, existem os chamados instrumentos de mercado para propiciar proteção ao ambiente.

Estes instrumentos de mercado podem ser divididos em dois grupos básicos: cobrança por "serviços" prestados e compensação por "serviços" recebidos. 
No primeiro grupo incluem-se os serviços do órgão ambiental responsável, como licenciamentos e cobrança de taxas sobre produção (extração) de matéria-prima. São instrumentos que servem como fonte de receita ao órgão ambiental e também para direcionar a exploração dos recursos naturais.

O segundo grupo compreende as transferências de recursos financeiros a agentes que promovem a conservação (Lopes et al.,1996).

Os instrumentos de incentivo econômico, ou de mercado, procuram empregar preços, taxas e subsídios para que os agentes econômicos façam uso eficiente dos recursos naturais, mas claro que deve haver monitoramento por parte das autoridades e da sociedade e não simples cobrança.

Abordando mecanismos de auto-regulação Dália Maimon (1994: 122) ressaltava que a maioria das empresas se concentrava em "adaptação à regulamentação ou exigência do mercado, incorporando equipamento de controle de poluição nas saídas, sem modificar a estrutura produtiva e o produto".

Ou seja, a adoção de um comportamento pró-ativo integrando a função ambiental ao planejamento estratégico da empresa não se verificava, sendo que o princípio fundamental para desenvolvimento sustentável é de prevenir a poluição, selecionando matérias-primas, desenvolvendo novos processos e/ou produtos.

Em trabalho anterior, Ricardo Neder (1992), sondando um grupo de 48 grandes indústrias, verificou que, para a indústria brasileira, a legislação era a motivação principal para controle de emissões, resíduos e efluentes.

A negociação com as autoridades se concentrava sobre os meios técnicos de controle da poluição sem questionamento sobre o modelo de industrialização, tecnologias utilizadas ou localização.

Por tais assertivas, Layrargues (1998) questionou se os empresários estariam de fato em um processo de transição ideológica, assumindo sua responsabilidade com a melhoria da qualidade ambiental, ou se estariam realizando uma apropriação ideológica do discurso do outro, para fins de manipulação e controle da opinião pública. 
Realizou uma análise de discursos empresariais, entre 1991 e 1995, e considerou que não foi devido à consciência ecológica, mas sim à consciência econômica, que o setor empresarial adjetivou-se de "verde".

Assim estimou que se trata de apropriação ecológica e não transição ideológica porque a lógica operacional permanece sendo a do desenvolvimento convencional, e não do desenvolvimento sustentável.

Do lado empresarial, vemos que grupos de indústrias têm lançado princípios e prêmios procurando incentivar ações de melhoria ambiental.

A Federação das Indústrias do Estado de São Paulo instituiu em 1995 o Prêmio FIESP de Mérito Ambiental que objetiva distinguir e homenagear, anualmente, a empresa industrial, extrativa, manufatureira ou agro-industrial que mais se tenha destacado na implementação de projeto ambiental vinculado com o processo produtivo.

Utiliza como critérios de avaliação:

a) institucionalização de sistema de gestão e auditoria ambiental na empresa;

b) otimização do processo de produção, quanto aos balanços de massa e de energia, com redução de geração de efluentes líquidos e gasosos, e de resíduos sólidos, incluindo a demonstração do menor uso possível de recursos naturais não renováveis;

c) utilização das melhores tecnologias disponíveis para prevenção e controle da poluição, incluindo o monitoramento e a destinação dos resíduos e a descrição de ações efetivas de prevenção à poluição;

d) apresentação de resultados obtidos com a implementação de medidas de melhoria, incluindo relação custo-benefício, benefícios ambientais, investimentos realizados e lucros;

e) integração e relacionamento harmonioso entre as partes interessadas.

A Confederação Nacional da Indústria - CNI -, por sua vez, considera que um dos grandes desafios do mundo atual é conciliar crescimento econômico e social com equilíbrio ecológico.

Para que tal desafio seja adequadamente superado, a CNI considera essencial que as indústrias, fundamentadas no conceito de desenvolvimento sustentável, desenvolvam suas atividades compromissadas com a proteção do meio ambiente, a saúde, a segurança e o bem estar dos seus 
trabalhadores e das comunidades.

Neste sentido, a CNI editou uma Declaração de Princípios da Indústria para o Desenvolvimento Sustentável propondo a participação próativa do setor industrial, em conjunto com a sociedade e o Estado, no sentido de desenvolver e aperfeiçoar leis, regulamentos e padrões ambientais.

Tal Declaração propõe ainda o uso racional dos recursos naturais e de energia e o aperfeiçoamento dos sistemas de gerenciamento ambiental, saúde e segurança do trabalho nas empresas.

Neste último item, a CNI reconhece a importância do envolvimento contínuo e permanente dos trabalhadores e do comprometimento da supervisão nas empresas, e apóia a educação e o treinamento necessários com relação às questões ambientais.

A CNI também criou em 1997 o Prêmio CNI de Ecologia com os objetivos gerais de estimular o uso adequado dos recursos naturais e das modernas técnicas de gestão ambiental e difundir informações relativas às práticas e técnicas bem sucedidas na gestão ambiental.

Podem concorrer ao Prêmio quaisquer indústrias que tenham desenvolvido iniciativas para a melhoria da qualidade do meio ambiente.

Finalmente, citamos o Conselho Empresarial Brasileiro para o Desenvolvimento Sustentável - CEBDS - criado em 1997 como parte da rede de conselhos vinculada ao World Business Council for Sustainable Development. É uma entidade nacional formada por empresários e já contava com a adesão de mais de 50 empresas.

Este Conselho assume que desenvolvimento sustentável é um conceito que busca conciliar as necessidades econômicas, sociais e ambientais sem comprometer o futuro de quaisquer destas demandas.

Sua posição pretende que os setores produtivos contribuam para 0 crescimento econômico através de ações direcionadas também para questões sociais e ambientais.

Vimos que as entidades que agrupam empresas se referem a sistemas de gerenciamento ou gestão ambiental. Estes sistemas caracterizam o recorte do nosso estudo e assim passamos a indicar suas origens e funcionamento. 


\subsection{Sistemas de gestão ambiental e norma ISO 14001}

Voltando para o nível internacional, em muitos países encontramos entidades há muito estabelecidas que lidam com a normatização técnica de processos e produtos industriais e de serviços.

Estas entidades representam a ISO - International Organization for Standardization -, uma federação mundial de entidades de normatização que promove normas internacionais de aceitação voluntária.

No Brasil a ISO é representada pela ABNT - Associação Brasileira de Normas Técnicas, entidade privada, que traduz e publica normas técnicas.

Quando, na década de 1980, estava bem reconhecida a participação de todos os trabalhadores de uma empresa na obtenção de produtos e serviços de qualidade, surgiram os princípios básicos para a gestão de qualidade total.

Gestão de qualidade total focaliza a satisfação do cliente, o aperfeiçoamento contínuo da organização e de todos os funcionários na resolução dos problemas da qualidade, o respeito ao indivíduo e aos seus conhecimentos e habilidades, o trabalho em equipe e, principalmente, a confiança.

Para estes princípios a ISO editou uma série de normas de qualidade (série 9000) por acreditar que produtos e serviços nivelados concorrem melhor no mercado globalizado.

Apesar do nivelamento pretendido, ter seu sistema de qualidade certificado como de acordo com as normas ISO 9000 passou a ser uma vantagem competitiva para as empresas porque estabelece a imagem de boa qualidade em produtos e serviços.

As normas ISO 9000 resultaram do esforço de dezenas de especialistas de todo o mundo e foram rapidamente aceitas. Definem procedimentos e critérios para garantir que os bens e serviços produzidos atendam às necessidades dos clientes e orientam a implementação, a documentação e a manutenção de um Sistema da Qualidade que se pretende eficaz e econômico.

Mas são normas de administração e não de especificação do produto. 
Em 1992 entraram em vigor as normas britânicas BS7750 Specification for Environmental Management Systems - que serviram de base para a elaboração de normas internacionais para sistemas de gestão ambiental denominadas de série ISO 14000.

A gestão ambiental visa qualidade ambiental ou o equilíbrio entre as atividades da empresa e o ecossistema onde tais atividades se inserem. $E$ qualidade ambiental envolve o ciclo de vida de um produto, o tratamento de efluentes e de qualquer fator que afete a vizinhança das instalações produtivas.

Valle (1995: 16) esclarece que "as ferramentas utilizadas para alcançar a Qualidade Ambiental são, em sua essência, idênticas àquelas utilizadas pela empresa para assegurar sua qualidade de produção: treinamento, plano de ação, controle da documentação, organização e limpeza, inspeções e análises periódicas da situação".

Assim houve a elaboração da série ISO 14000 composta por normas ambientais que auxiliam as indústrias a integrar aos seus negócios os princípios de desenvolvimento sustentável e gestão ambiental.

A série ISO 14000 pode ser dividida em dois grupos de normas:

- um direcionado para a organização - Sistemas de gestão ambiental, Avaliação de desempenho ambiental e Auditoria ambiental;

- outro direcionado para o produto - Rotulagem ambiental, Análise do ciclo de vida do produto e Aspectos ambientais nas normas de produtos.

A ISO forma comitês técnicos para elaboração de suas normas, constituídos por associações normativas de vários países garantindo, se não um extenso diálogo, extensos pactos.

A ABNT participa do comitê para gestão ambiental através do Grupo de Apoio à Normatização Ambiental - GANA - que deve tomar a forma de um Comitê Brasileiro de Meio Ambiente, com membros empresariais e pesquisadores.

Editada primeiramente em 1996, com revisões periódicas previstas, a série ISO 14000 inclui as normas:

14001 - de especificações para sistemas de gestão ambiental

14004 - de princípios para sistemas de gestão ambiental

14010 - de princípios gerais para auditoria ambiental 
14011 - de procedimentos para auditorias de sistemas de gestão ambiental 14012 - de qualificação de auditores ambientais

A norma ISO 14001, única certificável, apenas orienta a implantação de sistemas de gestão ambiental, não sendo legislativa (Reis, 1995).

Mas está tendo a mesma rápida aceitação que as normas de qualidade total da série ISO 9000 por requerimento de clientes, como estratégia de mercado e como fator motivacional.

Em 1997, foram emitidos 4433 certificados ISO 14001 em 55 países. Em 1998 este numero passou para 7887 certificados em 72 países, estando 6786 destas empresas situadas na Europa e Extremo Oriente.

Até fins de 2000, 22.897 empresas no mundo, distribuídas em 98 países, estavam com sistemas de gestão ambiental certificados pela norma ISO 14001.

No Brasil, em 2000, 191 empresas estavam com seus sistemas de gestão ambiental certificados de acordo com a norma ISO 14001.

A certificação, para ter credibilidade, requer cuidados. São assim importantes as normas sobre as auditorias ambientais e o envolvimento de instituições públicas e privadas com reconhecimento internacional.

Para atestar qualidade de produtos, processos, sistemas ou serviços, no Brasil está organizado o Sistema Brasileiro de Certificação instituído pelo Conselho Nacional de Metrologia, Normalização e Qualidade Industrial CONMETRO.

O Sistema Brasileiro de Certificação possui como organismos: o Comitê Brasileiro de Certificação, os Organismos de Certificação Credenciados e o Instituto Nacional de Metrologia, Normalização e Qualidade Industrial - INMETRO - que é seu organismo de credenciamento.

Os organismos credenciados pelo INMETRO são os realizam então as atividades de certificação de conformidade e treinamento de pessoal. São empresas privadas, de economia mista ou fundações prestadoras de serviços de certificação.

O credenciamento do INMETRO permite que os organismos de certificação concedam certificados com validade oficial. Este credenciamento é aberto às entidades interessadas e regido por contrato entre a entidade e o INMETRO, com validade determinada. 
Exige a realização de auditorias e pode ser mantido, suspenso ou cancelado.

Os especialistas dos organismos de certificação, por exemplo os que atuam em auditorias de sistemas de gestão ambiental, seguem normas do INMETRO que estabelecem os requisitos para cada qualificação.

A certificação de conformidade é um modelo de acreditação, ou seja, um documento emitido pela entidade de certificação que atesta a conformidade e qualidade de produtos e processos (qualquer material, equipamento, procedimento, método e atividade de pessoas) com base em normas elaboradas por entidades reconhecidas ou com base em regulamentos técnicos emitidos por órgãos oficiais.

A certificação de uma empresa, ou melhor, de seus sistemas, pode ser compulsória, quando envolve questões de segurança, proteção da saúde e do meio ambiente, ou pode ser voluntária.

O processo de certificação de sistema de gestão ambiental segundo a norma ISO 14001 ocorre pelo fluxograma genérico descrito abaixo:

a. Empresa $\Rightarrow$ implanta o sistema $\Rightarrow$ solicita proposta para certificação $\Rightarrow$ responde questionário preliminar da Certificadora

b. Certificadora $\Rightarrow$ analisa documentos $\Rightarrow$ faz pré-auditoria da Empresa

c. Empresa $\Rightarrow$ corrige não-conformidades

d. Certificadora $\Rightarrow$ faz auditoria de certificação $\Rightarrow$ faz reauditoria se necessário, após correção de não-conformidades $\Rightarrow$ emite certificado e contrato para auditorias de acompanhamento

Para auditoria inicial o organismo de certificação solicita da empresa interessada uma descrição da(s) unidade(s) incluída(s) no sistema de gestão ambiental, com localização, área ocupada, número de funcionários, turnos de trabalho, descrição dos setores e atividades de cada setor, seus principais impactos ambientais e mitigadores (como processos de tratamento de água e efluentes, disposição de resíduos, etc.). 
$\mathrm{Na}$ empresas, o sistema de gestão ambiental deve contemplar os seguintes elementos:

1. política ambiental - diretriz documentada e pública declarando as intenções da empresa na área do desempenho ambiental

2. planejamento

2.1. levantamento dos aspectos ambientais da empresa

2.2. identificação dos requisitos legais e de outros (como da atuação responsável) e dos procedimentos atuais

2.3. arrolamento de objetivos e metas quantificáveis

2.4. definição do programa de gestão ambiental - ações para que se atinjam os objetivos e metas propostos

3. implantação

3.1. definição de responsabilidades, recursos e prazos

3.2. treinamento

3.3. comunicação

3.4. documentação - manual ou similar

3.5. controle de documentos - necessário para a criação de planos, procedimentos e instruções de trabalho e para disponibilizá-los

3.6. controle operacional - através de procedimentos documentados

- dos processos geradores dos aspectos ambientais

- dos processos de tratamento de poluentes

- dos processos de manuseio, transporte e armazenamento

- de atividades e produtos fornecidos por terceiros

3.7. preparação e atendimento a emergências

4. verificação e ação corretiva

4.1. monitoramento - coleta e análise de dados, calibração e manutenção de instrumentos

4.2. ações preventivas e corretivas

4.3. registros

4.4. auditoria

5. análise crítica pela administração 
Apesar da complexidade e custos, Fredericks e McCallum (1995) apontam como benefícios de um Sistema de Gestão Ambiental:

- maior adequação à legislação;

- facilitação de transações financeiras e comerciais, quando a performance ambiental é um fator a ser considerado;

- redução de custos de auditoria de consumidores;

- aumento na habilidade de negociar;

- ganho de força no mercado;

- retorno econômico por aumento de eficiência no uso de recursos;

- aumento da habilidade de adaptação a mudanças.

Mas a ISO 14001 já recebe críticas, mesmo com seu pouco tempo de aplicação. As principais críticas são que esta norma privilegia o modelo curativo de end-of-pipe e a conformidade nos limites da lei ambiental vigente onde a empresa está instalada.

Espera-se que as normas de Rotulagem Ambiental, de Avaliação do Desempenho Ambiental e de Avaliação do Ciclo de Vida do Produto contribuam para iniciativas mais pró-ativas das empresas.

Furtado et al. (2000) criticam os sistemas de gestão ambiental que se apoiam na norma ISO 14001 como sendo somente sistemas administrativos, sem maiores compromissos com as questões ambientais.

Estes autores defendem o emprego de princípios de Produção Limpa, ou de Produção Mais Limpa, além da requalificação dos funcionários, e colocam a geração de resíduos como problema central dos impactos ambientais.

Os princípios da Produção Limpa surgiram nos anos 80 como proposta da organização não-governamental Greenpeace, e ganharam maior visibilidade na década de 90 com o Programa Produção Mais Limpa do PNUMA - Programa das Nações Unidas para o Meio Ambiente.

Produção Limpa e Produção Mais Limpa defendem a prevenção de resíduos na fonte, a exploração sustentável de fontes de matérias-primas, a economia de água e energia e o uso de outros indicadores ambientais para a indústria. 
Produção Limpa é mais restritiva pois estabelece compromissos para precaução em caso de qualquer dúvida ou suspeita de dano ambiental, real avaliação do ciclo de vida dos produtos, e direito de acesso público a informações sobre riscos ambientais de processos e produtos para um controle democrático dos procedimentos.

O objetivo da Produção Limpa é usar com eficiência materiais e energia renováveis e não-nocivos, conservando ao mesmo tempo a biodiversidade. Os sistemas de Produção Limpa são circulares e usam menor número de materiais, menos água e energia. Os recursos fluem pelo ciclo de produção e consumo em ritmo mais lento.

Em primeiro lugar, os princípios da Produção Limpa questionam a necessidade real do produto ou procuram outras formas pelas quais essa necessidade poderia ser satisfeita ou reduzida.

A Produção Limpa também implementa o Princípio Precautório uma abordagem holística e integrada para questões ambientais, centrada no produto. Essa abordagem assume como pressuposto que a maioria de nossos problemas ambientais - por exemplo aquecimento global, poluição tóxica, perda de biodiversidade - é causada pela forma e ritmo no qual produzimos e consumimos recursos.

O Enfoque Precautório prevê que o ônus da prova fique a cargo do agente poluidor em potencial, para que ele demonstre que uma substância ou atividade não causará danos ambientais, em vez de ser responsabilidade das comunidades provar esse dano.

Essa abordagem rejeita o uso exclusivo da avaliação quantitativa do risco na tomada de decisões, pois reconhece as limitações do conhecimento científico para determinar se o uso de uma substância química ou atividade industrial é procedente. Ela não ignora a ciência, mas reconhece que, como a produção industrial tem também impacto social, outros profissionais com poder para tomar decisões, além dos cientistas, devem estar envolvidos.

Produção Limpa tem também Enfoque Preventivo, pois é mais barato e eficiente prevenir danos ambientais do que controlá-los ou remediá-los.

A prevenção da poluição substitui seu controle e assim requer que se parta do início do processo de produção para evitar a fonte do problema, em vez de tentar controlar os danos em seu final. 
Por exemplo, a prevenção requer alterações de processos e produtos para impedir a geração de resíduos incineráveis, em vez de se desenvolver incineradores sofisticados.

Analogamente, práticas de uso eficiente de energia, na demanda e na oferta, substituem a atual ênfase exagerada no desenvolvimento de novas fontes de energia.

Para melhor exemplificar a Produção Limpa, apresentamos os indicadores para empresas ambientalmente adequadas utilizados pelo Grupo de Produção Limpa da Fundação Vanzolini e Departamento de Engenharia de Produção da Escola Politécnica da Universidade de São Paulo (no ano de 2000):

\section{Fontes de recursos - extração}

- garante a viabilidade do ecossistema

- há reposição de estoques naturais

- há eficiência e eficácia no consumo de água e energia

Matérias-primas ou eco-materiais

- são naturais e renováveis

- são simples ou, se mistos, são separáveis e recicláveis

- o reprocessamento é atóxico, água e energia-eficiente

- são leves e utilizados em pequenos volumes

Processo de produção

- é atóxico, água e energia-efetivo

- há fechamento de ciclos e reuso de materiais

\section{Produto}

- é atóxico

- tem maior vida útil que o similar

- é fácil de desmontar, remontar e consertar

- é remanufaturável

- é elaborado com resíduo ou material reciclado

- funciona com baixo consumo de energia e de água

- usa o mínimo de embalagem

- a embalagem é reciclável

Tecnologia limpa

- resíduo zero ou mínimo

- entradas e saídas mínimas de materiais tóxicos

- utiliza energia limpa

- reciclagem atóxica, água e energia eficientes

- adota o princípio da precaução e da prevenção

Marketing ambiental

- pratica o uso compartilhado de produtos, processos e serviços

- o produto é gerador de mercado de segunda mão

- tem responsabilidade estendida

- pratica o direito de acesso público à informação

Manejo ambiental

- pratica a prevenção de resíduos na fonte de produção

- faz reciclagem primária (on site) e secundária (off site)

- não faz despejo em aterros

- não usa a incineração

- adota padrões elevados de saúde e segurança no trabalho 


\section{Conformidade ambiental}

- atende a legislação nacional e local

- não importa lixo tóxico

- não utiliza poluentes orgânicos persistentes

- não provoca poluição transfronteiriça

- não contribui para o aquecimento do planeta

- não provoca destruição da camada de ozônio

- não causa poluição marinha e de estuários

- não comercializa espécies em extinção

- não prejudica a biodiversidade

Comunicação ambiental

- divulga sua política e práticas ambientais

- publica Relatório Ambiental

Ricardo Hojda (1998) afirma que é consenso que a certificação ISO 14001 não garante que uma instalação tenha alcançado o melhor desempenho ambiental possível.

Isto porque a norma tem em vista o processo produtivo, seus impactos ambientais diretos ou indiretos, mas não está voltada para o desempenho ambiental do produto, nem inclui requisitos de gestão da segurança e saúde.

Porém a certificação garante que a empresa realiza atividades de gestão ambiental que tem como base o controle dos processos. Controle este sistematizado através da aplicação do ciclo denominado PDCA (do inglês plan, do, check, action), ou seja, planejar, implantar, avaliar e rever ou atuar corretivamente.

A certificação de um sistema de gestão ambiental pelas normas ISO 14001 permite a determinação de efeitos ou impactos ambientais, a avaliação de riscos ambientais, a preparação de planos de emergência, a realização de relatórios de auditoria ambiental, e a implementação de medidas recuperadoras e protetoras do meio ambiente.

Conduz, em princípio, à gestão de resíduos, diminuição da poluição e uso racional de energia mas pode significar mais estimulando a busca de soluções e a pesquisa e desenvolvimento de novos produtos.

Com este capítulo tivemos como objetivo indicar especificidades de empresas em relação às questões ambientais para auxiliar no entendimento da lógica empresarial, ou seja, do modelo empresarial de meio ambiente, que faz parte dos nossos objetos de estudo.

Passamos, a seguir, a apresentar o estudo de caso como proposto na Introdução. 


\section{DIFUSÃO DE CONHECIMENTOS AMBIENTAIS NA INDÚSTRIA: FÁBRICA UNILEVER EM VINHEDO, SP}

Como explicamos na Introdução, optamos por um universo único, pautados em uma realidade física única, mas tendo em foco as relações de difusão de conhecimentos sobre o meio ambiente que se estabelecem em uma estrutura constituída pelas partes 'espaço-empresa-trabalhadores'.

Apresentamos assim três subcapítulos, referentes a esta estrutura, discutindo em cada um deles os modelos mentais de meio ambiente que denominamos modelo acadêmico, modelo empresarial e modelo do senso comum.

\subsection{O município de Vinhedo}

O município de Vinhedo, no Estado de São Paulo, está inserido na Região Metropolitana de Campinas (Figura 1), que veio se desenhando na década de 90 . Ocupa área de $82 \mathrm{~km}^{2}$ e a sede localiza-se no ponto com Latitude -23,02972 e Longitude -46,97528, distando $76 \mathrm{~km}$ da cidade de São Paulo e $18 \mathrm{~km}$ de Campinas, pelas rodovias Anhanguera e Bandeirantes.

O relevo da região é de planalto e a área deste município tem topografia de conformação suave, com altitude de $700 \mathrm{~m}$ acima do nível do mar. O clima classifica-se como temperado, úmido e quente com inverno seco: a pluviosidade é de $1404 \mathrm{~mm}$ anual sendo janeiro o mês mais chuvoso e julho o mês mais seco; a temperatura máxima média é de $28^{\circ} \mathrm{C}$ e a mínima média é de $19^{\circ} \mathrm{C}$. 


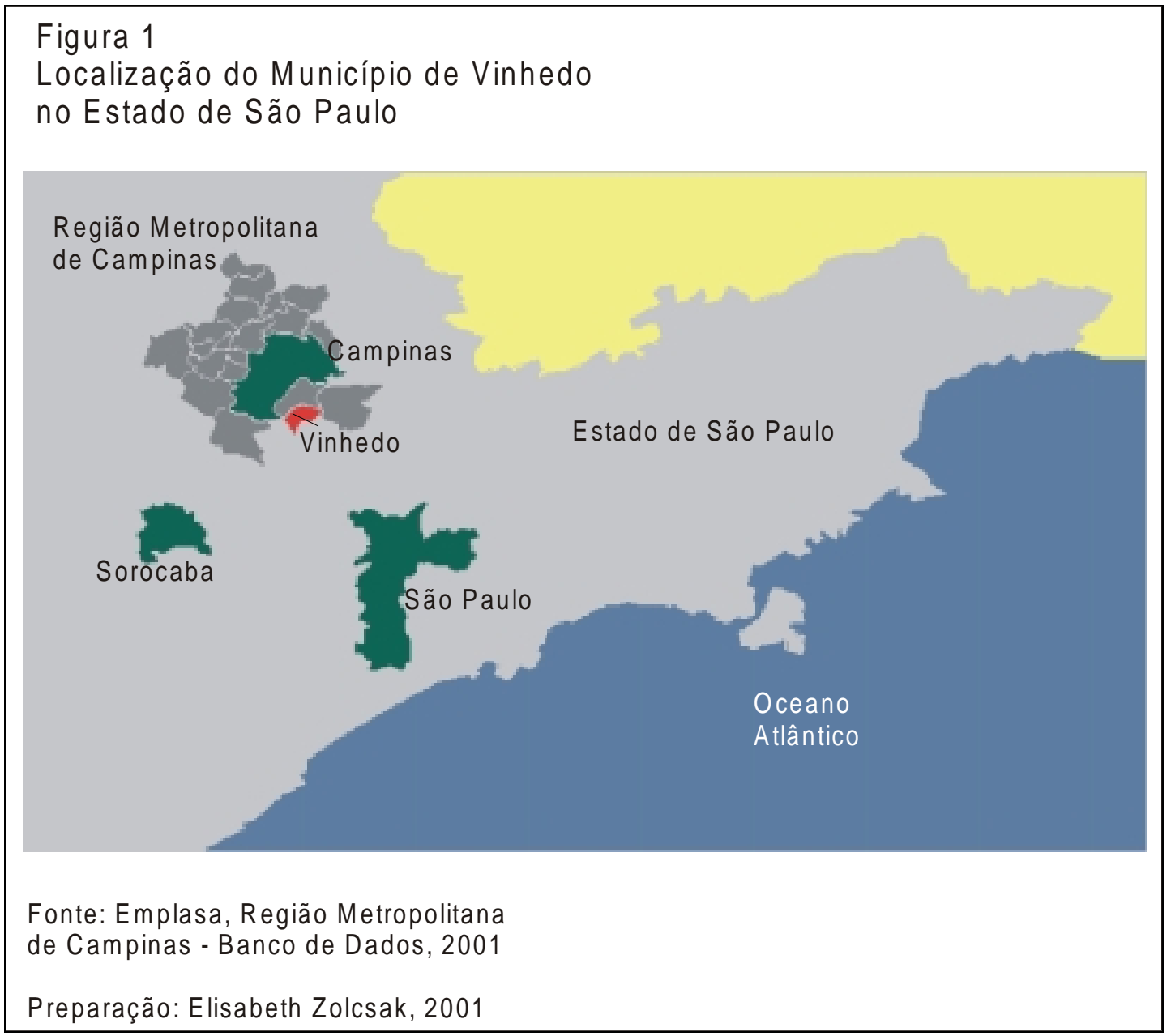

\subsubsection{Aspectos históricos do município de Vinhedo}

Vinhedo, que completou 50 anos de emancipação políticoadministrativa no dia dois de abril de 1999, surgiu como assentamento na época do ciclo do ouro, por volta de 1615 e 1620, quando os exploradores fizeram surgir algumas vilas, simples locais de passagem e pouso, nos caminhos de São Paulo para o interior. Posteriormente o local fez parte de uma grande fazenda de café denominada Cachoeira. Pela proximidade a Jundiaí, a vila passou a receber novos moradores estabelecendo-se como vila de Rocinha em 1840.

Em meados do século XIX, formou-se na região o mais significativo quilombo da Província de São Paulo: o "Quilombo da Rocinha", que por ser perseguido constantemente deslocou-se por diversas fazendas da região. 
Em 1908, o então presidente da Província de São Paulo, Albuquerque Lins, promulgou a Lei que "Cria o Distrito de Paz de Rocinha, no município de Jundiahy".

Cortado pela Companhia Paulista de Estradas de Ferro, o Distrito foi assumindo condições urbanas de um povoado em desenvolvimento com arruamentos e benfeitorias.

Além das grandes fazendas de café, a agricultura do Distrito de Rocinha passou a caracterizar-se pela grande quantidade de videiras que fizeram surgir indústrias vinícolas caseiras e a indicação do nome Vinhedo quando se iniciou o movimento para emancipação político-administrativa da vila.

A emancipação ocorreu em 1948, com posse de prefeito e vereadores em 1949. O novo município paulista englobava a atual Louveira, emancipada em 1965.

Já na década de 20 foi construída a primeira indústria do Distrito: a Fiação e Tecelagem Sant'Anna, que posteriormente mudou o nome para B. Storani S/A - Comercial, Industrial, Agrícola e Pastoril. Em 1947 foi fundada a Cerâmica Jatobá, e em 1953 a Carborundum até hoje na cidade.

Atualmente a indústria é responsável por $80 \%$ da economia do município, com mais de 190 empresas instaladas, acompanhando a nova base produtiva no eixo Jundiaí/Piracicaba que ocorreu com a desconcentração industrial da Região Metropolitana de São Paulo.

A cidade procura também ter opções turísticas, e atraiu grande investimento com o Parque Temático Hopi Hari, no percurso da Rodovia Bandeirantes que passa pelos limites de Vinhedo e Itupeva.

\subsubsection{Descrição do município de Vinhedo}

Vinhedo é o 9o município mais rico do Estado de São Paulo (dados da Prefeitura Municipal divulgados em 2001), riqueza calculada pelo consumo de energia, salário médio do emprego formal, valor adicionado per capita. Este valor adicionado se refere às despesas per capita em saúde, saneamento básico e educação, feitas pelo poder público. 
São índices destes investimentos na área social a longevidade em diversas faixas etárias, a taxa de mortalidade perinatal e a escolaridade da população, consideradas perante a arrecadação municipal.

A arrecadação de Vinhedo se distribui entre receitas próprias (IPTU Imposto Predial e Territorial Urbano, ISS - Imposto sobre Serviços e ITBI Imposto sobre a Transmissão de Bens Imóveis), na base de 40\%, e repasses estaduais da arrecadação de ICMS - Imposto sobre a Circulação de Mercadorias e Serviços e IPVA - Imposto sobre a Propriedade de Veículos Automotores, perfazendo cerca de $60 \%$ da arrecadação total.

O orçamento para 2001 foi de $R \$ 63$ milhões colocando Vinhedo no $33^{\circ}$ posto per capita da arrecadação de ICMS no Estado de São Paulo e no $20^{\circ}$ posto per capita da arrecadação de impostos próprios.

O número total de habitantes, registrado no censo do ano 2000 do IBGE, é de 47215 sendo:

\begin{tabular}{l|l} 
habitantes na área urbana & habitantes na área rural \\
\hline 46174 & 1041
\end{tabular}

A taxa de urbanização é, portanto, de $97,79 \%$ e a densidade demográfica é de 575,79 habitantes $/ \mathrm{km}^{2}$. Há 15644 domicílios registrados no censo e a taxa de crescimento da população, entre 1996 e 2000, foi de $22,52 \%$

Em 1996 a projeção de população, já ultrapassada, era dada pelo SEADE (Fundação Sistema Estadual de Análise de Dados) como:

\begin{tabular}{l|l|l|l} 
ano & 2000 & 2005 & 2010 \\
\hline habitantes & 42825 & 48521 & 54283
\end{tabular}

A tabela a seguir (Tabela 2) auxilia a análise das características demográficas de Vinhedo e região, com taxas de crescimento elevadas em relação às taxas do Estado e do País. 
Tabela 2 - Características demográficas de Vinhedo -1980 -1996

População total (habitantes), taxa de crescimento anual - tc a.a. (\%) e taxa de urbanização - tu (\%)

\begin{tabular}{l|l|l|l|l|l|l|l} 
& 1980 & 1991 & $\begin{array}{l}\text { tc } \\
\text { a.a. }\end{array}$ & tu & 1996 & $\begin{array}{l}\text { tc } \\
\text { a.a. }\end{array}$ & \\
\hline Vinhedo & 21.494 & 33.355 & 4,07 & 98,18 & 38.534 & 2,87 & 98,30 \\
\hline $\begin{array}{l}\text { total da } \\
\text { UGRHI PCJ * }\end{array}$ & 2.493 .489 & 3.496 .607 & 3,12 & 92,32 & 3.890 .892 & 2,15 & 93,24 \\
\hline total SP & 24.953 .238 & 31.509 .643 & 2,12 & 92,8 & 34.074 .644 & 1,58 & 93,11 \\
\hline total BRASIL & 119.002 .706 & 149.825 .475 & 1,26 & 75,59 & 157.079 .573 & 1,40 & 78,40
\end{tabular}

Fonte: SEADE

* UGRHI-PCJ = Unidade de Gerenciamento de Recursos Hídricos das bacias dos rios Piracicaba, Capivari e Jundiaí - Municípios integrantes:

Águas de São Pedro, Americana, Amparo, Analândia, Artur Nogueira, Atibaia, Bom Jesus dos Perdões, Bragança Paulista, Campinas, Charqueada, Cordeirópolis, Corumbataí, Cosmópolis, Holambra, Hortolândia, Ipeúna, Iracemápolis, Itatiba, Jaguariúna, Jarinu, Joanópolis, Limeira, Monte Alegre do Sul, Morungaba, Nazaré Paulista, Nova Odessa, Paulínia, Pedra Bela, Pedreira, Pinhalzinho, Piracaia, Piracicaba, Rio Claro, Rio das Pedras, Saltinho, Santa Bárbara d'Oeste, Santa Gertrudes, Santa Maria da Serra, Santo Antônio de Posse, São Pedro, Sumaré, Tuiuti, Valinhos, Vargem, Vinhedo, Capivari, Elias Fausto, Louveira, Mombuca, Monte Mor, Rafard, Campo Limpo Paulista, Indaiatuba, Itupeva, Jundiaí, Salto, Várzea Paulista.

O sistema público de saúde conta com um hospital, pronto-socorro e 8 postos de saúde localizados em diferentes bairros. E o sistema escolar está provido com 6 pré-escolas, 15 escolas de ensino fundamental, 5 escolas de ensino médio e 1 estabelecimento de ensino superior (dados da Prefeitura Municipal de Vinhedo).

O número de habitantes com 10 anos ou mais de idade é de 40058 e a taxa de alfabetização da população é de $94,6 \%$.

Quanto ao emprego formal, dados do SEADE para 1999 indicavam em Vinhedo 13091 vagas ocupadas sendo:

2134 empregos em 410 estabelecimentos do comércio

6339 empregos em 199 estabelecimentos da indústria 4618 empregos em 314 estabelecimentos de serviços

Porém muitos destes empregos são ocupados por trabalhadores nãoresidentes no município de Vinhedo, vindo de municípios próximos. 
Descrevendo o município em seu desenho geral, encontramos que, ao lado de moradias mais simples e de padrão médio, $10 \%$ da população mora em condomínios de alto padrão, com terreno mínimo de $800 \mathrm{~m}^{2}$. A Prefeitura não registra favelas, cortiços ou habitações em área de risco no município, mas apontou para 5 loteamentos irregulares em 1998.

Como áreas livres destacam-se:

- a Represa João Gasparini, ou Represa II - principal ponto turístico da cidade, dista 1,5 quilômetro do Centro e conta com fonte natural, praças, quadras esportivas e locais para realização de eventos;

- o Bosque Municipal José Carlos Guinco - localizado fora do perímetro urbano da cidade, trata-se de uma reserva florestal utilizada para lazer;

- Praça do Aquário - no Centro da cidade, com lago e equipamentos diversos, esta praça é muito utilizada pelos moradores para lazer.

A Figura 2 (página seguinte) auxilia na descrição do município em seu desenho geral indicando categorias de uso e ocupação do solo, área urbana e sistema rodoviário, área industrializada e área com cobertura vegetal em preservação. 


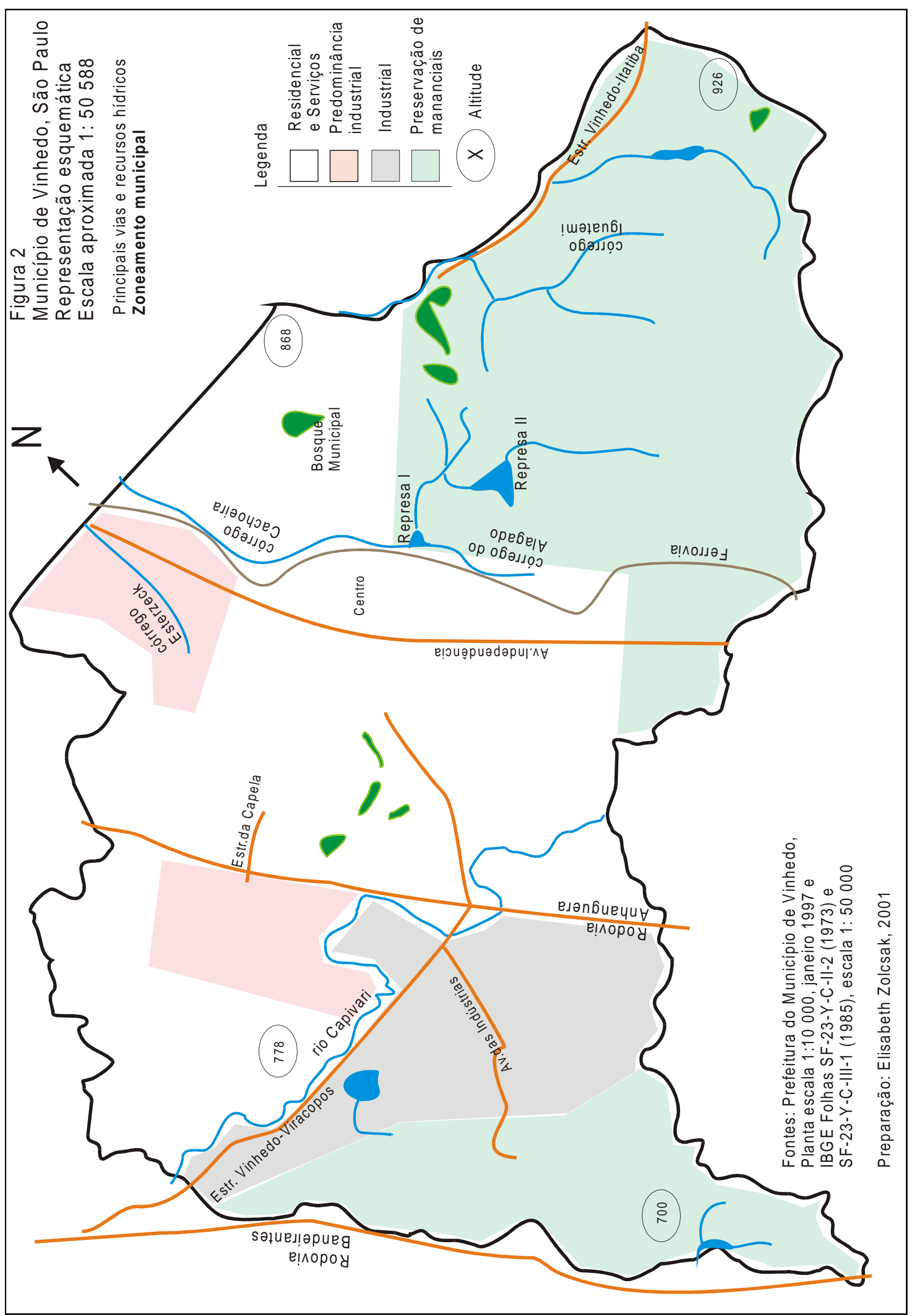


Vinhedo não possui Unidades de Conservação mas apresenta áreas com vegetação nativa remanescente (em processo de cadastramento), áreas com possibilidade de serem protegidas como corredores de fauna e áreas de preservação permanente ao longo dos cursos d'água. De acordo com o IBGE, o município apresentava, em 1991, 9,1\% de sua área com cobertura vegetal natural.

A cobertura vegetal natural da região se classifica como mata, cerrado (tipo de vegetação formado pela estação seca prolongada, ao lado das condições edáficas), capoeira (vegetação secundária em diversos estágios sucessionais de regeneração) e cobertura vegetal natural de várzea (vegetação arbórea e arbustiva sujeita a inundações periódicas associadas aos terraços e planícies aluviais).

As matas da região se tipificam como floresta umbrófila densa (com árvores que variam de médio a grande porte com presença de trepadeiras, palmeiras e epífitas em abundância) e floresta estacional semidecidual condicionada a uma estação climática tropical de intensas chuvas de verão seguida por estiagem e outra subtropical com seca fisiológica provocada pelo frio do inverno.

Ainda quanto à vegetação, encontramos que o Levantamento Censitário de Unidades de Produção Agrícola do Estado de São Paulo, em 1995/96, trazia para Vinhedo:

- 346,60 ha com culturas perenes;

- 6,00 ha com culturas semi-perenes;

- 913,30 ha com culturas anuais;

- 2.081,40 ha com pastagem (braquiária);

- 800,50 ha de reflorestamento. 
Como recursos hídricos de Vinhedo, são importantes o córrego Cachoeira e o rio Capivari (com situação geográfica indicada na Figura 3) que fornecem a água para o abastecimento público do município. Os lançamentos de águas servidas se dão no córrego dos Pinheiros e afluentes e no rio Capivari.

Aproximadamente $90 \%$ da população é atendida com saneamento básico (água ou água e esgoto).

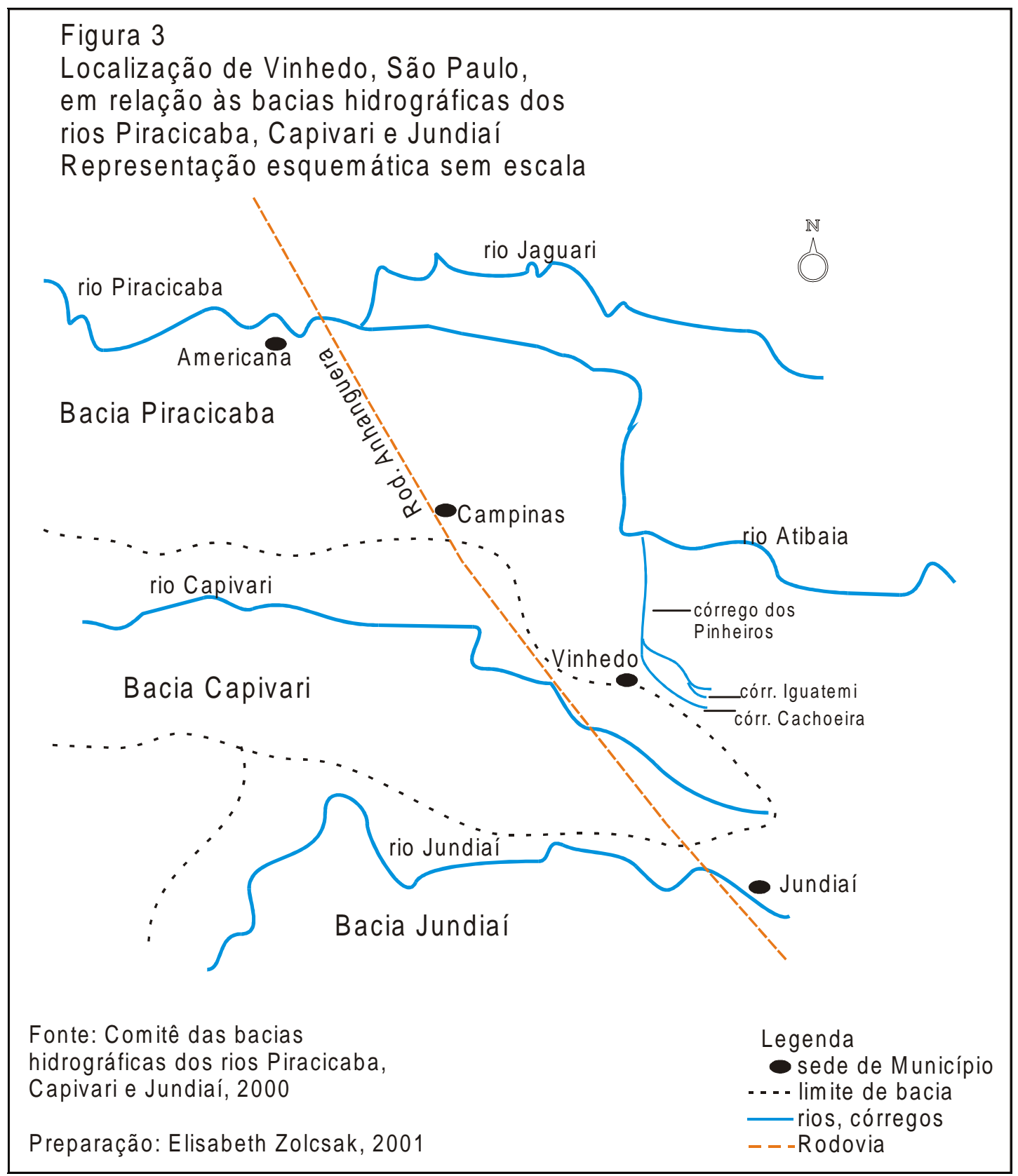


Quanto aos aspectos jurídico-institucionais relativos às questões de política urbana, Vinhedo possui Lei Orgânica, Plano Diretor, Código de Obras, Atos legais de uso e ocupação do solo, incluindo parcelamento do solo e perímetro urbano e Cadastros de redes de água, esgotos e energia elétrica. Não possui Atos legais de proteção ou controle ambiental e apenas o Plano Diretor trata do meio ambiente quando disciplina a ocupação das áreas do município.

Para planejamento territorial de Vinhedo, o Decreto o 31 de 30/3/2001 suspende por tempo indeterminado a aprovação de projetos de loteamentos, regidos pela Lei do Plano Diretor Físico e Territorial do Município - Lei Municipal no 1.210/84, pela necessidade de revisão deste Plano justificada pela ausência atual de infra-estrutura apropriada, em saúde, educação e saneamento. $O$ Decreto não suspende os empreendimentos com processo já em andamento e os com diretrizes de viabilidade já expedidas, além daqueles com interesse social (item que, na prática, pode permitir loteamentos destinados à habitação em padrões mais simples).

O Decreto citado indica que a Administração Pública reconhece a atual saturação demográfica de Vinhedo em relação à infra-estrutura ou aos serviços públicos urbanos oferecidos mas procuramos outras fontes para explicitar os problemas ambientais do município.

Como esboço das questões ambientais do local, anotamos o editorial de 28 de abril de 2001 do Jornal de Vinhedo. O texto protesta contra os dois grandes condomínios da cidade - Marambaia e São Joaquim - cujos moradores não aprovaram em assembléia a construção de rede de esgoto, diferenciando-se dos que pagam e tornando-se contribuintes da poluição dos recursos hídricos.

O editorial aborda exatamente a escassez de água em Vinhedo e descuidos com a água disponível. Cita o transbordamento das represas e a falta de preservação das nascentes em todo o município; assim, por assoreamento, os pequenos córregos existentes nas proximidades das represas não colaboram com o abastecimento. 
Por fim, o editorial citado questiona a perfuração de poços que pode prejudicar o aqüífero da região e onerar a população pelo pagamento da empresa exploradora sem que esta ofereça a vazão necessária. E, por fim, defende o uso principal da água superficial reiterando queixas pelo descaso com as nascentes próximas às represas.

\subsubsection{Problemas ambientais em Vinhedo}

Os problemas ambientais de Vinhedo despontam nos levantamentos do Comitê das Bacias Hidrográficas dos rios Piracicaba, Capivari e Jundiaí, no principal jornal do município (Jornal de Vinhedo) e nas ações e planos da sua Secretaria de Planejamento e Meio Ambiente.

Referem-se à degradação e esgotamento de recursos hídricos, disposição de resíduos sólidos, degradação de áreas verdes e excesso de loteamentos com aumento da demanda de serviços públicos e movimento de terra.

\subsubsection{Recursos hídricos}

Para gerenciamento de recursos hídricos o Estado de São Paulo está hoje dividido em 22 Unidades. Este sistema de unidades foi iniciado em 1987 com o Decreto Estadual № 27.576 que criou o primeiro Conselho Estadual de Recursos Hídricos - $\mathrm{CRH}$, composto exclusivamente por órgãos e entidades do Governo do Estado, com a incumbência de propor a política relativa aos recursos hídricos do Estado, estruturar um Sistema Integrado de Gerenciamento dos Recursos Hídricos - SIGRH e elaborar o Plano Estadual de Recursos Hídricos - PERH.

A Constituição Estadual de 1989 instituiu, por lei, o Sistema Integrado de Gerenciamento dos Recursos Hídricos - SIGRH congregando órgãos estaduais, municipais e a sociedade civil e assegurando a gestão descentralizada, participativa e integrada em relação aos demais recursos naturais e às peculiaridades das bacias hidrográficas. 
A Lei № 7.663 de 1991, regulamentando a Constituição Estadual, estabeleceu as diretrizes para atualização periódica do Plano Estadual de Recursos Hídricos, os instrumentos da Política Estadual de Recursos Hídricos e os seus princípios.

Tais princípios são: o gerenciamento integrado, descentralizado e participativo; a adoção da bacia hidrográfica como unidade físico-territorial de planejamento; o reconhecimento do recurso hídrico como um bem público de valor econômico, cuja utilização deve ser cobrada; a compatibilização do gerenciamento dos recursos hídricos com o desenvolvimento regional e com a proteção do meio ambiente.

Entre os meios para assegurar a participação da sociedade estão a participação paritária do Estado, Municípios e Sociedade Civil no Conselho Estadual de Recursos Hídricos - CRH e nos Comitês de Bacia Hidrográfica.

O CRH foi instalado em 1993 e é composto por 11 representantes de Secretarias de Estado, 11 representantes dos Municípios e 11 representantes de entidades da sociedade civil relacionadas diretamente aos recursos hídricos. Naquele mesmo ano a Secretaria Estadual de Recursos Hídricos, com o apoio dos demais órgãos do Sistema Integrado, instalou 20 Comitês de Bacias no Estado nas 22 Unidades de Gerenciamento de Recursos Hídricos - UGRHIs em que foi dividido o Estado (Figura 4). 


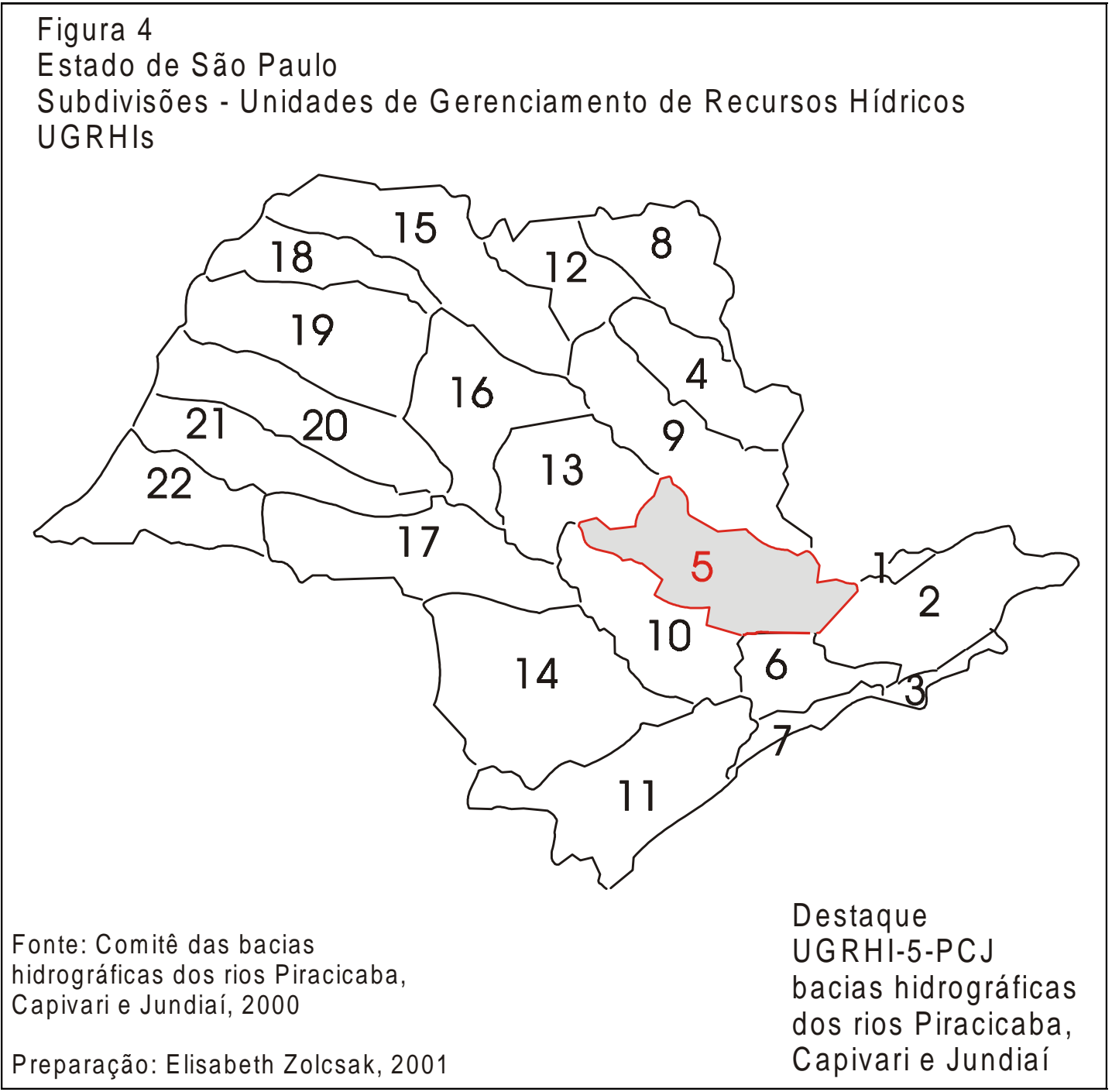

Os números na figura acima indicam as bacias hidrográficas, nomeadas como:

1Mantiqueira; 2Paraíba do Sul; 3Litoral Norte (LN); 4Pardo (Pardo); 5Piracicaba/Capivari/Jundiaí (PCJ); 6Alto Tietê (AT); 7Baixada Santista (BS); 8Sapucaí- Mirim /Grande (SMG); 9Mogi (Mogi); 10Sorocaba e Médio Tietê (SMT); 11Ribeira do Iguape e Litoral Sul (RB); 12Baixo Pardo/Grande (BPG); 13Tietê/Jacaré (TJ); 14Alto Paranapanema (ALPA); 15Turvo Grande (TG); 16Tietê/Batalha (TB); 17Médio Paranapanema (MP); 18São José dos Dourados (SJD); 19Baixo Tietê (BT); 20Aguapeí; 21Peixe; 22Pontal do Paranapanema (PP) 
Quanto ao saneamento, foi criado o Conselho Estadual de Saneamento - CONESAN.

O CONESAN, composto por 36 membros, 12 representantes do Executivo Estadual, 12 representantes de Governos Municipais e 12 representantes da Sociedade Civil, instalado em 1997, optou pela integração dos Sistemas Estaduais de Saneamento e de Recursos Hídricos em suas estruturas de âmbito regional. Propôs utilizar como estrutura regional do Sistema Estadual de Saneamento, a estrutura já instalada do Sistema Integrado de Gerenciamento dos Recursos Hídricos - SIGRH .

Em 1997, em cada Comitê de Bacia Hidrográfica - CBH, foi instalada uma Câmara Técnica de Saneamento.

Os Comitês de Bacia Hidrográfica são órgãos técnicos para direcionamento político e a Secretaria Estadual de Recursos Hídricos, Saneamento e Obras é a responsável política e executiva pelos recursos hídricos, usos, conservação e recuperação, pelos efluentes líquidos e resíduos sólidos gerados pelas populações. Trabalha em conjunto com o DAEE - Departamento de Águas e Energia Elétrica (autarquia responsável pela outorga para utilização de recursos hídricos no Estado), a SABESP Companhia de Saneamento Básico do Estado de São Paulo, e a CPOS Companhia Paulista de Obras e Serviços.

O município de Vinhedo está na região abrangida pela Unidade de Gerenciamento de Recursos Hídricos 5 do Estado de São Paulo, Unidade esta que compreende as bacias hidrográficas dos rios Piracicaba, Capivari e Jundiaí.

Em 1986 a CETESB - Companhia de Tecnologia de Saneamento Ambiental do Estado de São Paulo realizou trabalhos de acompanhamento e projeções na bacia do rio Piracicaba, especificamente na área ocupada por um conjunto de 13 municípios nucleados em função do binômio JundiaíCampinas. 
Tais municípios, integrados, quase fundidos em termos físicos e espaciais e complementares em termos sociais e econômicos, foram:

- Campo Limpo Paulista, Várzea Paulista, Jundiaí, Louveira, Vinhedo, Valinhos, Campinas, Sumaré, Nova Odessa, Americana, Santa Bárbara do Oeste, Paulínia e Indaiatuba.

A questão da água para abastecimento público já se mostrava como crítica, principalmente em função da exportação das águas de boa qualidade para a Região Metropolitana de São Paulo através do Sistema Cantareira.

O trabalho da CETESB (1986) adotou sub-bacias como unidade de análise e estabeleceu:

- áreas de esgotamento - constituindo-se de sub-bacias ou trechos de bacias que deveriam receber um tratamento de seus efluentes urbanos e industriais a fim de garantir a qualidade das águas a jusante; incluiriam toda a área de crescimento urbano das sedes municipais;

- áreas de preservação máxima - constituindo-se de mananciais municipais e regionais cujas características de uso e ocupação do solo não comprometeriam a qualidade das águas para consumo público se a urbanização das sedes municipais existentes nestas áreas ficasse contida nas áreas de esgotamento;

- áreas de restrição e controle - com necessidade de controle máximo quanto às fontes poluidoras de água, pontuais e dispersas, já implantadas e restrição quanto a novas atividades.

De acordo com o mesmo relatório da CETESB, o segmento constituído pelos municípios de Louveira-Vinhedo-Valinhos, em 1986, ainda não estava maciçamente urbanizado apresentando ocupação mista, com chácaras servindo de residência temporária, áreas de moradia permanente, e sítios produtivos hortifrutíferos. Louveira pertence à bacia do Capivari; Vinhedo e Valinhos estão na bacia do Atibaia, sub-bacia do rio Piracicaba. 
Vinhedo apresentava como mananciais de captação o córrego Cachoeira e Alagado alimentando a Represa I, o córrego Cachoeira alimentando a Represa II, a Represa do Pinheirinho (afluente do córrego dos Pinheiros) e o córrego Bom Jardim. Estes mananciais locais são afluentes do Rio Atibaia.

Como corpos receptores de efluente urbano estavam o córrego dos Pinheiros e o córrego Cachoeira.

O trabalho da CETESB recomendava que as sub-bacias de captação dos municípios de Bom Jesus dos Perdões, Jarinu, Vinhedo e Valinhos deveriam constituir áreas de preservação máxima; as áreas urbanas de Atibaia, Itatiba, Vinhedo e Valinhos deveriam ficar restritas às áreas de esgotamento; os esgotos urbanos e industriais de Atibaia, Itatiba, Vinhedo, Valinhos e Campinas deveriam ser tratados antes de atingirem o rio Atibaia; o restante deste trecho da bacia do rio Piracicaba deveria constituir área de restrição e controle.

Em relação à bacia do rio Capivari, das nascentes até a captação de Campinas, ou seja, em áreas dos municípios de Louveira, Campinas, Valinhos, Vinhedo e Itupeva, a CETESB também recomendava restrição e controle. Considerando as captações de Campinas, trazia como prioritário o tratamento avançado dos efluentes urbanos e industriais de Vinhedo e Valinhos.

Aquele estudo concluía que "a bacia do Rio Piracicaba é uma área de produção de grandes quantidades de água de boa qualidade, porém sua exportação para a Região Metropolitana de São Paulo, através do Sistema Cantareira, deixa os rios com vazão mínima, agravando os efeitos de poluição e colocando em perigo o futuro abastecimento da Região Campineira" (CETESB, 1986). E que "Vinhedo, Valinhos e Indaiatuba têm mananciais locais que talvez não resistam à pressão decorrente da urbanização, demandando água dos corpos principais onde já existem captações" (id. ib.). 
Um estudo mais recente, o Relatório Técnico Final do Comitê das Bacias dos Rios Piracicaba, Capivari e Jundiaí (2000a), destaca que a UGRHI 5 é uma região industrial, com problemas ambientais decorrentes da poluição dos corpos d'água, principalmente por esgotos não tratados.

A situação de demanda de água é crítica em toda a região.

Os sistemas de abastecimento de água desta região - Bacias Hidrográficas dos rios Piracicaba, Capivari e Jundiaí - atendem a cerca de 3.500.000 habitantes. O total de água demandada hoje para uso doméstico é de $14,9 \mathrm{~m}^{3} / \mathrm{s}$, sendo o consumo efetivo de $9,3 \mathrm{~m}^{3} / \mathrm{s}$ ( $64 \%$ da demanda). Perdas físicas correspondem a $2,7 \mathrm{~m}^{3} / \mathrm{s}$ ( $18 \%$ da demanda) e ocorrem outras perdas - perdas não físicas - que são partes utilizadas pelos consumidores mas não registradas nas micromedições.

A demanda atual de água para uso industrial é de $17,3 \mathrm{~m}^{3} / \mathrm{s}$, sendo que dez grandes usuários são responsáveis pela retirada de $74 \%$ deste total: Ajinomoto Ind. Com. Ltda., Butilamil Ind. Reunidas, Cia. Paulista de Força e Luz, Cia. Antarctica Paulista Ind. Bras. Bebidas, Petrobras-Replan, Rhodia do Brasil, Ripasa S.A., União São Paulo - Agricultura Ind. Com., Usina Açucareira Ester, Usina Santa Helena S.A. Açúcar e Álcool.

A projeção das demandas, em $\mathrm{m}^{3} / \mathrm{s}$, se configura como:

\begin{tabular}{l|r|r|r}
$\begin{array}{l}\text { tipo de uso } \\
\text { abastecimento } \\
\text { público }\end{array}$ & $14,9(37,2 \%)$ & $18,1(38,9 \%)$ & $21,1(41,1 \%)$ \\
\hline uso industrial & $17,3(43,1 \%)$ & $19,6(42,1 \%)$ & $21,4(41,6 \%)$ \\
\hline uso agrícola & $7,9(19,7 \%)$ & $8,9(19,0 \%)$ & $8,9(17,3 \%)$ \\
\hline total $\mathrm{m}^{3} / \mathrm{s}$ & 40,1 & 46,6 & 51,4
\end{tabular}

Para a UGRHI 5 tem-se hoje uma exploração de $107,5 \%$ da vazão mínima e de $72,8 \%$ da vazão máxima, devendo atingir no ano de 2020 , $138,0 \%$ e $93,4 \%$ das vazões mínima e máxima, respectivamente. Estes valores indicam altos índices de reuso das águas e avançado estado de degradação. 
Em suas projeções, o Comitê das Bacias Hidrográficas dos rios Piracicaba, Capivari e Jundiaí considera como cenário de crescimento as tendências de desenvolvimento macro-econômico nacional e do Estado de São Paulo. Nestas tendências a região deverá absorver o processo de desconcentração econômica da Região Metropolitana de São Paulo, ter incremento de sua agroindústria e de seu segmento urbano resultando em taxa de crescimento superior à média estadual.

Foram consideradas densidades de saturação 65 hab/ha para as aglomerações urbanas de Campinas e Jundiaí e 60 hab/ha para o conjunto das demais cidades, representando um crescimento de cerca de $180 \%$ em relação às áreas urbanas do ano de 1999.

O potencial de recursos hídricos superficiais das bacias que compõem a UGRHI 5 - PCJ não está totalmente à disposição para uso na região pois uma parcela é revertida através do Sistema Cantareira para a bacia do Alto Tietê, respondendo, este Sistema, por $60 \%$ do abastecimento de água potável da Região Metropolitana de São Paulo.

Pelo cenário crítico dos recursos hídricos superficiais, ocorre na UGRHI 5 alta procura pelas águas subterrâneas que na região têm um potencial de vazão explotável total da ordem de $24,0 \mathrm{~m}^{3} / \mathrm{s}$.

O Comitê de Bacia Hidrográfica da área conhece o uso de águas subterrâneas para auto-abastecimento doméstico, consumo industrial e como complementar para o abastecimento público, mas não dispõe de dados maiores sobre problemas de rebaixamento dos aqüíferos (CBH-PCJ, 2000a: 43).

Além da demanda, a poluição dos corpos d'água compõe o cenário crítico na região. Os principais mananciais superficiais das sub-bacias e bacias que compõem a UGRHI 5 estão enquadrados nas seguintes classes de uso:

classe 1 - mananciais a montante das barragens do Sistema Cantareira; classe 2 - demais trechos e cursos de água não enquadrados nas classes 1 e 4;

classe 4 - rio Jundiaí, desde a área urbana de Jundiaí até a sua foz. 
Porém quase todos os trechos dos principais cursos de água apresentam elevados graus de degradação decorrentes de lançamentos de esgotos urbanos $\mathrm{e}$ industriais, resultando em enquadramentos correspondentes à classe 4 ou pior que a classe 4 .

A carga poluidora remanescente destes lançamentos é de 239 tDBO/dia, sendo que perto de $157 \mathrm{tDBO} / \mathrm{dia}$ tem origem nos esgotos domésticos e 82tDBO/dia nos efluentes industriais (CBH-PCJ-2000a: 45).

Para as águas subterrâneas, o Comitê afirma que ainda não se observam problemas mais sérios de degradação dos aqüíferos.

Como as cargas poluidoras oriundas dos sistemas de esgotos urbanos constituem a principal fonte de degradação dos recursos hídricos superficiais, o combate a estas fontes é prioridade para a área.

Há necessidade de tratamentos secundários em todas as comunidades, mas a implantação destes tratamentos foi prevista em duas etapas, com o horizonte para o ano de 2010.

A primeira etapa objetiva implantar, até 2005, tratamento em 38 sistemas de esgotos em 34 municípios, sendo 12 deles de tratamento primário e 26 de tratamento secundário. As Estações de Tratamento de Esgotos com tratamento primário deverão ser complementadas para tratamentos secundários após 2005.

O tratamento de esgotos urbanos reduzirá as cargas poluidoras em 47,1\% em 2005, 82,3\% em 2010 e 82,9\% em 2020.

Quanto aos esgotos industriais, o Comitê (CBH-PCJ, 2000a: 86) traz dados da CETESB, de 1998, indicando que a região da UGRHI 5 contava com 288 indústriais com cargas poluidoras potenciais orgânicas de 598,8 tDBO/dia e inorgânicas de 4,83 tDQO/dia, e cargas poluidoras remanescentes de 82,4 tDBO/dia e 0,7 tDQO/dia, orgânica e inorgânica, respectivamente.

Ou seja, os tratamentos dos esgotos industriais removem, em média geral, $86,2 \%$ das cargas orgânicas e $85,7 \%$ das inorgânicas. 
Mas algumas indústrias apresentam índices de remoção superiores a $90 \%$ enquanto outras não tratam seus efluentes. Caso tratassem, no mínimo em $80 \%$, a carga poluidora remanescente seria reduzida em cerca de $20 \%$, passando para 66,4 tDBO/dia.

São grandes fontes poluidoras 40 estabelecimentos industriais que representam $14 \%$ das indústrias consideradas e são responsáveis por $27,4 \%$ e $79,1 \%$ das cargas orgânicas potenciais e remanescentes dos esgotos industriais do UGRHI 5. Destes 40, 13 indústrias não tratam seus efluentes respondendo por $47,9 \%$ da carga industrial remanescente total da região.

A atual carga industrial remanescente total de $82,4 \mathrm{tDBO} /$ dia equivale a uma população de cerca de 1.500 .000 habitantes e deve ser necessariamente minimizada.

Sobre as fontes difusas de poluição, entre elas as emanações gasosas de combustão provocando chuvas ácidas e os produtos químicos utilizados na agricultura, não existem dados concludentes.

Neste cenário crítico, a cidade de Vinhedo tem suas captações atuais no córrego Cachoeira e no rio Capivari. A outorga atual do DAEE para o município é de $985 \mathrm{~m}^{3} / \mathrm{h}$, havendo perda de $33 \%$ na água tratada (segundo informações verbais da Secretaria de Água e Esgoto reproduzidas pelo Jornal de Vinhedo em edição de 28/04/2001).

O plano proposto pelo Comitê das Bacias Hidrográficas da região prevê a desativação da captação do rio Capivari, em razão da deterioração de qualidade de suas águas (Louveira lança esgotos a montante) e da perspectiva de redução da disponibilidade assim que Louveira implantar sua captação nesse manancial. O novo manancial deverá ser o rio Atibaia, no qual serão captados $274 \mathrm{l} / \mathrm{s}$ no final do plano (CBH-PCJ, 2000a: 53).

Quanto à qualidade das águas, considerando rios relacionados com Vinhedo, o rio Atibaia apresenta maior concentração de coliformes fecais e fosfato total do que permite seu enquadramento (classe 2).

O rio Capivari também tem parâmetros de Oxigênio Dissolvido, DBO, coliformes totais e fosfato total bastante desviados dos padrões aceitáveis. 
Também em Vinhedo é intensa a discussão sobre poços artesianos. O risco é o depressionamento do aqüífero que deve ser utilizado com poços pelo sistema de recarga, ou seja, com perfurações até onde a água da chuva é jogada. Por este sistema o Aqüífero Cristalino teria vazão média de $30 \mathrm{~m}^{3} / \mathrm{h}$ em locais que têm barragens para evitar depressionamento.

Os poços que já foram perfurados em Vinhedo estão em áreas consideradas APP - Áreas de Preservação Permanente - situadas às margens de córregos, como o Cachoeira. A empresa contratada para as perfurações (Constróli) deve plantar árvores para recuperar as Áreas de Preservação Permanente, mas isto até agora não ocorreu.

Estão registrados 65 poços artesianos ativos, com produção de 5 $\mathrm{m}^{3} / \mathrm{h}$, mas o DAEE (Departamento de Águas e Energia Elétrica, do Estado de São Paulo) acredita em mais de 100 poços perfurados em Vinhedo.

Quanto aos esgotos, a rede em Vinhedo atende $80 \%$ da população urbana da região. Porém grandes condomínios de alto padrão, como Marambaia e São Joaquim na bacia do rio Capivari, não têm rede de esgotos, utilizando fossas sépticas. O único destes condomínios de alto padrão em Vinhedo que está realizando obras de rede de esgotos para ser ligada a Estação de Tratamento de Esgotos da bacia do córrego dos Pinheiros é o Condomínio Vinhas da Vista Alegre, atualmente com 1059 lotes e 850 casas.

Estão propostas duas Estações de Tratamento de Esgotos - ETEs.

A ETE Pinheirinho lançará no ribeirão dos Pinheiros, bacia do rio Atibaia, $70 \%$ dos esgotos urbanos de Vinhedo tratados pelo sistema de lodo ativado com aeração prolongada.

Outra ETE, proposta para a bacia do rio Capivari, tratará $30 \%$ dos efluentes domésticos de Vinhedo em lagoa anaeróbica.

Além dos aspectos anteriores, que se referem à degradação e esgotamento de recursos hídricos, queremos trazer alguns dados sobre a disposição de resíduos sólidos, degradação de áreas verdes e excesso de loteamentos, para completarmos este painel sobre Vinhedo. 


\subsubsection{Resíduos sólidos, áreas verdes e loteamentos}

O Comitê das Bacias Hidrográficas da região afirma em seu Relatório (CBH-PCJ, 2000a: 489) que a "...coleta urbana de lixo é boa, atendendo à totalidade das populações locais, excetuando-se as cidades de Campo Limpo Paulista, Hortolândia, Indaiatuba, Jarinu, Pedra Bela, Rio das Pedras e Vinhedo".

Vinhedo recolhe 15,19 t de lixo/dia destinadas a aterro intermunicipal que está com a atual condição controlada mas já sugerindo nova área, conforme relatado no Inventário Estadual de Resíduos Sólidos Domiciliares da Secretaria do Meio Ambiente e CETESB em 1998. A coleta de lixo domiciliar é convencional, com caminhões compactadores, e sua destinação final é o Aterro Sanitário de Várzea Paulista.

Os municípios de Vinhedo, Jundiaí, Cajamar, Campo Limpo Paulista, Louveira e Várzea Paulista, compondo um Consórcio Intermunicipal para Aterro Sanitário, estão discutindo novos locais para a deposição do lixo, pois a problemática do tempo de vida do aterro já está sendo enfrentada.

O descaso com áreas verdes, como em todo o Estado, também aparece em Vinhedo, resultado de práticas agrícolas passadas com o uso de extensas derrubadas e queimadas, da perda de importância econômica da agricultura, da alta taxa de urbanização da população e da expansão da mancha urbana através de loteamentos.

Excessivos loteamentos no município, além da ocupação de áreas, têm trazido também problemas de assoreamento de córregos, pelo movimento de terras e perda de matas ciliares, causando enchentes em algumas áreas mas, principalmente, comprometendo os mananciais.

Os grandes condomínios, considerados de médio/alto padrão, com lotes com área média de $1000 \mathrm{~m}^{2}$, estão entre estes loteamentos. Citandoos, para indicar suas grandezas, são:

Condomínio São Joaquim - 679 lotes

Condomínio Chácaras do Lago - 316 lotes

Condomínio Estância Marambaia - 1800 lotes

Condomínio Vinhas da Vista Alegre - 1059 lotes 


\subsubsection{Ações para melhoria e preservação ambiental da região de}

Vinhedo

Como os Comitês de Bacia Hidrográfica são órgãos para direcionamento político e administrativo que se valem de estudos técnicos ou acadêmicos, é de interesse apontar os objetivos de curto prazo do Plano de Bacia 2000/2003 do Comitê das Bacias dos rios Piracicaba, Capivari e Jundiaí (CBH-PCJ, 2000b).

Estes objetivos são:

- desenvolvimento técnico e institucional e estruturação das entidades e órgãos de gestão dos recursos hídricos;

- capacitação técnica de recursos humanos;

- implantação do sistema de cobrança pelo uso da água;

- atendimento de $98 \%$ da população urbana pelos sistemas de abastecimento de água;

- redução para $25 \%$ dos índices de perdas dos sistemas de abastecimento de água;

- atendimento de $92 \%$ da população urbana com coleta de esgotos;

- remoção de 47\% da carga poluidora dos esgotos urbanos;

- remoção de no mínimo $80 \%$ da carga poluidora dos efluentes industriais em todas as indústrias;

- controle de fontes difusas;

- economia de água pela racionalização dos usos;

- implantação de programas de conservação do solo e de proteção dos mananciais (estudos e projetos de drenagem, reflorestamento e recomposição da vegetação ciliar, proteção e conservação de ecossistemas aquáticos, rede hidrológica e de monitoramento da qualidade das águas);

- melhoria e controle das disposições dos resíduos sólidos;

- recuperação de áreas degradadas críticas;

- melhoria da educação ambiental em relação aos recursos hídricos. 
Em plano adicional, como o foco deste nosso trabalho é a difusão de conhecimento sobre 0 meio ambiente, também registramos as recomendações daquele Comitê relacionadas com a informação e atuação da população (CBH-PCJ, 2000b).

Assim, o Comitê de Bacia Hidrográfica dos rios Piracicaba, Capivari e Jundiaí:

- para o controle da erosão urbana, propõe campanhas de esclarecimento sobre as conseqüências danosas de intervenções e obras capazes de promover ou estimular processos erosivos;

- para o controle da erosão rural, sugere ampliação do programa de educação e esclarecimento com relação à conservação e manejo adequado dos solos de modo a minimizar as perdas de terras férteis por erosão e reduzir os custos com a manutenção da fertilidade dos solos, importantes para as atividades agropecuárias da região;

- para recuperação e conservação da qualidade das águas superficiais, prevê programa integrado (reflorestamento + conservação do solo + educação ambiental) nas áreas das cabeceiras das micro-bacias;

- para educação ambiental e sanitária, propõe a obrigatoriedade de programas em nível curricular, nas escolas de ensino fundamental e médio da rede escolar, incluindo o tema nos currículos das diversas disciplinas e no projeto pedagógico de cada escola e prevê a programação de eventos visando ao aprimoramento dos professores e técnicos na área ambiental, bem como à mobilização, organização e conscientização das comunidades em relação aos assuntos ambientais.

Veremos que as ações da Prefeitura Municipal de Vinhedo em relação aos problemas ambientais descritos seguem as diretrizes do Comitê das Bacias Hidrográficas da região. 


\subsubsection{Ações ambientais da Prefeitura Municipal de Vinhedo}

Como importante ação ambiental, a Prefeitura Municipal de Vinhedo está implantando a Estação de Tratamento de Esgoto Pinheirinho para lançamento de esgotos tratados no córrego dos Pinheiros, afluente do rio Atibaia.

Inaugurada no final de 2001, a ETE Pinheirinho está localizada na divisa de Vinhedo com o município de Valinhos em uma área de 30 mil metros quadrados. Receberá e tratará $70 \%$ dos esgotos, predominantemente domésticos, da área urbana da sede do município evitando o despejo inadequado nos córregos Pinheiros, Cachoeira, Esterzeck, Três Irmãos e do Bosque.

A Estação tratará 140 litros/segundo e o seu projeto de implantação prevê também o plantio de mata ciliar ao longo do córrego dos Pinheiros.

Os 30\% restantes de esgotos serão tratados a partir do primeiro semestre de 2002 na bacia do Capivari, onde será construída a Estação de Tratamento de Esgoto Capivari conforme Termo de Compromisso de Ajustamento de Conduta feito entre o Ministério Público do Estado de São Paulo, a CETESB e a Prefeitura Municipal de Vinhedo.

Ainda enfocando recursos hídricos, a Prefeitura colabora, através de sua Secretaria de Planejamento e Meio Ambiente, com o Programa de Educação Ambiental "Semana da Água", aplicado e coordenado regionalmente pelo Consórcio Intermunicipal das Bacias dos Rios Piracicaba e Capivari desde 1996.

Deste Programa, participam escolares, professores e grupos comunitários.

A Secretaria de Planejamento (SEPLAN) de Vinhedo absorveu a Seção de Meio Ambiente apenas em 1999. Anteriormente a Seção pertencia à Secretaria de Água e Esgoto, mas sem função definida. Hoje esta Seção procura atuar em Educação Ambiental, no incentivo à coleta seletiva de lixo e na orientação à conservação de praças. Mas tem também se voltado para a recuperação de áreas degradadas e proteção de áreas naturais. 
Para resíduos sólidos, a administração pública de Vinhedo vem desenvolvendo um Projeto Piloto de Coleta Seletiva.

Iniciado na Vila João XXIII, tendo envolvimento com escolas, creches e associações civis locais, o projeto já atinge $40 \%$ da cidade, porém a quantidade recolhida de material reciclável representa menos de $1 \%$ de todo o lixo produzido pelo município.

Os materiais coletados são triados em uma Central e vendidos na própria cidade ou região para intermediários, sendo a renda revertida para as pessoas que trabalham na separação final do material.

$\mathrm{Na}$ mesma área da Central de Triagem está sendo implantada a Usina de Reciclagem de Resíduos de Construção Civil.

Pelo seu plano, a Central de Triagem e Reciclagem de Resíduos Sólidos Urbanos possuirá quatro setores: Recicláveis Básicos (Programa de Coleta Seletiva), Grandes Volumes Aproveitáveis (Programa Cata Bagulho), Entulhos de Construção Civil e Fábrica de Blocos.

Pretende-se que o entulho (restos de argamassa, tijolos, blocos, telhas e pisos) que, atualmente, é com freqüência depositado irregularmente em Áreas de Preservação Permanente (APPs), ao longo dos córregos, retorne ao processo construtivo após processamento na Usina, como substituto de pedra, areia e arenitos e como blocos, guias e sarjetas que serão ali produzidas.

Estes projetos estão sendo desenvolvidos e executados pelas Secretarias Municipais de Planejamento e Meio Ambiente, Assistência Social, Educação, Habitação, pelo Centro Comunitário de Vinhedo e representantes dos trabalhadores da Central de Triagem.

Para conservacão de praças e jardins públicos a Secretaria de Planejamento e Meio Ambiente instituiu em 1997 o Programa "Adote uma Área Verde", para empresas ou instituições de ensino da rede particular.

Em relação a áreas naturais, a mesma Secretaria desenvolve o Plano de Revegetação da Mata Ciliar do rio Capivari para formar e regenerar a vegetação nas Áreas de Preservação Permanente ao longo do curso deste rio no município de Vinhedo. 
A revegetação, em uma extensão de aproximadamente $12 \mathrm{Km}$, objetiva atrair a fauna local para as áreas que hoje se apresentam degradadas.

O plano pretende ainda estimular outros municípios e formar um corredor verde ao longo dos $180 \mathrm{~km}$ deste rio, da nascente em Jundiaí até a foz no rio Tietê.

Para replantio há necessidade de orientação e aprovação do Departamento Estadual de Proteção dos Recursos Naturais (DEPRN) Equipe Técnica de Jundiaí, além da participação de empresas, condomínios, proprietários de terras e instituições parceiras para doação de mudas, contratação de mão-de-obra e conservação das áreas recuperadas.

De acordo com o Balanço Ambiental (SEPLAN, 2000) feito pela Secretaria de Planejamento e Meio Ambiente de Vinhedo, o Plano de Revegetação Ciliar do rio Capivari está dividido em quatro trechos, totalizando aproximadamente 36 hectares de área de preservação permanente, o que corresponde ao plantio de cerca de 58 mil árvores.

O primeiro trecho - Trecho 1 (São Joaquim) - corresponde a uma área pública de aproximadamente 3 hectares que margeia o rio Capivari nos limites do Condomínio Morada dos Executivos "Fazenda São Joaquim" e foi revegetado de dezembro/1999 a fevereiro/2000.

O Trecho 2 (Trevo) tem uma área estimada em 10,5 hectares, atravessando sítios e cerâmicas. A revegetação está sendo executada pela Prefeitura mas esta busca recursos externos além do apoio dos moradores da região.

O Trecho 3 (Industrial) e o Trecho 4 (Fazendas) estão em fase de levantamento dos dados de todas as propriedades cortadas pelo rio.

Outra ação voltada para áreas naturais é a Operação Mata-Fogo.

Desenvolvido a partir do segundo semestre de 2000 pela Prefeitura Municipal de Vinhedo, Embrapa Monitoramento por Satélite (Campinas), Corpo de Bombeiros e Polícia Florestal e de Mananciais, o Plano de Prevenção de Incêndios nas Matas Nativas de Vinhedo - Operação MataFogo objetiva a prevenção de incêndios florestais, e seu combate eficiente, nos remanescentes existentes naquele município. 
As atividades que estão sendo executadas são: o mapeamento e cadastramento de todas as matas do município, seus proprietários e/ou responsáveis; mapeamento das vias de acesso para combate a focos de incêndio; orientação da população sobre medidas preventivas e de combate a incêndios florestais; implementação de um sistema de monitoramento aéreo e terrestre; e treinamento de combate a incêndios.

Este painel do 'espaço' que tomamos para estudo nos auxilia, a seguir, a discutir o modelo acadêmico de meio ambiente.

\subsubsection{O modelo acadêmico de ambiente}

Não encontramos, em busca bibliográfica, estudos ecológicos específicos para o município de Vinhedo mas nos pautamos pelos documentos institucionais públicos apresentados para discutir sobre o modelo acadêmico de meio ambiente.

Nos documentos se destacam os problemas que estão recebendo atenção de órgãos regionais e municipais: degradação e esgotamento de recursos hídricos, disposição de resíduos sólidos, degradação de áreas verdes, excesso de loteamentos e movimentos de terra.

Verificamos que o modelo acadêmico de meio ambiente aplicado para Vinhedo trata de uma área com zona urbana, com ocupação horizontal e em adensamento, zona rural com extenso cultivo e desproteção do solo, assoreamento, poluição e superexploração de córregos e rios.

É uma representação simplista, mesmo quando redigida com as características fisiográficas e demográficas da localidade.

Cidades materializam as atividades humanas de habitar, trabalhar e trocar, fazendo uso das características físicas dos espaços, mas além disto representam contextos culturais e sócio-econômicos das comunidades. Representam interpretação do meio.

Em termos ecológicos, cidades representam ecossistemas nos quais a energia flui, através da parte biológica do sistema, e os materiais circulam no interior do sistema ou entre sistemas ligados. 
Mas o viver humano também necessita de ar puro, água limpa para beber e para finalidades contemplativas e estéticas, de tampões climáticos e escapes psicológicos fornecidos pelas massas de água e de vegetação.

Ou seja, ecossistemas urbanos não são caixas de entrada-saída de energia e entrada-circulação-saída de materiais. Melhor dizendo, são apropriações do meio natural.

Lajeunesse et al. (1995) propõem que ecossistemas naturais - no sentido de silvestres, e não rurais ou urbanos - podem ser avaliados e manejados combinando-se o conceito de valor biótico da vegetação e fauna com o conceito de fragilidade abiótica do solo, resultando na criação de um mapa de sensibilidade que pode ser usado por planejadores e em manejo.

Como exemplo, vejamos os ecossistemas litorâneos, de restinga e mangue, ambos com alto valor biótico da vegetação e fauna por abrigar espécies únicas e com fisiologia extremamente adaptada às condições de salobridade, e ambas com fragilidade abiótica dos solos formados pelo movimento das marés e ventos. Logicamente são ecossistemas sensíveis e vulneráveis a intervenções.

Cidades se formam sobre ecossistemas naturais, mas geralmente substituindo-as, trazendo assim para uma escala maior os possíveis mapas de sensibilidade, onde cabem os exemplos de perda de mananciais e de matas ciliares.

Aqui se aplica a preocupação apontada por Szaro et al. (1998) em torno da necessidade de conhecimento da estrutura ecológica, processos, variabilidade natural, vulnerabilidade e potencial de recuperação, em múltiplas escalas de espaço e tempo, no manejo de ecossistemas. Não abordam ecossistemas urbanos mas podemos incluí-los.

O trabalho de Poiani et al. (1998) apresenta uma visão mais operacional, que utiliza um diagrama de fluxo, para o planejamento da conservação de um sítio, sendo:

definição de objetivos de conservação -> aquisição de informações ecológicas, incluindo o contexto humano -> avaliação de ameaças -> estratégias de conservação -> implementação do plano. 
$\mathrm{Na}$ coleta de informações ecológicas estes autores utilizam diagramas ecológicos conceituais, considerados úteis para resumir informação biológica complexa.

Freqüentemente constroem diagramas conceituais simples sobre estado/transição:

causas e conseqüências da diminuição desta população <---- população atual de alguma espécie ----> causas e conseqüências do aumento desta população

$\mathrm{Na}$ análise do contexto humano, estes mesmos autores utilizam: as características demográficas (estrutura, crescimento), econômicas (taxa de emprego, custo de vida), da terra (propriedades, zoneamento, uso do solo), do governo (governo local, política), das atitudes culturais e valores.

Após a avaliação de riscos, constróem diagramas situacionais para visualização de interrelações entre os componentes da situação e para planejamento das estratégias conservacionistas.

Encontramos caracterizações para Vinhedo e avaliação de ameaças voltada para o provimento de água e manutenção de áreas com vegetação natural, mas dentro de uma política pontual.

O trabalho de Franco (1997: 132) sugere, para conjunturas assim, o instrumento do Desenho Ambiental, que projeta cenários hipotéticos com princípios de conservação ambiental objetivando a melhoria da qualidade de vida e o desenvolvimento sustentado.

Seriam cenários, por exemplo, que respeitassem a topografia para manutenção de microclima e de recursos hídricos e que mantivessem a organização da flora e fauna de uma localidade.

O Desenho Ambiental assim posto orienta as intervenções antrópicas no território incluindo no planejamento da ocupação os pontos de maior significado visual, os aspectos críticos de transformação do relevo, do solo e da cobertura vegetal (Franco, 1997: 138).

Todas estas observações, sobre os aspectos ambientais de Vinhedo considerados relevantes pelos órgãos públicos da região e município e sobre os aspectos que direcionam planejamento e manejo ambiental, nos levam novamente a destacar o conceito de ecossistema urbano e o conceito de cidade com sustentabilidade. 
Este conceito de cidade com sustentabilidade está voltado atualmente para os problemas de segregação sócio-espacial.

Discutindo os sentidos da sustentabilidade urbana, Acselrad (2001) aponta a proposição central da busca de eficiência no uso de recursos.

Uma eficiência que tem se tornado monetarizada mas que se depara com limites ecológicos ou com a capacidade de suporte das regiões e do planeta e que só pode ser alcançada pela redução do nível de consumo ou do crescimento demográfico. Contradiz o crescimento econômico sempre ascendente presente no pensamento político atual.

Acselrad alinha esta proposição com uma representação técnicomaterial da cidade. Há consumo de espaço, energia e matérias-primas e produção de rejeitos.

Nesta representação a cidade sustentável é aquela que minimiza o consumo de energia, de outros recursos materiais e a produção de rejeitos com a mesma oferta de serviços.

Esta representação se distingue da ecossistêmica composta por movimentos interativos de circulação, troca e transformação de recursos, falíveis diante de rupturas nas condições materiais requeridas.

Acselrad (2001) continua comentando que, para muitos, o princípio da sustentabilidade seria a equidade social, distributiva, financeira, comercial e dos fluxos de tecnologia.

Para outros seriam as propostas de auto-suficiência das comunidades desenvolvendo relações tradicionais com o meio natural.

$E$, ainda para outros, que questionam as bases técnicas das cidades, ocorrem representações coletivas da cidadania urbana voltadas para os aspectos sanitários de emissões e efluentes, e para noções patrimoniais e de heranças, traduzindo conceitos de qualidade de vida.

\section{Completa que}

"a noção de cidade sustentável instaura uma nova cena de enunciação, onde uma trama de múltiplos personagens e falas entrecruzadas reelabora as representações da cidade. ... Três procedimentos simbólicos são acionados: o de refiguração do espaço através de uma imagem que articula os campos semânticos distintos da natureza e da cidade; o da reproblematização da ação através da aplicação de uma racionalidade científica ecológica ao urbano; o da reinstituição do tempo por novas formas de duração - patrimoniais - das coisas (Acselrad, 2001: 49). 
Assim, para Vinhedo, vimos uma representação técnico-material tateando rumo à eco-eficiência sem nela ter encontrado fortes defesas para a equidade social, identidade e memória.

\subsection{A empresa Unilever - Divisão Elida Gibbs}

O grupo empresarial anglo-holandês Unilever, presente em 150 países, se constituiu em 1929 com a união de empresas que produziam sabão e margarina desde os séculos XVIII e XIX.

Presente no Brasil desde aquela época, com a empresa Irmãos Lever, a Unilever comprou, em 1960, a Companhia Gessy Industrial, localizada em Valinhos, SP, para conquistar o mercado de produtos de limpeza e higiene pessoal. Pela força da marca, a Unilever incorporou o nome Gessy na razão social do grupo neste país que aqui passou a denominar-se Indústrias Gessy Lever Ltda..

Seus produtos, sabões e sabonetes das marcas Sunlight, Lux, Lever, Lifebuoy, Rinso e Omo, se tornaram bastante conhecidos.

Em 1970 a Gessy Lever ingressou no mercado brasileiro de alimentos com a margarina Doriana. Solidificou sua base neste mercado alimentício adquirindo a empresa Anderson Clayton (de óleos e margarinas) em 1986, a Cica (de conservas) em 1993 e a Kibon (de sorvetes) em 1997.

Numa reestruturação interna do grupo Unilever, por linha de produtos, surgiu a Divisão Elida Gibbs, de produtos de higiene pessoal e perfumaria, em maio de 1971 na Inglaterra, e em dezembro daquele mesmo ano no Brasil.

No primeiro semestre de 2001 as Divisões operacionais da Unilever no Brasil eram:

Divisão Elida Gibbs - de produtos de higiene pessoal e perfumaria;

Divisão Lever - de produtos de higiene e limpeza doméstica;

Divisão Van den Bergh - de produtos alimentícios;

Divisão Kibon - de sorvetes;

Divisão Diversey Lever - de produtos e serviços de higiene e limpeza para uso profissional (em postos de serviços, lavanderias, hospitais e indústrias alimentícias). 
Mas naquele período já estava em andamento a fusão da Divisão Elida Gibbs com a Divisão Lever resultando na HPC - Divisão "Home and Personal Care" - de higiene e beleza. Uniram-se as áreas administrativas e de suporte, ou seja, as áreas financeiras, comerciais, de distribuição, segurança, meio ambiente e qualidade, mas não as áreas de produção, ou seja, as fábricas.

No segundo semestre de 2001 a empresa intensifica o uso do nome Unilever e compõe as divisões Unilever Higiene e Beleza, Unilever Bestfoods, Kibon e Diversey Lever.

Para a fábrica de Vinhedo da Unilever (agora da divisão Unilever Higiene e Beleza e fabricante de produtos de higiene pessoal) mantemos 0 nome Elida Gibbs como era quando do início do nosso contato.

\subsubsection{Divisão Elida Gibbs - Unilever - em Vinhedo}

Em 1975 foi comprado um terreno de $111.719 \mathrm{~m}^{2}$ em Vinhedo, com incentivos fiscais da Prefeitura, para desafogar a fábrica da Unilever de Valinhos. Três anos depois, com a instalação de caldeiras a vapor, de sistema para tratamento de efluentes industriais e de programas de treinamento de recursos humanos, iniciou-se na nova fábrica a produção de produtos de higiene pessoal e perfumaria, como xampus, cremes dentais e desodorantes.

Os principais produtos e marcas desta fábrica, que listamos para apontar a inserção da empresa entre os consumidores, são:

Xampus: Seda, Organics, Dimension, All Clear ;

Cremes Dentais: Close-up, Gessy e Signal;

Cremes para a pele: Vasenol e Vinólia ;

Desodorantes: Axe, Rexona, Dove;

Sabonetes líquidos : Dove.

A Figura 5 (página seguinte) traz a localização da empresa no Distrito Industrial do município de Vinhedo. 


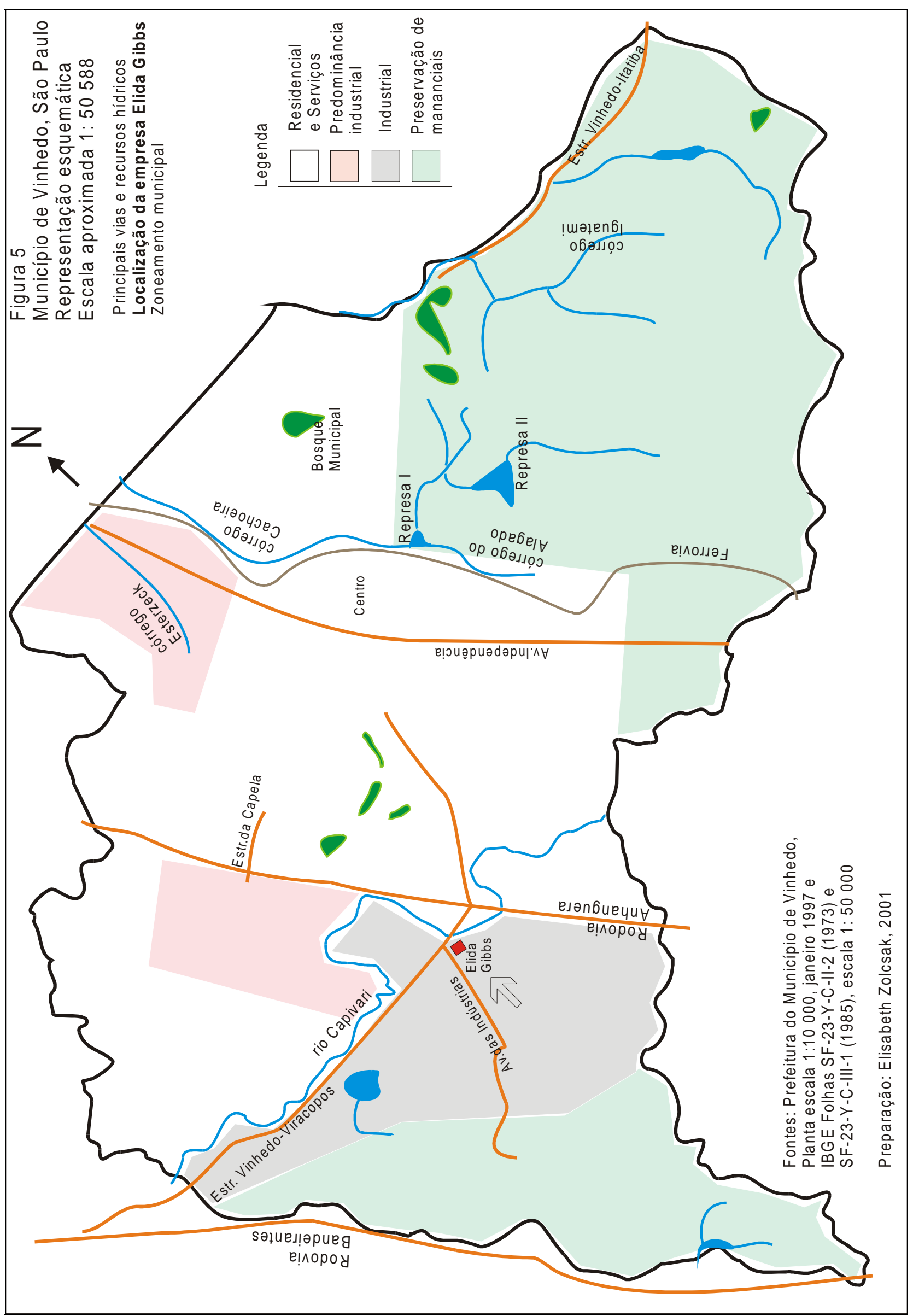


$\mathrm{Na}$ ocupação do espaço, a empresa apresenta setores administrativos, técnicos e produtivos ocupando um mesmo bloco construído e concentra áreas de armazenamento de matérias-primas, embalagens e produtos para distribuição em bloco anexo (Figura 6).

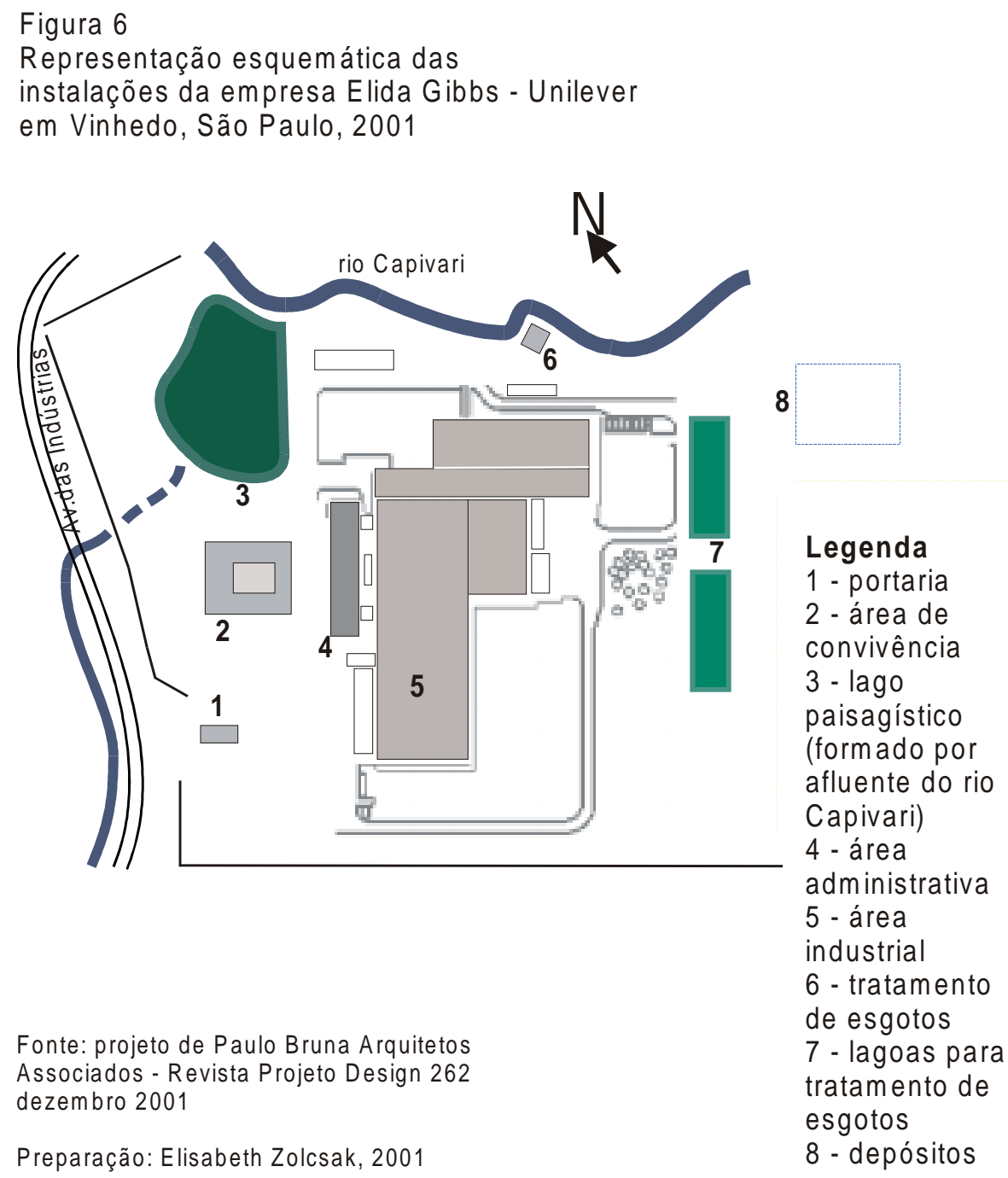

Legenda

1 - portaria

2 - área de

convivência

3 - lago

paisagístico

(formado por

afluente do rio

Capivari)

4 - área

administrativa

5 - área

industrial

6 - tratamento

de esgotos

7 - lagoas para

tratamento de

esgotos

8 - depósitos

Esta fábrica emprega em torno de 900 funcionários próprios. São 300 empregados em atividades administrativas, de pesquisa e desenvolvimento de produtos, embalagens e controle de qualidade, e 600 empregados nas linhas de produção e de apoio.

Os funcionários das linhas de produção estão divididos em 3 turnos (6-14 h, 14-22 h, 22-6 h). A empresa ainda absorve 180 trabalhadores em setores terceirizados para atividades de vigilância, limpeza e informática. 


\subsubsection{Relações com a comunidade e educação de funcionários}

A Unilever realiza projetos educativos, junto às comunidades dos municípios que sediam suas fábricas, voltados para tópicos sobre saúde e meio ambiente,

A fábrica (Elida Gibbs) de Vinhedo realiza o "Projeto D'Angola na Escola" direcionado à transmissão de conceitos sobre o meio ambiente para alunos de $1^{\underline{a}}$ a $4^{\underline{a}}$ séries do ensino fundamental das escolas daquela região. Envolve visitas à fábrica, palestras, atividades como "circuito ecológico", apresentação de teatro e cartilha (Figura 7).

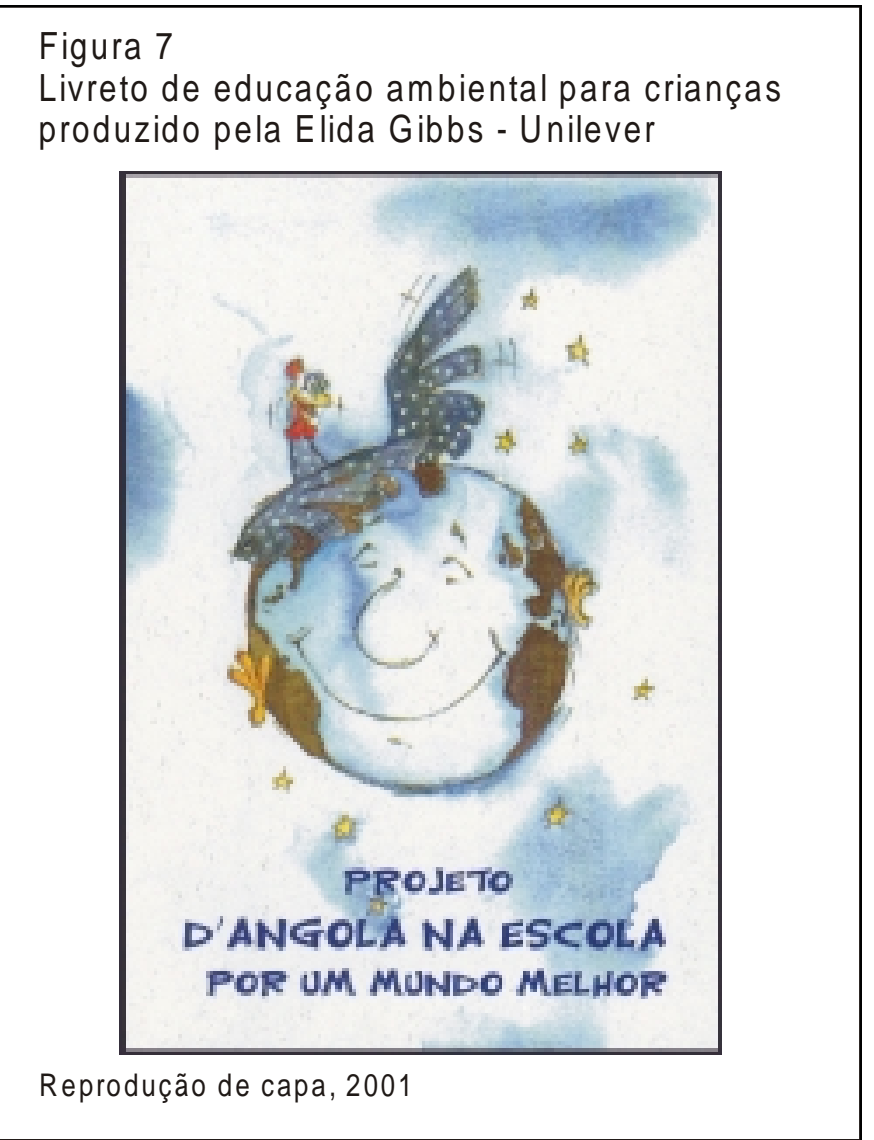

Junto à comunidade geral, ou junto a seus consumidores, a Elida Gibbs procura incentivar a coleta seletiva de lixo (Figura 8).

Em relação à educação de funcionários, a unidade da Unilever em Vinhedo tem implantado, desde 1995, o "Projeto Educare" com cursos supletivos de ensino fundamental e médio. Este Projeto prevê ainda o oferecimento de cursos profissionalizantes. 


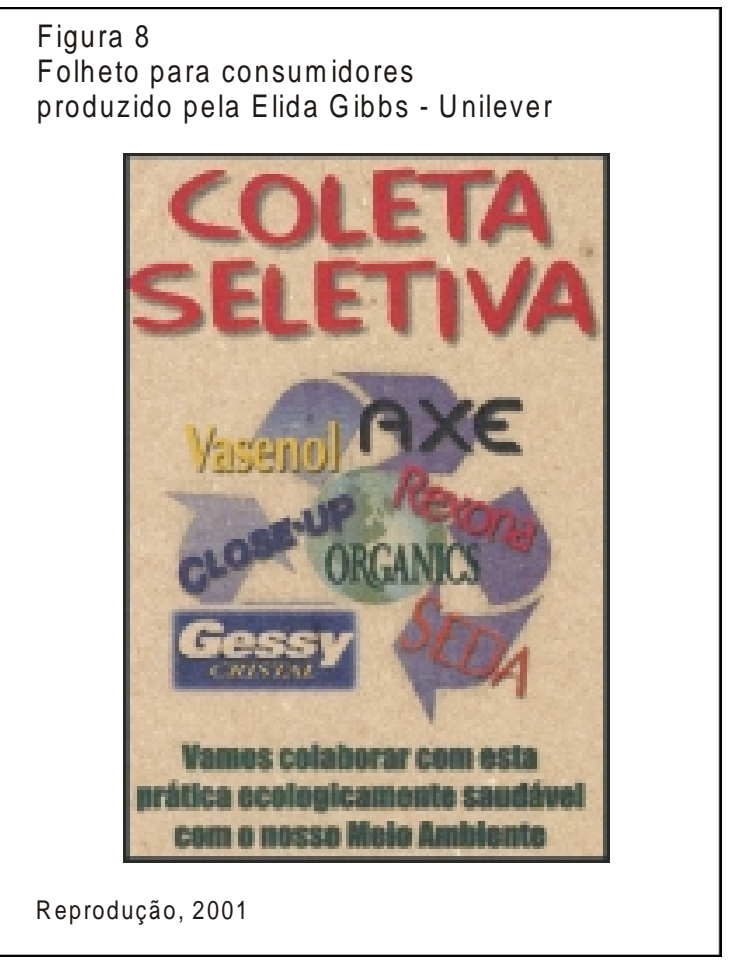

Como informativo da comunidade de funcionários e seus familiares, a Elida Gibbs em Vinhedo publica, desde 1995, o boletim mensal Folha Verde, impresso em papel reciclado. Este boletim traz notas sobre os programas de qualidade na produção, segurança no trabalho, saúde ocupacional e cuidados com o meio ambiente (Figura 9).
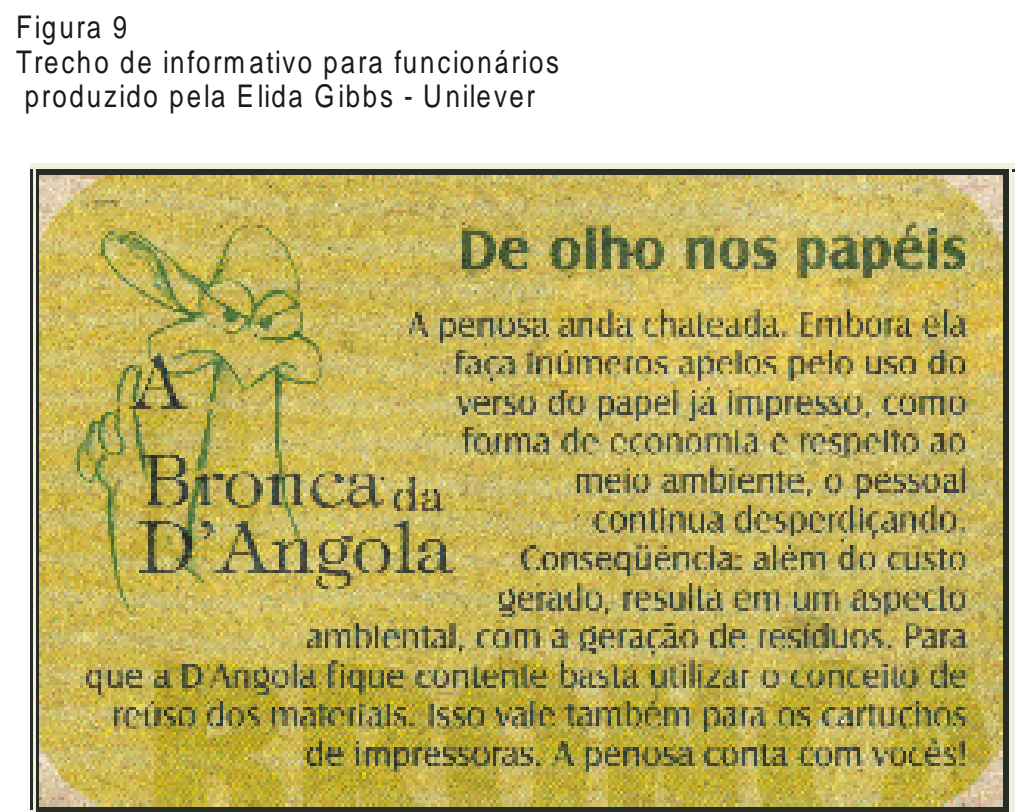

Reprodução, 2001 


\subsubsection{Aspectos ambientais gerais da indústria química}

O IBGE, em sua Classificação Nacional de Atividades Econômicas de 1994, cita a fabricação de sabões, detergentes e artigos de perfumaria como um grupo de atividades abrangidas pela fabricação de produtos químicos.

Considerando as matérias-primas empregadas na Elida Gibbs, além de seus produtos, abordamos aqui aspectos genéricos da fabricação de produtos químicos inorgânicos e orgânicos para trazer acréscimos à compreensão das questões ambientais que envolvem a fábrica de Vinhedo em sua cadeia produtiva.

$\mathrm{Na}$ indústria química inorgânica se destaca a fabricação de soda cáustica, cloro e de pigmentos inorgânicos. A produção de soda cáustica (hidróxido de sódio) e de cloro estão ligadas, sendo o processo mais usual a eletrólise de cloreto de sódio do mar ou de minas de sal gema.

Esta eletrólise pode ser feita em células a diafragma com uso de grafite ou titânio e de ferro, ou com uso de grafite ou titânio e de mercúrio. Os principais poluentes são o mercúrio metálico, líquidos residuais com ácido sulfúrico e precipitados de efluentes com sulfatos e carbonatos.

$\mathrm{Na}$ fabricação de pigmentos inorgânicos os processos à base de dióxido de titânio apresentam grandes problemas de poluição pela geração de efluentes ácidos dificilmente recuperáveis contendo ácido sulfúrico, sulfato ferroso, titânio, cádmio, vanádio, chumbo e cromo.

$\mathrm{Na}$ indústria química orgânica, especialmente na indústria petroquímica, produtora de grande parte da matéria-prima de indústrias com produtos de higiene pessoal, há geração de muitos tipos de resíduos, emissões e efluentes. Melhores processos podem reduzir, reutilizar e reciclar os despejos diminuindo sua carga para posterior tratamento.

Os despejos em geral se originam diretamente da produção, do funcionamento das caldeiras, de esgotos sanitários das instalações, de águas pluviais contaminadas, de acidentes, de lavagem e manutenção de equipamentos.

De modo geral, como potenciais impactos ambientais negativos temos que a indústria química emprega grande quantidade de água, para os produtos, processos, resfriamento e lavagem de equipamentos. 
A água pode ser contaminada nos processos industriais com produtos químicos, e seu descarte pode contaminar rios e aqüíferos subterrâneos com materiais tóxicos e substâncias que levam a uma alta demanda de oxigênio.

Além disso, a água da chuva proveniente das instalações pode também ser contaminada sendo necessário, em muitas unidades fabris, implantar um sistema de drenagem das áreas de armazenamento, produção e pátios para direcionar as águas pluviais a tanques de tratamento antes da descarga no solo ou rios.

As emissões gasosas incluem partículas, óxidos de enxôfre, carbono e nitrogênio procedentes das caldeiras. Incluem ainda amoníaco e outros compostos de nitrogênio e cloro provenientes de vários processos.

Os resíduos sólidos incluem restos de matérias-primas, lodos das caldeiras e da limpeza dos equipamentos.

Compressores, centrífugas, válvulas, tubulações, turbinas e resfriadores são fontes de poluição sonora que devem ser minimizadas com novos equipamentos, isolamento de áreas, e uso de equipamentos de proteção individual.

\subsubsection{A questão ambiental no Grupo Unilever}

O organograma da Unilever Brasil, em suas unidades, compreende um Diretor Técnico, Gerente de Fábrica e Gerências por áreas. À Gerência de Engenharia ligam-se a Coordenadoria de Novos Projetos e a Coordenadoria de Meio Ambiente.

A Divisão HPC - "Home and Personal Care" - que uniu as Divisões Elida Gibbs e Lever (atual Unilever Higiene e Beleza) - apresenta em seu organograma uma Gerência Nacional de Meio Ambiente para efetivar o benchmarking (difusão das melhores práticas) entre as unidades fabris, otimizar sinergias e compor estratégias.

Internacionalmente a Unilever tem um Grupo de Meio Ambiente estruturado para delinear diretrizes em questões ambientais. Compreende representantes dos diversos grupos de negócios e especialistas em segurança, saúde e meio ambiente. Este Grupo de Meio Ambiente desenvolve políticas e estratégias e faz recomendações à empresa tendo 
como foco principal a eco-eficiência nas operações de manufatura e nos produtos e as iniciativas de desenvolvimento sustentado na pesca, na agricultura e no uso da água.

A política ambiental da Unilever aponta como objetivos principais:

- implementar produtos, inclusive embalagens, e processos ambientalmente seguros;

- reduzir resíduos, conservar energia e explorar oportunidades para reutilização e reciclagem.

Para atingir estes objetivos a empresa procura:

- avaliar o impacto ambiental de todas as atividades, do desenvolvimento de produtos, ao uso e descarte, passando pela produção e distribuição;

- utilizar critérios ambientais mais restritivos do que os requeridos pela legislação quando assim for considerado apropriado pela empresa;

- utilizar padrões correntes na avaliação de impactos ambientais mas procurar desenvolver métodos superiores aos usuais;

- desenvolver sistemas de gestão ambiental como parte do dia-a-dia das operações, com relatórios e procedimentos de controle;

- encorajar fornecedores a adotar melhores procedimentos ambientais;

- colaborar com corporações, agências governamentais, parceiros e outras organizações para promover cuidados com o ambiente, aumentar 0 conhecimento ambiental e disseminar melhores práticas;

- estar alerta e responsivo para novos conhecimentos e para a opinião pública.

A Unilever ainda se propõe a ser comunicativa para:

- fornecer informações sobre o uso e descarte seguros de seus produtos;

- conscientizar e motivar seus funcionários sobre a política ambiental da empresa;

- publicar informações sobre seu desempenho ambiental introduzindo progressivamente um sistema mais abrangente de relatórios. 
Como estratégias, a Unilever proclama o uso de eco-eficiência mesmo na cadeia de fornecedores; a consideração de fatores ambientais no desenvolvimento de produtos (eco-inovação); e a busca por iniciativas de sustentabiliddade na pesca, agricultura e uso da água.

Para a conservação da pesca a empresa se compromete a, até 2005, comprar pescado somente de estoques sustentáveis encorajando para tanto seus fornecedores. Para a agricultura o grupo, reconhecendo que 2/3 de sua matéria-prima é produto agrícola, busca, com parceiros, desenvolver uma prática sustentável além de informar os consumidores sobre a origem dos produtos.

Quanto à água, a empresa reconhece este recurso como finito e sob intensa pressão; reconhece o uso da água limpa pelos consumidores de seus produtos, a necessidade da água na agricultura e nos processos fabris. Compromete-se a recuperar, proteger e preservar recursos hídricos.

Procurando atuar nos aspectos ambientais de suas atividades, a Unilever dispõe do Centro de Segurança e Proteção Ambiental, um centro próprio de pesquisa para análise de riscos de produtos, processos e localidades.

Realiza pesquisas em ciências ambientais, avalia ciclo de vida de produtos e orienta sistemas de gestão ambiental para os objetivos de ecoeficiência e eco-inovação e para iniciativas de sustentabilidade.

Visando independência das análises, seus pesquisadores não estão diretamente envolvidos com os produtos ou com a tecnologia utilizada.

O Grupo de Meio Ambiente é o setor da Unilever, em sua conjuntura internacional, encarregado de monitorar o desempenho ambiental da empresa e publicar relatórios bianuais, sendo acompanhado por auditores externos.

Para monitorar o desempenho da produção e direcionar melhorias, a Unilever utiliza 6 medidas de eco-eficiência:

1) Demanda Química de Oxigênio - DQO kg/ton

representa ingredientes e produtos perdidos na fabricação e nas operações de limpeza; é medida usada para controlar descargas industriais e para calcular níveis de tratamento de esgotos 
2) Resíduos perigosos - $\mathrm{kg} / \mathrm{ton}$

3) Resíduos não-perigosos - kg/ton

os dados da Unilever se baseiam na classificação de resíduos adotada em cada localidade

4) Água - $m^{3}$ /ton

inclui água como ingrediente nos produtos, utilidades, geração de vapor, higiene e limpeza gerando efluentes líquidos

5) Energia - GJ/ton (considerando energia elétrica, óleos combustíveis e gás)

deriva para cálculo de produção de $\mathrm{CO}^{2}$

6) Óxidos de Enxôfre - SO kg/ton

este parâmetro de emissão gasosa é relevante em quase todos os sítios pois quase todos utilizam caldeiras para produção de vapor; às vezes, óleo diesel é também utilizado na geração de eletricidade nas fábricas; os dados são calculados do consumo total de combustível e de seu conteúdo em óxidos de enxôfre que contribuem para a chuva ácida

Quanto aos relatórios ambientais, a versão de 2000 foi divulgada pela Internet (em 1996 e 1998 foram versões impressas). Recebeu auditoria externa da firma Aspinwall \& Company Limited, UK, com recomendações para revisão dos parâmetros de eco-eficiência, devendo vir a considerar outros indicadores do desempenho de processos de manufatura, e para adição de outros temas de sustentabilidade incluindo embalagens e disposição de resíduos.

As Tabelas 3 e 4, que seguem, trazem dados ambientais da empresa Unilever, considerada em seu total de unidades. 


\section{Tabela 3}

Desempenho ambiental por tonelada de produtos das linhas de produção do grupo Unilever (todas as unidades somadas) entre 1995 e 1999 e metas para 2000 e 2004

\begin{tabular}{|c|c|c|c|c|c|c|c|}
\hline $\begin{array}{l}\text { Custos } \\
\text { ambientais } \\
\text { (unidade/tonelada } \\
\text { de produtos) }\end{array}$ & 1995 & $\mid 1996$ & $\mid 1997$ & $\mid 1998$ & 1999 & $\begin{array}{l}\text { meta } \\
2000\end{array}$ & $\begin{array}{l}\text { meta } \\
2004\end{array}$ \\
\hline DQO kg/ton & 3,94 & 3,65 & 3,23 & 2,95 & 2,79 & 2,54 & 2,12 \\
\hline RT kg/ton & 0,69 & 0,96 & 0,98 & 0,66 & 0,62 & 0,57 & 0,44 \\
\hline RNT kg/ton & 23,68 & 17,58 & 17,46 & 14,86 & 13,12 & 11,75 & 10,28 \\
\hline ÁGUA m³/ton & 7,94 & 7,21 & 6,79 & 6,54 & 6,06 & 5,79 & 5,28 \\
\hline ENERGIA GJ/ton & 2,91 & 2,83 & 2,69 & 2,57 & 2,40 & & \\
\hline $\mathrm{CO}^{2} \mathrm{~kg} / \mathrm{ton}$ & 247,63 & 243,61 & 226,47 & 217,59 & 208,49 & 202,26 & 184,76 \\
\hline $\mathrm{SO}_{x} \mathrm{~kg} / \mathrm{ton}$ & 0,68 & 0,71 & 0,59 & 0,55 & 0,45 & 0,41 & 0,34 \\
\hline
\end{tabular}

(GJ $=10^{9}$ joule)

(Fonte: Relatório Ambiental 2000 da Unilever divulgado via Internet, www.unilever.com)

A Tabela acima indica redução de custos ambientais/tonelada de produtos, enquanto a Tabela 4 (página seguinte) indica redução de custos ambientais totais mesmo com o incremento da produção.

\section{Tabela 4}

Desempenho ambiental total e produção total da Unilever entre 1995 e 1999

\begin{tabular}{l|l|l|l|l|l} 
& 1995 & 1996 & 1997 & 1998 & 1999 \\
\hline DQO $10^{3}$ ton & 74,8 & 74,1 & 67,7 & 63,0 & 61,1 \\
\cline { 2 - 6 } $\begin{array}{l}\text { RT } 10^{3} \text { ton } \\
\text { RNT } 10^{3} \text { ton }\end{array}$ & 13,8 & 20,7 & 21,5 & 14,7 & 14,0 \\
\cline { 2 - 6 } $\begin{array}{l}\text { ÁGUA } 10^{6} \mathrm{~m}^{3} \\
\text { ENERGIA } 10^{6} \text { GJ J }\end{array}$ & 163,2 & 382,9 & 387,7 & 331,9 & 300,4 \\
\cline { 2 - 6 } $\mathrm{CO}^{2} 10^{6}$ ton & 59,7 & 63,0 & 60,6 & 57,6 & 54,9 \\
\cline { 2 - 6 } $\begin{array}{l}\mathrm{SO}_{\times} 10^{3} \text { ton } \\
\text { produção } 10^{3} \text { ton }\end{array}$ & 13,1 & 5,4 & 5,1 & 4,9 & 4,8 \\
\cline { 2 - 6 } & $20.601,3$ & 14,3 & 12,5 & 12,1 & 10,3 \\
\hline
\end{tabular}

(Fonte: Relatório Ambiental 2000 da Unilever divulgado via Internet, www.unilever.com) 


\subsubsection{A fábrica de Vinhedo e o meio ambiente}

Para facilitar a monitoração e a divulgação de dados a Unilever incentiva que cada unidade tenha seu sistema de gestão ambiental certificado pela norma ISO 14001.

A fábrica Unilever de Vinhedo obteve esta certificação em 1999 e teve como motivações em relação ao meio ambiente o comprometimento corporativo e, em nível local, da unidade, a economia de recursos e o marketing institucional.

Como principais aspectos ambientais esta unidade considera a geração de resíduos sólidos e de efluentes líquidos.

Para diminuir a quantidade de resíduos sólidos, a empresa vem diminuindo e promovendo a reciclagem de embalagens de matéria-prima. Isto causa a diminuição de disposição para aterros com economia na coleta e a contribuição social através da venda dos materiais recicláveis.

Os efluentes industriais desta fábrica recebem tratamento físico, químico e biológico antes do despejo no rio Capivari. Além disso, o lodo gerado na sua Estação de Tratamento de Esgoto vem sendo destinado para compostagem orgânica, possibilitando assim a formação de um ciclo de reaproveitamento de significativa fonte de geração de resíduo.

A Elida Gibbs (fábrica de Vinhedo) vem, ainda, se preocupando com a geração de resíduos pós-consumo. Realiza pesquisas para desenvolvimento de novas embalagens e campanhas de coleta seletiva para permitir reciclagem desses materiais.

A definição de objetivos do seu sistema de gestão ambiental atende a legislação local e os parâmetros corporativos da Unilever buscando uma Produção Limpa, seguindo a norma mais restritiva.

Uma consultoria externa participou do processo de implantação do sistema de gestão ambiental da fábrica de Vinhedo, sistema este baseado na norma ISO14001. Esta consultoria externa participa continuamente no treinamento de funcionários para gestão ambiental.

Para implantação do sistema de gestão ambiental nesta fábrica houve treinamento de auditores internos, treinamento de todos os funcionários sobre a política ambiental, treinamento nos locais de trabalho (on the job), incentivo para especialização do coordenador de meio 
ambiente da fábrica em gestão ambiental e auditoria de sistemas e curso sobre impactos ambientais para as áreas de engenharia, produção e apoio.

Para continuidade do enfoque ambiental na produção são realizados mensalmente os chamados "diálogos de segurança e meio ambiente", com duração de 30 minutos. Também é realizada anualmente a Semana de Meio Ambiente para conscientização e informação de todos os funcionários.

Outros programas de treinamento - em saúde, segurança e em TPM Total Perfeição da Manufatura - também revertem para as questões ambientais da unidade por melhorar o uso de materiais e equipamentos, diminuir desperdício de materiais e de geração de resíduos.

A empresa verifica reação positiva e participativa dos funcionários em geral para a implantação e funcionamento do sistema de gestão ambiental cujas premissas, juntamente com as voltadas para saúde e segurança dos trabalhadores, podem inviabilizar projetos tecnológicos, de equipamentos, produtos e embalagens.

No meio empresarial, em 1998 a Elida Gibbs de Vinhedo recebeu menção honrosa da Federação das Indústrias do Estado de São Paulo FIESP e da Confederação Nacional da Indústria - CNI, pelo seu sistema de redução e tratamento de efluentes.

Os resultados ambientais desta fábrica, em 2000, foram:

- geração de resíduo sólido reciclável ou não por tonelada produzida $36,9 \mathrm{~kg} /$ ton (< que a meta de $38 \mathrm{~kg} /$ ton e significando redução de $19 \%$ em relação aos dados de 1999);

- efluentes industriais por tonelada produzida -

$0,110 \mathrm{~m}^{3} /$ ton (< que a meta de $0,115 \mathrm{~m}^{3} /$ ton e significando redução de $5 \%$ em relação aos dados de 1999);

- consumo de água por tonelada produzida -

$1,31 \mathrm{~m}^{3} /$ ton (< que a meta de $1,6 \mathrm{~m}^{3} /$ ton e significando redução de $18 \%$ em relação aos dados de 1999) 
A coleta seletiva incentivada pela fábrica de Vinhedo resultou, durante $o$ ano de 2000, em:

- $73.466 \mathrm{~kg}$ de resíduos recicláveis recolhidos em supermercados;

- $5.413,65 \mathrm{~kg}$ de resíduos recicláveis recolhidos por funcionários em suas residências;

- $4.951 \mathrm{~kg}$ de resíduos recicláveis recolhidos em escolas, totalizando $83.830,65 \mathrm{~kg}$ de materiais recicláveis não dispostos em aterros sanitários.

\subsubsection{O modelo empresarial de meio ambiente}

No geral, a preocupação com a sustentabilidade nas empresas ainda é pontual, localizada em seu interior e não uniformemente difundida.

Texto de Ulhoi (1996: 14), nesta abordagem, orienta que o desenvolvimento sustentável corporativo requer redefinição de valores e de visão corporativa.

Requer integração da temática ambiental em todas as funções gerenciais para que se alcance um balanço sustentável entre a performance econômica e ecológica da empresa.

Isto significa que departamentos de compras terão que encontrar novas, sustentáveis, fontes de suplementos, reduzir embalagens e utilizar mais materiais recicláveis.

Departamentos de pesquisa e desenvolvimento de produtos podem contribuir fornecendo dados comparativos sobre impactos ambientais, identificando processos que usam recursos mais eficientemente, encontrando novos usos para resíduos, e contribuindo para a criação de produtos mais duráveis.

E departamentos de produção podem utilizar novos processos que consomem menos energia e materiais.

É certo que nas corporações ocorrem intenções altamente positivas com as questões ambientais mas também conflitos entre estas intenções ambientais e considerações econômicas, especialmente na separação de custos ambientais de outros custos e na visão global de longo prazo. 
Mas dada a importância do envolvimento das empresas e corporações na melhoria ambiental, trazemos uma tabela (Tabela 5) deste mesmo autor, Ulhoi (1996), confrontando os estágios evolutivos de gestão ambiental corporativa com critérios de proteção ambiental, envolvimento organizacional e programa de gestão.

TABELA 5 - Estágios evolutivos de gestão ambiental corporativa

\begin{tabular}{|c|c|c|c|c|c|c|}
\hline critérios & estágio 1 & estágio 2 & estágio 3 & | estágio 4 & estágio 5 & estágio 6 \\
\hline $\begin{array}{l}\text { proteção } \\
\text { ambiental }\end{array}$ & nenhuma & mínima & moderada & compreensiva & máxima & $\begin{array}{l}\text { prevenção } \\
\text { máxima }\end{array}$ \\
\hline $\begin{array}{l}\text { mentalidade } \\
\text { gerencial }\end{array}$ & $\begin{array}{l}\text { gestão } \\
\text { ambiental } \\
\text { não é } \\
\text { necessária }\end{array}$ & $\begin{array}{l}\text { objetivos } \\
\text { ambientais } \\
\text { devem existir } \\
\text { quando } \\
\text { necessário }\end{array}$ & $\begin{array}{l}\text { gestão } \\
\text { ambiental é } \\
\text { uma função } \\
\text { necessária }\end{array}$ & $\begin{array}{l}\text { gestão } \\
\text { ambiental é } \\
\text { uma } \\
\text { importante } \\
\text { função dos } \\
\text { negócios }\end{array}$ & $\begin{array}{l}\text { gestão } \\
\text { ambiental é } \\
\text { priorizada }\end{array}$ & $\begin{array}{l}\text { gestão } \\
\text { ambiental } \\
\text { totalmente } \\
\text { integrada }\end{array}$ \\
\hline recursos & mínimos & $\begin{array}{l}\text { para } \\
\text { problemas }\end{array}$ & consistentes & $\begin{array}{l}\text { geralmente } \\
\text { suficientes }\end{array}$ & abertos & prioridade \\
\hline objetivos & nenhum & $\begin{array}{l}\text { resolução de } \\
\text { problemas }\end{array}$ & $\begin{array}{l}\text { satisfazer } \\
\text { responsabi// } \\
\text { corporativa }\end{array}$ & $\begin{array}{l}\text { minimizar } \\
\text { impactos } \\
\text { negativos }\end{array}$ & gestão ativa & prevenção \\
\hline medição & nenhuma & nenhuma & qualitativa & quantitativa & $\begin{array}{l}\text { quantitativa e } \\
\text { qualitativa }\end{array}$ & $\begin{array}{l}\text { indicadores } \\
\text { de } \\
\text { sustentabili// }\end{array}$ \\
\hline integração & nenhuma & às vezes & mínima & moderada & ativa & total \\
\hline comunicação & nenhuma & exceções & interna & $\begin{array}{l}\text { interna, } \\
\text { alguma } \\
\text { externa }\end{array}$ & $\begin{array}{l}\text { interna e } \\
\text { externa }\end{array}$ & pública \\
\hline $\begin{array}{l}\text { horizonte } \\
\text { temporal }\end{array}$ & curto & curto & curto & curto-médio & médio & longo \\
\hline
\end{tabular}

(preparada a partir de tabela original em Ulhoi (1996: 132))

Podemos situar a Unilever, como Grupo e a fábrica de Vinhedo, entre os estágios 3 e 4 . Não optamos pelo estágio 4 pelos termos do critério 'mentalidade gerencial'. Vimos a gestão ambiental ser considerada importante mas não pudemos nos assegurar desta importância 'como função dos negócios'. 
Quanto à fábrica de Vinhedo, não considerando aqui seus fornecedores de matérias-primas (produtos químicos) cujos riscos ambientais foram brevemente abordados, a empresa, em seu processo produtivo, atende a legislação ambiental e de saúde ocupacional vigentes e as orientações da matriz do grupo.

As orientações da Unilever apontam ações para sustentabilidade e incentivam a certificação das gestões ambientais pelas normas ISO 14001.

As ações apontadas pela matriz da empresa conduzem à diminuição do uso de recursos naturais e à reciclagem. Assim, consideramos que o modelo empresarial de meio ambiente que encontramos na empresa Unilever - Divisão Elida Gibbs, em Vinhedo, se enquadra como uma representação técnico-material preocupada com a eficiência eco-energética.

Consideramos ainda que o incentivo àquela certificação, além de promover vantagens competitivas, dissemina e padroniza justamente tais ações formando pensamentos hegemônicos.

Acselrad (2001: 40) nos alerta que, nesta concepção técnico-material de sustentabilidade, que ruma para eficiência eco-energética, "a recusa do antagonismo entre o meio ambiente e a economia fará também da busca da sustentabilidade urbana a ocasião de fazer valer a potência simbólica do mercado como instância de regulação das cidades" fazendo-as produtivas e competitivas em termos econômicos. 


\subsection{Resultados das entrevistas com funcionários da Divisão Elida}

\section{Gibbs - Unilever - em Vinhedo, São Paulo}

O tamanho da população (funcionários das linhas de produção da Divisão Elida Gibbs da Unilever em Vinhedo, SP) considerada neste trabalho foi de 600 pessoas, e a variação de respostas ao questionário aplicado em 25 entrevistas preliminares foi pequena. Assim, uma avaliação estatística (Bunchaft, 2000; Pereira, 2001) apontou para a adequação de uma amostra de 64 pessoas.

Simplificadamente, neste estudo o objeto é 0 homem e as manifestações de seus atributos (verificadas como declarações sobre questões ligadas a conhecimento ambiental) variam entre os elementos em qualidade e não em quantidade. Outros atributos (como idade, tempo de residência e de ocupação) variam em quantidade.

As variáveis dependente (conhecimento ambiental ou, melhor, amplitude da percepção ambiental) e independente (treinamento recebido em gestão ambiental ou aporte de conhecimento ambiental na empresa) são qualitativas, primariamente nominais. As variáveis de controle são variáveis discretas (idade, tempo de moradia em Vinhedo, tempo de trabalho na empresa Unilever).

Os dados foram agrupados em categorias (dados categorizados) e apresentados para análise descritiva em tabela e gráficos de distribuição de freqüências de categorias.

A amostra foi estratificada por gênero para manter a proporcionalidade em relação ao grupo objetivado.

Os respondentes foram escolhidos ao acaso em sua circulação obrigatória e aleatória entre os vestiários e a área de produção, em espaço que compreende refeitório e área de descanso e convivência.

Em duas intervenções (visitas), foram definidos 4 períodos de amostragem compreendendo a escolha aleatória, por passagem em determinado ponto próximo aos vestiários, de 16 pessoas em cada período, resultando para a análise respostas de 16 mulheres e 48 homens. 
As entrevistas foram concebidas para verificar percepção ou cognição ambiental em relação ao município de Vinhedo, substituindo-se na amostra os respondentes que se referiram a outro município (foi citado Valinhos como moradia por 3 respondentes, substituídos na amostra).

Foram questões nas entrevistas, além de idade, tempo de residência em Vinhedo e tempo de trabalho na empresa Elida Gibbs: o bairro de residência em Vinhedo, aspectos ambientais notados em Vinhedo, atitudes pessoais em relação ao meio ambiente, foco do treinamento recebido no sistema de gestão ambiental da empresa e mudanças no trabalho com a implantação de tal sistema.

São apresentados a seguir, em tabela (Tabela 6) e gráficos (Gráfico 1, 2 e 3), as características da amostra: gênero, idade, tempo de residência em Vinhedo e tempo de trabalho na empresa Elida Gibbs - Unilever.

Tabela 6 - Características (idade e gênero) da amostra de funcionários da empresa Elida Gibbs - Unilever, Vinhedo, SP, 2001 ( $n=64$ )

\begin{tabular}{l|lll} 
idade/sexo & homem & mulher & total \\
\hline 20-29 anos & 25 & 6 & 31 \\
30-39 anos & 22 & 8 & 30 \\
40-49 anos & 1 & 2 & 3 \\
total & 48 & 16 & 64
\end{tabular}


Gráfico 1 - Tempo de residência em Vinhedo da amostra de funcionários $(n=64)$ da empresa Elida Gibbs - Unilever, Vinhedo, SP, 2001, por gênero

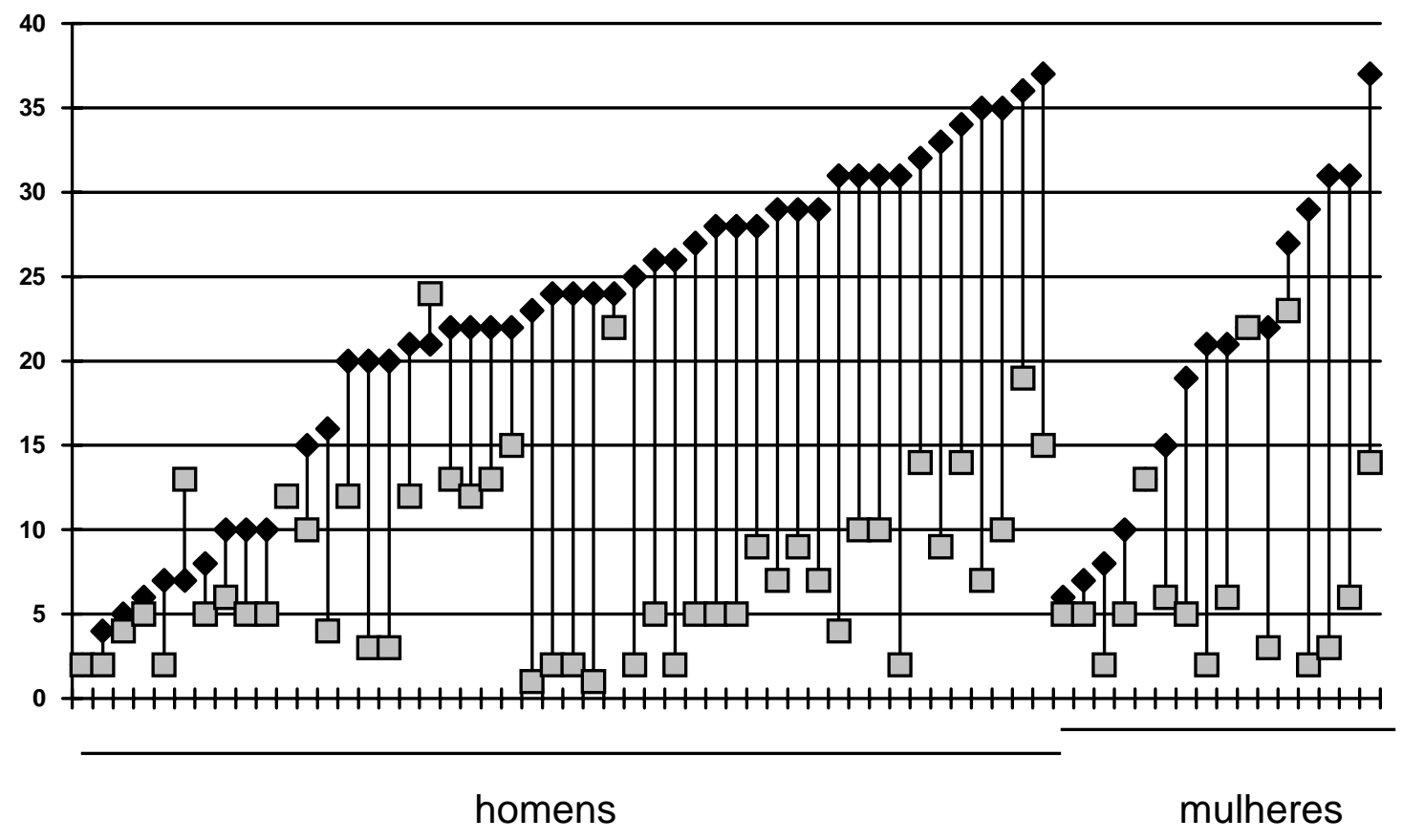

\section{Legenda}

$\checkmark \quad$ tempo de residência em Vinhedo, SP

tempo de trabalho na empresa Elida Gibbs

Apresentação por ordem crescente de tempo de residência em Vinhedo cotejado com tempo de trabalho de cada funcionário na empresa Elida Gibbs; ordenação dos indivíduos ( $\mathrm{n}=64)$ por gênero

Tempo médio de residência em Vinhedo:

homens $\quad-22,13$ anos

mulheres $\quad-19,94$ anos 
Gráfico 2 - Tempo de trabalho na empresa da amostra de funcionários $(n=64)$ da empresa Elida Gibbs - Unilever, Vinhedo, SP, 2001, por gênero

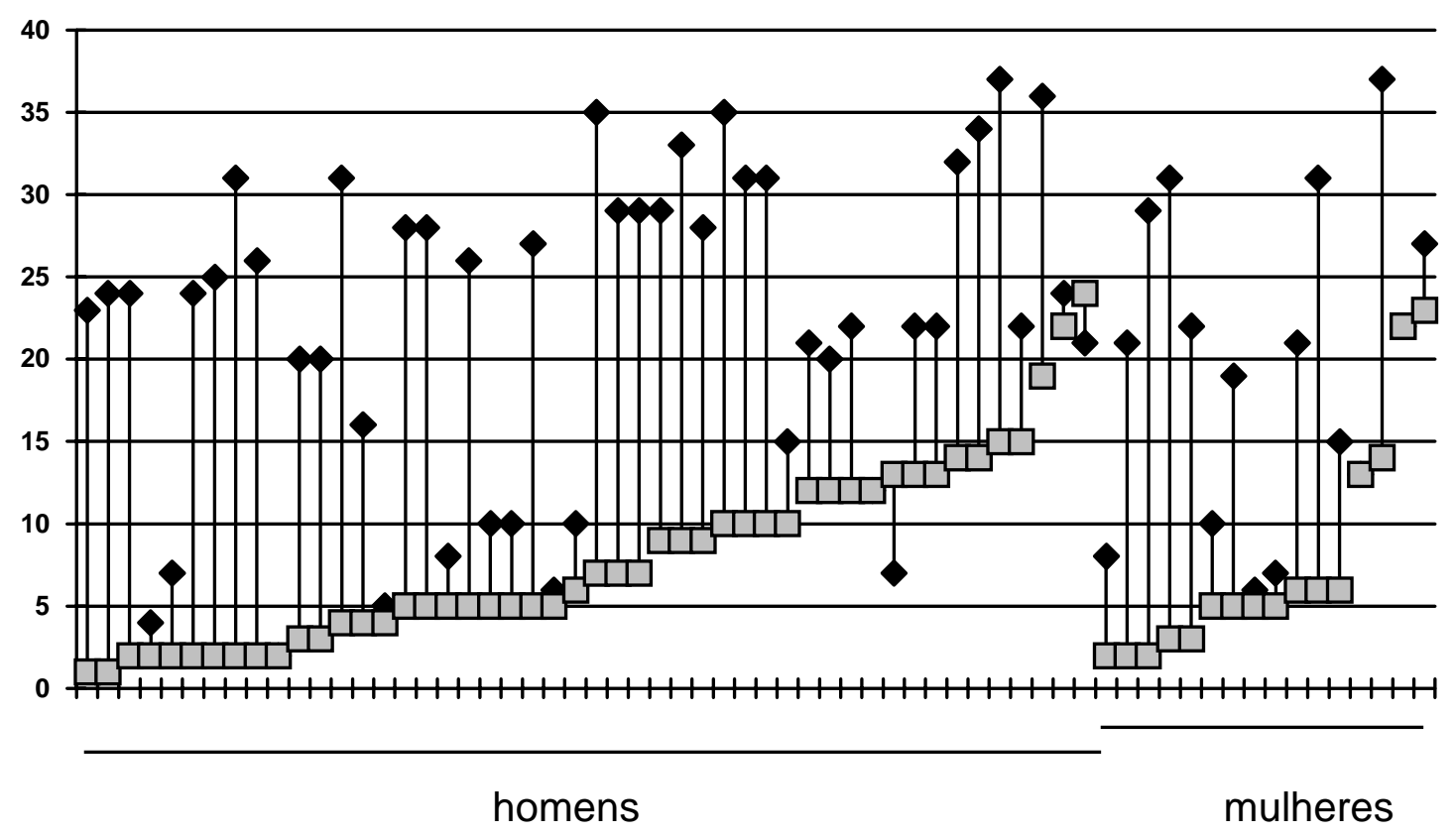

\section{Legenda}

$\checkmark \quad$ tempo de residência em Vinhedo, SP

tempo de trabalho na empresa Elida Gibbs

Apresentação por ordem crescente de tempo de trabalho na empresa cotejado com tempo de residência de cada indivíduo em Vinhedo; ordenação dos indivíduos ( $\mathrm{n}=64)$ por gênero

Tempo médio de trabalho na empresa Elida Gibbs:

homens - 7,92 anos

mulheres $\quad-7,63$ anos 
Gráfico 3 - Tempo de trabalho na empresa e tempo de residência em Vinhedo da amostra de funcionários $(n=64)$ da empresa Elida Gibbs Unilever, Vinhedo, SP, 2001, grupo total

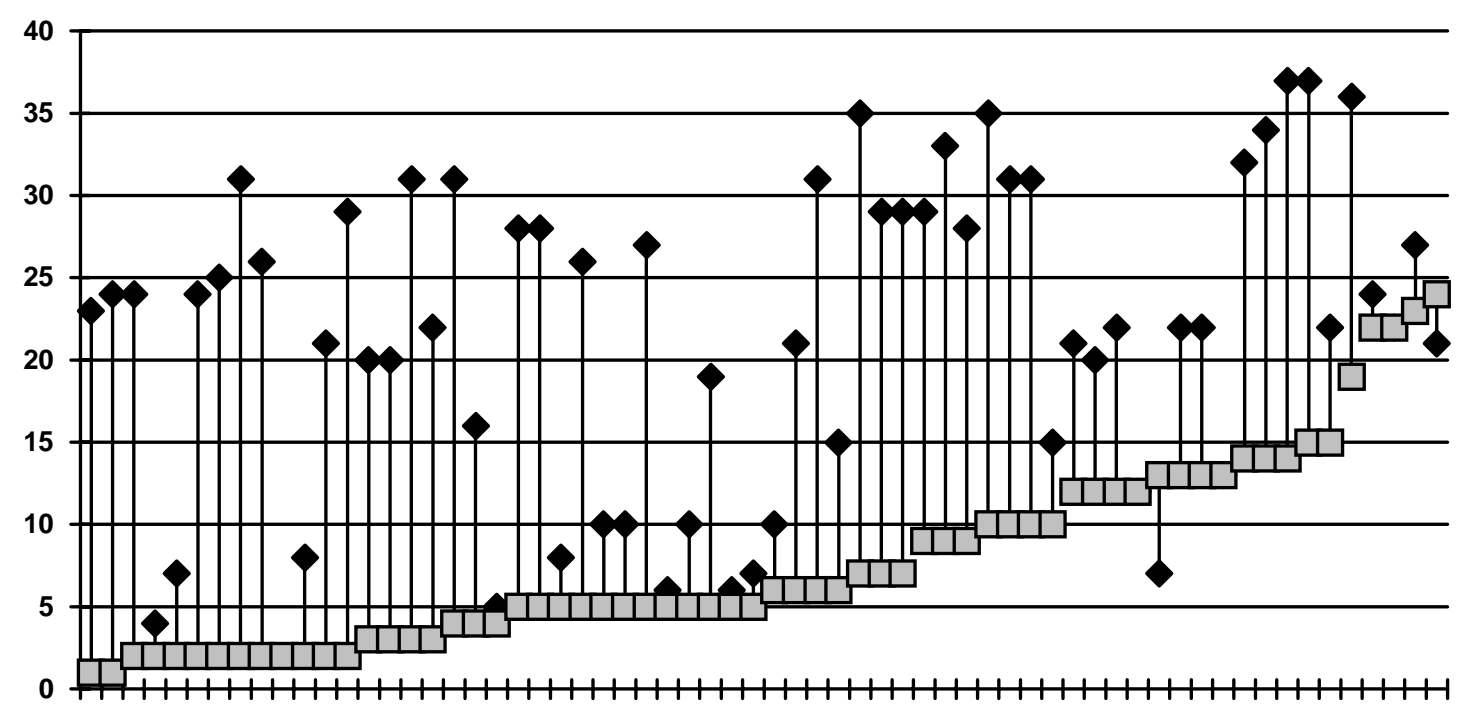

\section{Legenda}

$\checkmark \quad$ tempo de residência em Vinhedo, SP

tempo de trabalho na empresa Elida Gibbs

Apresentação por ordem crescente de tempo de trabalho na empresa cotejado com tempo de residência de cada funcionário em Vinhedo; grupo total ( $n=64)$, sem separação por gênero

Grupo total:

tempo médio de residência em Vinhedo

21,58 anos

tempo médio de trabalho na empresa Elida Gibbs $\quad 7,84$ anos

Em suas características gerais, a amostra foi constituída por adultos jovens, entre 20 e 40 anos em sua grande maioria, com $85 \%$ residentes em Vinhedo há 10 anos ou mais, e com $68 \%$ destes funcionários trabalhando há pelo menos 5 anos na empresa Elida Gibbs - Unilever. 
Quanto aos aspectos ambientais notados em Vinhedo, as entrevistas se referiram ao que chama a atenção no ambiente da cidade, avaliada positiva ou negativamente. As repostas foram livres e resultaram em uma lista de citações de problemas ambientais transformados em categorias. Apesar das respostas livres, nenhum respondente se enquadrou em duas ou mais categorias.

Assim, para esta variável, foi construído gráfico (Gráfico 4) de distribuição de freqüências das categorias citadas.

Gráfico 4 - Freqüências das questões ambientais apontadas em Vinhedo pela amostra de funcionários $(n=64)$ da empresa Elida Gibbs - Unilever, Vinhedo, SP, 2001; estratificação por gênero (48 homens e 16 mulheres)

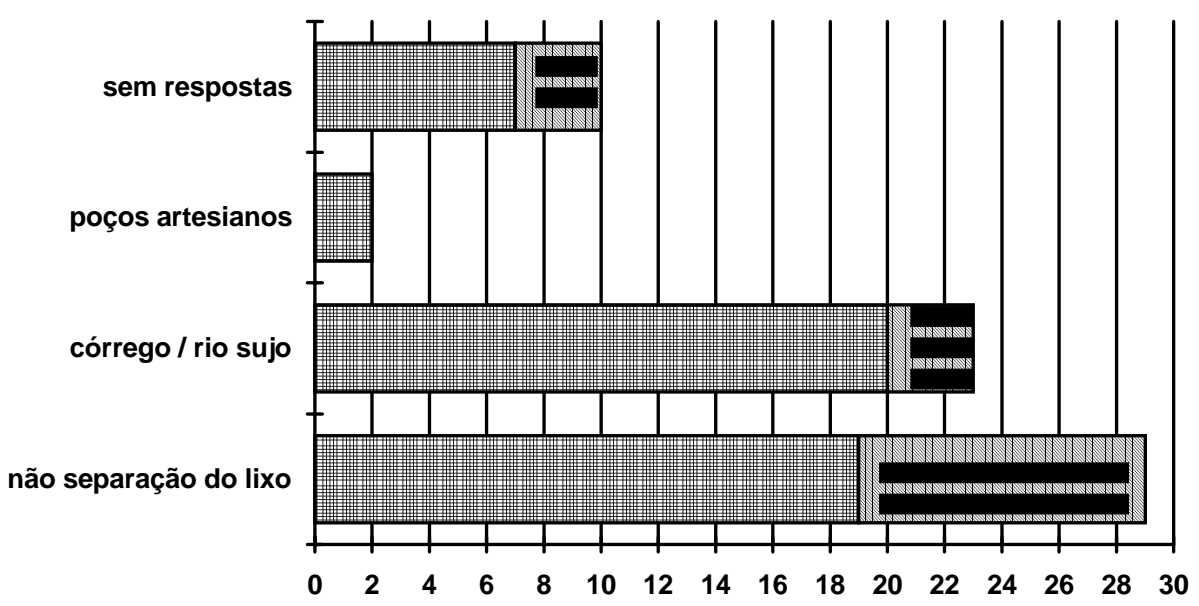

\section{Legenda}

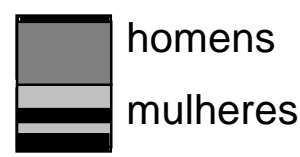

O cenário investigado mostrou-se bastante homogêneo. Analisado com estratificação por gênero, não mostrou respostas significativamente diferentes para os subgrupos.

Outra correlação analisada foi entre as questões ambientais apontadas e os bairros de moradia. A Figura 10, a seguir, indica os bairros de moradia dos funcionários da amostra, além de outros elementos do município de Vinhedo julgados de interesse para sua compreensão. 


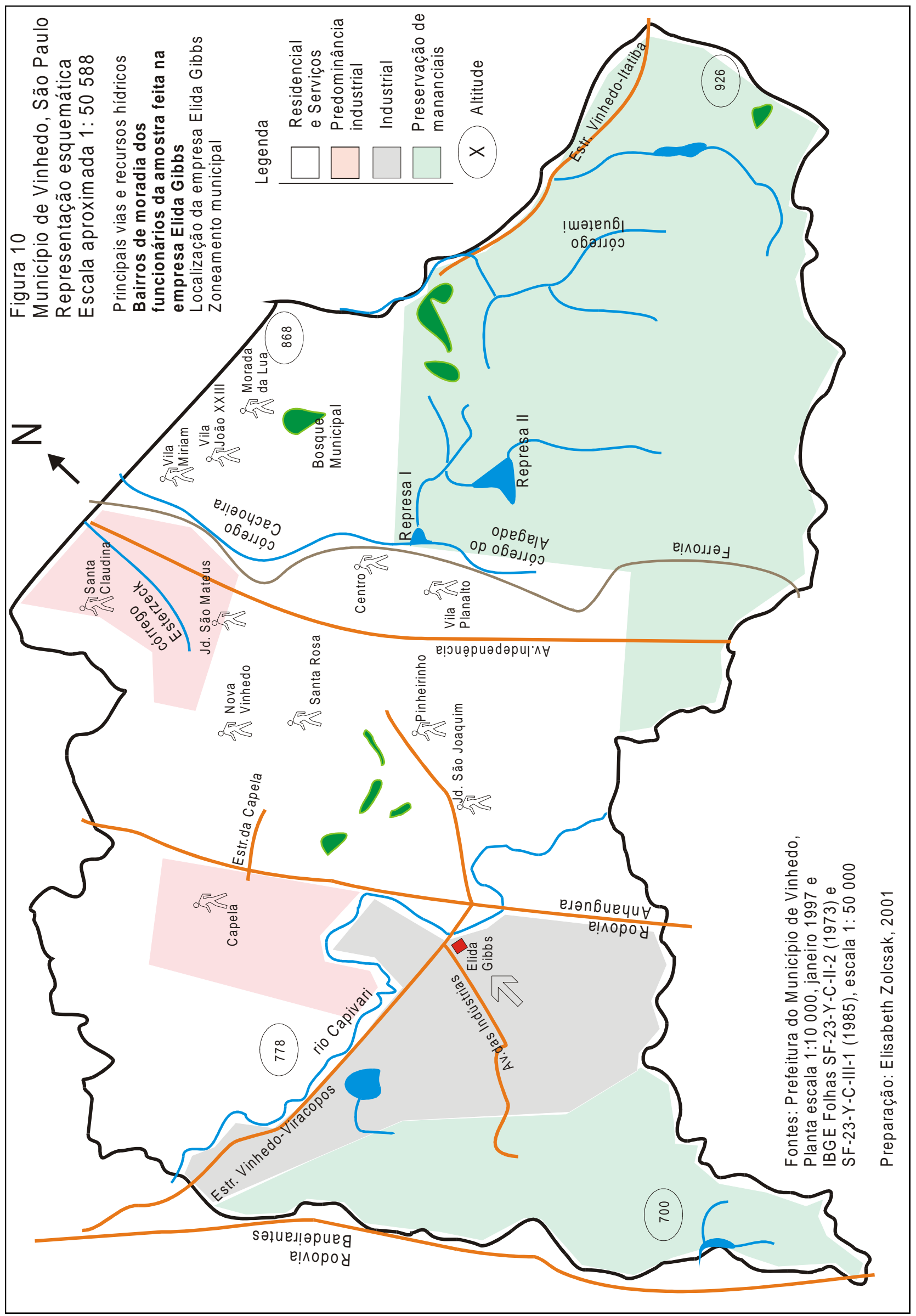


Os Gráficos 5 e 6, a seguir, ilustram as questões ambientais apontadas em Vinhedo pela amostra de funcionários da Elida Gibbs Unilever, distribuídas pelos bairros de moradia daqueles funcionários.

Gráfico 5 - Freqüências das questões ambientais apontadas em Vinhedo pela amostra de funcionários ( $n=64)$ da empresa Elida Gibbs - Unilever, Vinhedo, SP, 2001; distribuição das categorias por bairros de moradia

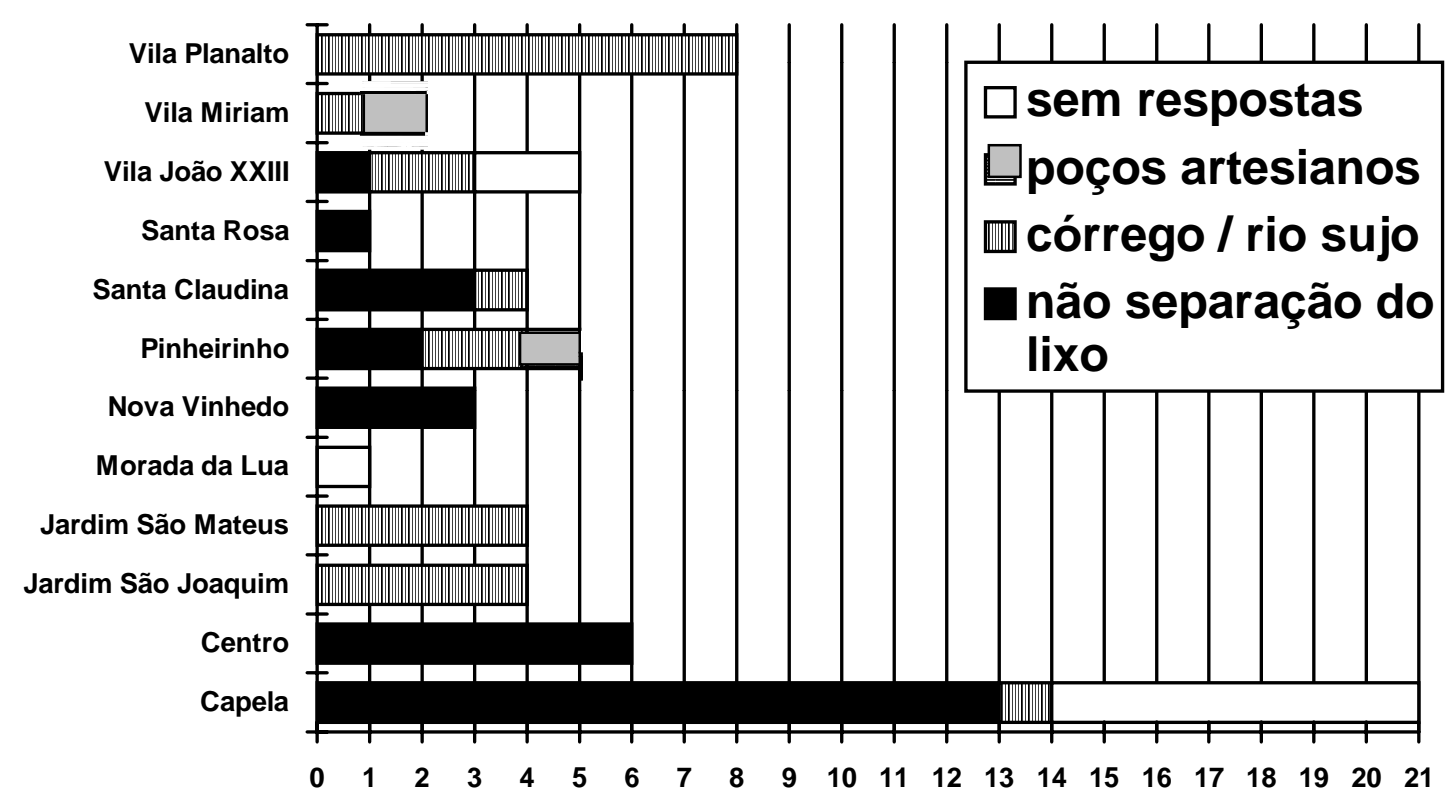


Gráfico 6 - Freqüências das questões ambientais apontadas em Vinhedo pela amostra de funcionários ( $n=64)$ da empresa Elida Gibbs - Unilever, Vinhedo, SP, 2001; distribuição das categorias por bairros de moradia e por gênero
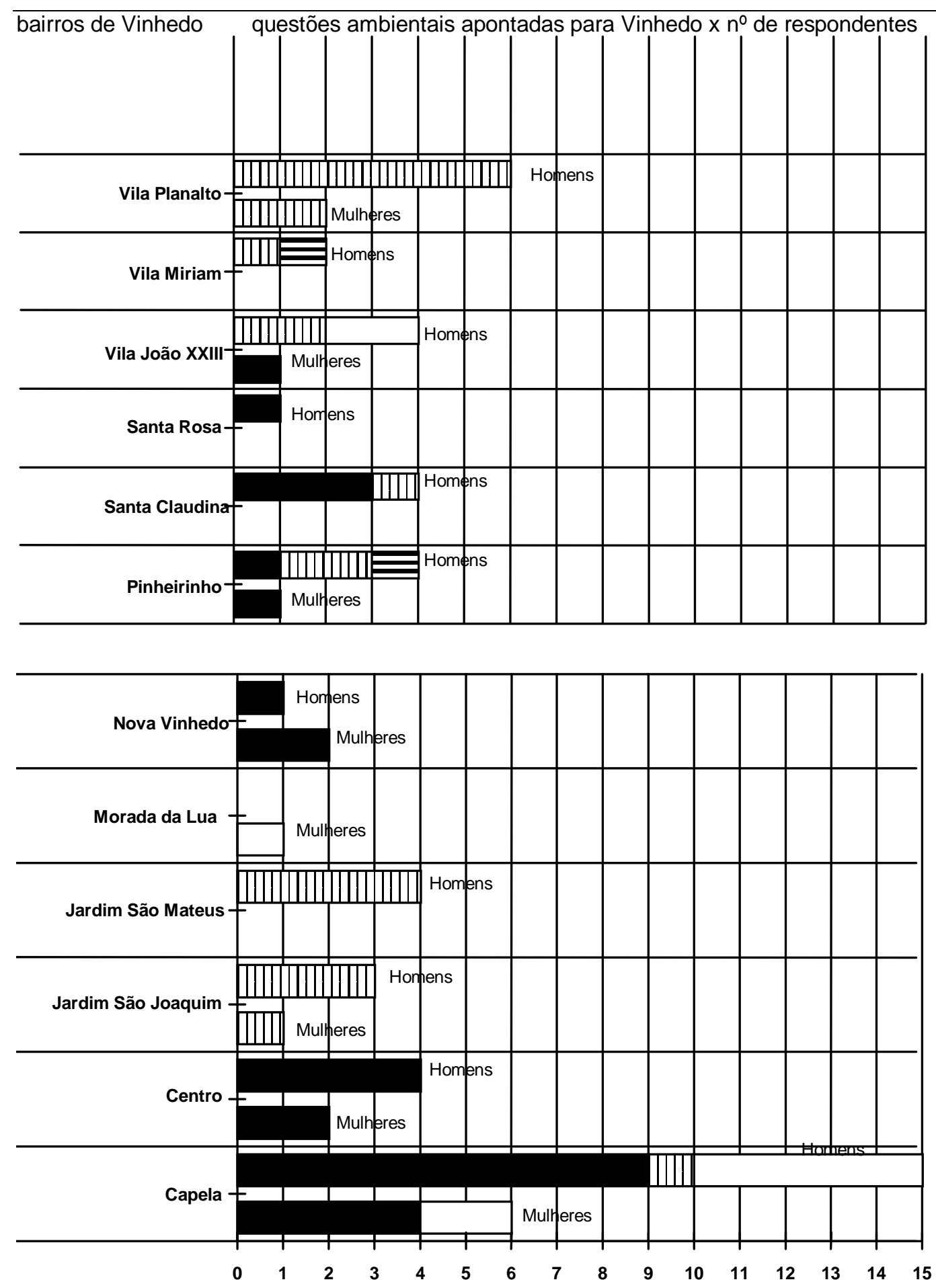

\section{Legenda}
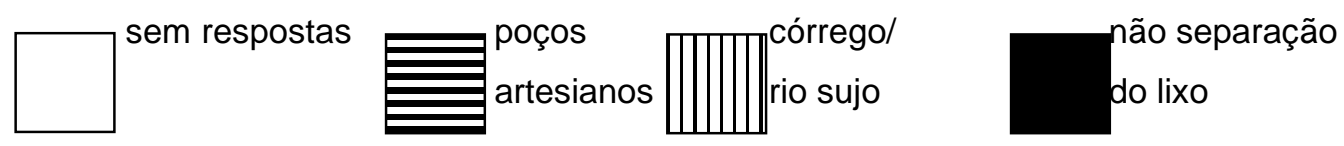
Inferimos uma correlação entre a questão ambiental apontada para Vinhedo e o bairro de moradia dos sujeitos da amostra, mais flagrante na categoria "córrego ou rio sujo" para os bairros Vila Planalto, Jardim São Mateus e Jardim São Joaquim, porém a amplitude da percepção ou cognição ambiental permaneceu homogênea e restrita.

$\mathrm{Na}$ questão sobre atitudes pessoais, $78 \%$ dos respondentes se referiram à separação de lixo para coleta seletiva. Outros não responderam.

Quanto ao foco do treinamento recebido no sistema de gestão ambiental da empresa, 95\% dos respondentes citaram a reciclagem de resíduos sólidos. Apenas 3 funcionários citaram o tratamento de efluentes.

Questionados sobre modificação no trabalho em função do sistema de gestão ambiental implantado, $90 \%$ dos funcionários da amostra se referiram à limpeza e organização do ambiente de trabalho.

Informação sobre a escolaridade dos funcionários da amostra foi obtida indiretamente, da empresa, e não durante as entrevistas, visando um diálogo informal, sem características de verificação de conhecimento escolar, com os respondentes.

A empresa informou que mais de $95 \%$ destes funcionários tem o ensino médio completo e que muitos o concluíram através do "Programa Educare", sediado no Centro de Vinhedo mas organizado e mantido pela fábrica.

\subsubsection{O modelo de meio ambiente do senso comum}

Inferimos das entrevistas que o modelo mental de meio ambiente que denominamos modelo do senso comum é o ambiente com minimização e reciclagem de resíduos e com ocultamento de córregos e rios poluídos, que nos coloca uma série de preocupações discutidas adiante neste texto.

Novamente citamos Acselrad (2001: 40) quando opina que a concepção de sustentabilidade como trajetória para eco-eficiência "é normalmente acompanhada da constituição de uma base social de apoio a projetos de mudança técnica urbana, pela via da educação ambiental, da disseminação de uma consciência ecológica, de projetos comunitários de reciclagem ou pelo engendramento de uma economia da reciclagem". 
Encontramos esta disseminação de consciência ecológica e projetos de reciclagem de resíduos em ações da Prefeitura Municipal de Vinhedo e nas atividades de educação ambiental da empresa Elida Gibbs para seus funcionários.

Verificamos um relato de uma equipe da Faculdade de Saúde Pública da USP que em 1996 desenvolveu um projeto-piloto de Educação Ambiental nas Usinas Pedreira e Piratininga da Eletropaulo, em São Paulo, SP. As autoras (Gunther et al., 1997) consideram as experiências de educação ambiental em empresas como um importante espaço institucional para introduzir conceitos e práticas sobre a preservação e recuperação do meio.

Mas também aquele projeto foi concebido a partir da minimização de resíduos na empresa e foi aplicado "com a finalidade de desenvolver uma nova mentalidade ambiental entre os funcionários, motivando-os a modificar os hábitos, posturas e práticas que prejudiquem o meio ambiente" (id. ib.: 310).

Sem dúvida que é importante a diminuição de consumo e de produção de rejeitos, como também é importante a promoção de insights individuais para novas atitudes em relação ao ambiente, mas reconhecemos simbólica esta ação de reciclagem por parte da comunidade quando isolada de outras avaliações e preocupações com o entorno.

Para a população de modo geral a concepção de sustentabilidade como equidade teria mais pertencimento. Para grupos sem a força econômica na política, a representação do ambiente como produto social, como cenário cultural e econômico, indica a percepção de desigualdades no acesso aos serviços públicos e de riscos ambientais trazidos quer pelas atividades econômicas como pelo meio físico indevidamente ocupado.

Se o modelo de meio ambiente do senso comum é o ambiente com minimização e reciclagem de resíduos e com ocultamento de córregos e rios poluídos, que inferimos, sua objetivação e poder de persuasão das políticas urbanas se simplifica em coletas seletivas e canalizações, estas sem dúvida inadequadas para o favorecimento ambiental, em termos de microclima e aspectos contemplativos e estéticos. 
Aspectos importantes do ambiente urbano, como habitações adequadas, fluxos, saneamento, proteção contra poluição pontual e difusa, passam a outros foros fragmentados das administrações públicas.

Um relatório do Ministério do Meio Ambiente (MMA, 1998) sobre pesquisa de opinião pública realizada em 1997 abordou os seguintes temas vinculados ao meio ambiente: valores da sociedade, capacidade de identificação e priorização de problemas, avaliação de instituições e grupos e disposição para participar e apoiar políticas públicas para o setor.

Uma das principais conclusões foi que há uma significativa consciência ambiental no Brasil, embora o brasileiro se considere pouco informado sobre as questões ambientais e com baixa capacidade de identificação de problemas. Essa "consciência" se revela em três componentes: a) a sacralização da natureza; b) a concepção naturalista do meio ambiente; c) uma disposição em não aceitar a poluição e a degradação ambiental.

Mais da metade da população brasileira, apontou o mesmo Relatório, acredita que a natureza é sagrada e não deve sofrer interferência do homem. A população residente na Região Norte é a que menos compartilhou desta visão (52\%), além de ser a que mais se identificou com a idéia de que a natureza não é sagrada e de que o homem pode usá-la de acordo com suas necessidades (21\%).

Quando perguntados sobre os três problemas ecológicos mais graves do Brasil, $45 \%$ dos entrevistados mencionaram espontaneamente a derrubada de árvores, queimadas ou a ocupação de florestas.

De acordo com aquele Relatório (MMA, 1998), o meio ambiente não apareceu entre as principais preocupações dos brasileiros - desemprego, saúde, educação, segurança e moradia foram as prioridades mais citadas mas ocupa o $7^{\circ}$ lugar nas preocupações de pessoas com renda mais alta e mais escolarizados. Entre as pessoas de menor escolaridade e menor renda, esta preocupação caiu para $11^{\circ}$ lugar. 
Tal Relatório nos indicou que o meio ambiente é visto como o ambiente natural e não o ambiente urbano que inclui as relações sociais, estas sim citadas como preocupações prioritárias.

A avaliação domiciliar dos agravos ambientais na cidade de São Paulo, realizada por Pedro Jacobi (1995), indicou como aspectos que despertam maiores preocupações dos moradores: a poluição do ar, a degradação e poluição das fontes hídricas e a interferência do despejo inadequado de resíduos sólidos.

Mas Jacobi conjeturou ser essa consciência advinda de uma variável cultural mais do que da realidade vivenciada. Todo mundo fala destes problemas ambientais mas nem todos as vivenciam e Jacobi conclui o trabalho preocupado com a assimilação do impacto da poluição do ambiente por todas as camadas da população que ainda enfatizam o papel governamental como controlador, gestor e direcionador da degradação ambiental.

Além disso, o autor citado notou um perfil dualizado de percepções na cidade reforçando a ênfase nos aspectos diretamente relacionados ao cotidiano domiciliar. Apontou os estratos que vivem em áreas plenamente urbanizadas e que têm acesso a todos os serviços e infra-estrutura urbana, e os estratos que residem em áreas periféricas.

Os primeiros enfatizam suas demandas principalmente para os componentes qualitativos de qualidade de vida; enquanto que os segundos requerem melhorias nas condições de acesso aos serviços urbanos básicos, como serviços de água e coleta de resíduos sólidos.

Encontramos assim que a percepção ambiental do cidadão comum em seu cotidiano é pouco rica. E preocupa que as atividades de conscientização ecológica, de educação ambiental, sejam tecnicistas mesmo que bem intencionadas e voltadas para o desenvolvimento de novas atitudes.

Preocupa que a sensação de informação dada pelas instituições reconhecidas, Estado e empresa, reforcem a alienação ambiental dos sujeitos. Alienação esta que os coloca à parte dos processos de construção social do espaço. 


\section{RETOMADA DO DIÁLOGO ENTRE OS MODELOS DE MEIO AMBIENTE}

Encontramos para Vinhedo, através de suas instituições públicas, uma representação técnico-material do ambiente. Da empresa Elida Gibbs Unilever - sediada neste município inferimos uma representação ambiental também técnico-material com concepção de sustentabilidade voltada para eco-eficiência ou eficiência eco-energética.

E encontramos no cidadão comum, representado por funcionários daquela empresa, um modelo mental do ambiente bastante tênue, pouco elaborado ou indistinto.

Oras, estes indivíduos são tão produtores do espaço quanto aqueles que exercem funções político-administrativas ou empresariais. Como conjunto, todos interagem com o meio, se adaptam e adaptam o meio às suas necessidades e objetivos promovendo alteração ambiental.

$\mathrm{Na}$ alteração ambiental a consideração do tempo é fundamental, pois todos os seres alteram o meio porém não com a mesma intensidade, capacitação técnica, constância ou rapidez como o homem. Alterações constantes ou agudas podem ser drásticas e podem significar exclusão de outros seres e do próprio homem dos ambientes afetados.

Odum (1988: 180) considera que, apesar de ser um processo arbitrário, pode ser instrutivo considerarmos o estresse antropogênico sobre os ecossistemas nestas duas categorias: 1) o estresse agudo, caracterizado pelo início repentino da perturbação, por um aumento abrupto da intensidade e pela curta duração; e 2) o estresse crônico, que envolve uma longa duração ou uma recorrência freqüente, mas não uma alta intensidade.

Ainda afirma que os ecossistemas naturais exibem maior capacidade de se recuperarem do estresse agudo do que do estresse crônico, [desde que a alteração aguda não se dê por substâncias tóxicas].

Devemos aqui distinguir, também no sentido instrutivo, ecossistemas naturais e o meio humano.

Cidades e terras agropecuárias são o meio humano, quase que exclusivamente. São ecossistemas que devem ter qualidade ambiental mas isto significa ter condições que não causem doenças físicas e mentais. 
Qualidade ambiental não significa semelhança ao ambiente natural, referido como aquele que oferece possibilidades de vida a uma ampla variedade de espécies. Mas significa proximidade a ele.

E o homem se volta para este ambiente natural, para recreação e descanso. Procura então mesclar o construído e o natural, em diversas escalas, do vaso na janela ao parque nacional. E confunde paisagem (aspecto primariamente visual do ambiente) com ambiente (suporte físico e social da existência, em constante mudança).

Apesar dos valores estéticos serem variáveis, assume importância a paisagem e, de modo geral, as alterações no ambiente não são objeto de avaliação.

Paisagem, assim, confunde-se com espaço, não o geográfico, mas aquele que vemos ao longe e de longe.

O homem não se vê cotidianamente como agente da paisagem e do ambiente. Cuida de sua casa, mas não de sua rua, de seu bairro, de sua cidade. Delega estes cuidados ao Estado, não se dando conta que a integridade do lugar construído deve ser mantida por meio de ritos, que pressupõe a participação de todos.

Usa seus lugares, de moradia, de trajeto, de trabalho, de compras, e diferencia-os como 'meu e não meu'. Mas o meio natural permanece como o espaço indiferenciado, sem funções, ao longe.

O cidadão termina por não atuar localmente nem em escala maior.

A obra de Eugene Odum (1988) sistematizando as condições ecoenergéticas de ambientes humanos, rurais nesta nossa referência, auxilia a distinção do ambiente natural.

Buscando produção máxima de energia por colheita, o homem simplifica os sistemas naturais formando monoculturas. Ambientes mais complexos, com maior biodiversidade, ficam mais próximos de ecossistemas maduros (de clímax) nos quais o fluxo energético é maior para manutenção do que para crescimento.

Ecossistemas jovens, em fases iniciais de sucessão, com pouca diversidade em espécies, apresentam fluxo energético maior para crescimento (produção) e menor para manutenção (respiração); são mais produtivos. 
Mas Odum (1988: 310) se mostrou defensor da necessidade de paisagens improdutivas, com ecossistemas maduros, para promover qualidade de vida também ao homem. Sugeriu a compartimentalização da paisagem, com unidades produtivas e não-produtivas, sujeitas a estratégias diferentes de gerenciamento.

Práticas de zoneamento econômico-ecológico partem destes conceitos ecossistêmicos abertos à consecução da interação mais favorável na localização de usinas de energia, indústrias, habitações, campos agrícolas e áreas naturais.

Dentro deste enfoque, municípios têm criado distritos ou parques industriais, mas Manzagol (1985: 12) nos lembra que "o espaço industrial não se restringe à pequena fração territorial ocupada pelas fábricas. ... (Existe) uma rede de fluxos visíveis (mercadorias) e invisíveis (capital, informação)" centrada nas unidades de produção e administração.

Assim Manzagol define dois tipos de invólucros espaciais da empresa: o espaço de ação ou intervenção, e o espaço potencial ou de oportunidade (id. ib.: 130).

Se a organização do espaço é governada pela localização das atividades econômicas, entendemos aqueles fluxos como fatores da produção de espaço.

Ou seja, a instalação de determinada indústria em um local não só reorganiza aquele ponto e seu entorno mas produz espaço em cada habitação de funcionário que contrata, nas ações públicas providas por taxas e impostos, em cada instalação comercial que adquire seus produtos, em cada fornecedor que representa a reprodução deste processo.

Esta produção de espaço não se dá somente pelo fluxo de mercadorias e capital, mas também de informações cujo sentido podemos estender para as representações de meio ambiente de que tratamos.

Quanto à produção do espaço, devemos considerar que não é processo homogêneo, mas desigual.

São desigualdades geradas pelas estruturas econômicas, que trazem diferenças locacionais, geralmente com parcelas da população ocupando áreas menos favorecidas, tanto topograficamente quanto por serviços públicos básicos. 
Em outros termos, a produção de espaço é desigual pelas desigualdades intrínsecas ao espaço urbano caracterizado como fragmentado pelos diferentes usos que se ligam pela circulação das pessoas, em suas diversas motivações e campos simbólicos, e pelo fluxo de mercadorias.

Compreendemos de uma obra de Milton Santos (1994) que estes fluxos são desiguais.

Milton Santos explica que hoje a natureza não é mais socialmente transformada, socialmente possuída e socialmente apropriada. Hoje, a natureza artificializada das cidades está a serviço de alguns.

"Isso atribui, na cidade, uma significação diferente, específica, diferencial a cada indivíduo, a cada grupo, a cada firma, a cada instituição e, ao mesmo tempo, a cada distrito, a cada bairro, a cada rua" (Santos, 1994: 140).

Nos interessamos por estas individualidades ou situações ímpares na delimitação do estudo de caso buscando uma compreensão do processo de informação e produção de espaço.

Neste processo de informação, nos preocupamos com a homogeneidade e falta de riqueza perceptiva dos cidadãos que entrevistamos.

Reconhecemos que os pensamentos (representações) expressos nas falas (signos) são parciais em relação ao objeto porque partem de concepções do objeto representado, conforme conceito de Lucrécia Ferrara (1999: 63). Mas entendemos que as concepções sobre o ambiente daqueles sujeitos de nossa pesquisa estão simplificadas, empobrecidas.

Ferrara (1999) explica que o hábito torna a cidade ilegível, irredutível ao conhecimento e à ação consciente; o pensamento acaba refratário à reflexão e a cidade se torna imperceptível. Em um ambiente familiar a objetividade da percepção visual é reduzida, e a realidade ambiental existente torna-se silenciosa em seus signos.

Assim, sem receber informação ambiental, não há juízo perceptivo, crítica que levaria a ações conseqüentes, individual ou coletivamente, para criar ou assegurar a qualidade ambiental. 
Neste ponto Ferrara (1999) coloca um paradoxo: a percepção ambiental informacional e judicativa traz como conseqüência a cidadania que se revela por meio das conseqüências práticas daquela percepção.

Cidadania entendida como participação a qual "supõe capacidade de gerar informação crítica sobre o cotidiano: uma ágil capacidade inferencial capaz de produzir, a partir da informação de massa, um juízo informacional atuante" (id. ib.: 79).

Importante voltarmos para a definição de qualidade ambiental.

Os ecossistemas apresentam qualidades biológicas e abióticas que os definem como distintos, ou seja, ocorrem ecossistemas com alta biodiversidade e úmidos ou com baixa biodiversidade e secos. Mas, além disto, existem padrões já estabelecidos de qualidade da água, do ar e do solo, lidando com a manutenção de formas de vida com saúde.

A isto que denominamos graus de poluição, acrescenta-se na mensuração da qualidade ambiental para ambientes urbanos o nível de abastecimento de água potável, coleta e tratamento de esgotos, rede elétrica de iluminação, coleta, disposição e tratamento de resíduos sólidos, abertura de vias públicas adequadas, acesso à moradias seguras, áreas verdes e de recreação, higidez dos alimentos, incidência de doenças, assistência à saúde e social, disponibilidade de emprego, equipamentos de transporte, escolas, centros comunitários e segurança.

Entendemos que psicologicamente cada pessoa tem uma percepção do meio ambiente e de sua qualidade, mas limitada pela condição humana e que se processa dentro de padrões culturais, geográficos e históricos.

Assim como varia a percepção, variam os valores atribuídos ao meio ambiente e variam as atitudes. Mas existe uma imagem pública, comum, de ambiente urbano com qualidade: aquele com alto nível, ou melhor, alta quantificação dos fatores acima mencionados.

É necessário falar em quantificação para fazer referência à infraestrutura e não à estrutura ou à forma das cidades mantendo-se assim a relevância da diversidade de formas e soluções.

Refletindo sobre o espaço citadino, encontramos que nele se destaca o conceito de lugar e de tempo, ambos marcados pela cotidianidade impregnada pela cultura e o imaginário. É como se as cidades não 
existissem, mas apenas lugares que Lemos (1999: 20) considera como componentes de nossa identidade de sujeitos, como centros de significados, como condições da própria existência, "foco de vinculação emocional para os seres humanos, contexto para as nossas ações.... O lugar concentra significados, pensamentos e os sentimentos dos seus habitantes".

Esta autora, Lemos, ainda considera que nas metrópoles o lugar é uma realidade fragmentada.

Texto de Ana Fani Carlos (1994: 42) não tanto discorda desta observação mas a completa quando afirma que o lugar não se define pela escala "mas como parte integrante de uma totalidade espacial fundamentada no desenvolvimento desigual". Em sua perspectiva o lugar é representação espacial, definida a partir da divisão (espacial) do trabalho.

O lugar é assim entendido como produto, fragmento de uma totalidade maior, e também como condição de existência e contexto para ações; é onde ocorrem as representações.

Em outro sentido, o sujeito é produtor de espaço mas também é influenciado por este espaço produzido, consideração esta que nos retoma a preocupação com os espaços 'dados' aos indivíduos pelos arranjos político-administrativos e econômicos.

Quando pensamos em uma cidade temos em mente muitos sujeitos e um espaço, tornando necessária a interação entre estes muitos sujeitos. Ou seja, a formação de um conjunto singular.

Consideramos que esta singularidade se forma pelo que Véras (2000: 99) chama de "caráter fixo e imóvel do ambiente construído que passa a acarretar os fortes efeitos de vizinhança ou de externalidade".

Assim podemos dar importância ao bairro, ao distrito, à cidade, quando pensamos em lidar com a percepção e atitudes ambientais de um conjunto de indivíduos.

Mas devemos também dar importância às relações sociais que se estabelecem entre os indivíduos. 
Tomando como base a obra de Henri Lefebvre (que apontamos na Introdução deste estudo), Gottdiener (1997: 290) aborda uma revolução do design espacial com a desalienação da vida cotidiana e solução do conflito social que nasce da pulverização do espaço pelas relações da propriedade privada, e considera que "o pensamento sócio-espacial deve ser redirecionado de uma análise da economia para a transformação das relações sociais".

Completa Gottdiener que este redirecionamento "requer um retorno à luta por uma vida comunitária equilibrada que desenvolva no espaço relações sociais transformadoras" (id. ib.: 290).

Vimos trabalhando com o conceito da imagem pública, comum, de senso comum. Retomando este conceito:

"o senso comum é um conjunto de informações não-sistematizadas que aprendemos por processos formais, informais e, às vezes, inconscientes, e que inclui um conjunto de valorações. Essas informações são, no mais das vezes, fragmentárias e podem incluir fatos históricos verdadeiros, doutrinas religiosas, lendas ou parte delas, princípios ideológicos às vezes conflitantes, informações científicas popularizadas pelos meios de comunicação de massa, bem como a experiência pessoal acumulada" (Matallo Jr., 1988: 16).

Mas são elas, estas informações, que permitem toda e qualquer observação.

As informações de que falamos são os blocos para o pensamento, acompanhadas de valorações que acabam por direcionar tanto o senso comum (o pensamento) quanto as atitudes.

Abordando apenas sua gênese, o pensamento científico também parte de informações prévias e observações mas procura se distanciar de valorações através de argumentações racionais e coerentes.

Estes pensamentos são formas de conhecimento o qual, repetindo definição de Antônio Joaquim Severino (1994: 82) "é a capacidade dos homens de encontrar / atribuir um significado para os elementos que caem em seu campo de experiência, mediante a utilização de conceitos (como mediadores)". 
Isto implica na educação, na transmissão de informações e conceitos, que estamos discutindo.

Tendo como objeto o meio ambiente, a educação ambiental tem sido tão propagada quanto criticada. Propagada em publicações, cursos, programas e políticas públicas e criticada, não tanto nos enfoques, mas no alcance de seus objetivos e por ser considerada remédio para todos os males... ou embrulho destes males...

Vista positivamente e voltando-se para as cidades concordamos com Ferrara (1999: 79) quando afirma que a educação ambiental deve "preparar indivíduos capazes de uma percepção urbana que lhes possibilite selecionar alternativas de ação, capacidade indispensável ao exercício da cidadania”.

Aqui falamos de percepção como capacidade de ler o ambiente, isto é, de compreender o que se passa nele. Estudos da história natural e social do lugar e realização de diagnósticos sócio-ambientais de uma região têm sido utilizados para o desenvolvimento desta percepção.

Estes processos de formação e educação, em termos de descrição e interpretação, são também defendidos por Dansereau (1999) e Peter Thomas (1993).

Este autor, Thomas (1993), verificou que cursos de ecologia - não formais, para adultos - deixaram de ser tão populares na Inglaterra como o eram. Conjeturando sobre as causas deste decréscimo de interesse, levanta a complexidade alcançada pelos métodos de estudo da ecologia, a inclusão de política e ambientalismo nos cursos e até a presença de assuntos depressivos como chuva ácida, aquecimento global e problemas com parques nacionais.

Mas considera que o encorajamento de conhecimento ecológico no público em geral é importante para aumentar a apreciação e a qualidade de vida individual, para estimular ações conservacionistas comunitárias, e para aumentar a pressão pública nas mudanças de políticas governamentais.

Reconhecemos que estudos de campo contribuem para a educação ambiental provendo experiências concretas sobre o ambiente, facilitando a descoberta de interrelações entre os ambientes físico, biológico e social, e, desta maneira, motivando a apreciação e o senso de responsabilidade pela conservação do ambiente. 
Porém causa certa surpresa propostas que encontramos como de Costanza (1991) sugerindo que, em adição à compreensão básica de seus princípios, a visão ecológica deve incluir uma apreciação do papel dos organismos como retenção de água, polinização, controle de pragas, etc.

Além de técnico-material, é uma visão utilitária dos diversos seres vivos como se devêssemos preservá-los pelo trabalho que efetuam para as comunidades humanas.

Sobre estudos naturais, concordamos mais com posições como de Pepi (1994) quando afirma que uma apreciação inteligente da natureza é uma forma de crítica baseada na crença de que a natureza contém valores inerentes. Devemos ter em mente tais valores ou a busca de um senso comum, ontológico, no estudo de modelos mentais do ambiente que conduzem as ações sobre o espaço.

Nesta situação de produção de espaço pelo Estado e pelo capital, com suas representações que vimos técnico-materiais no estudo de caso, e nesta necessidade de desalienação dos cidadãos para participação efetiva no espaço, se coloca a educação ambiental.

Mas é mister questionar as práticas correntes desta educação.

A educação ambiental adquiriu relevância internacional a partir da Conferência para o Meio Ambiente realizada em 1972. Em 1977 realizou-se a Conferência Intergovernamental sobre Educação Ambiental em Tbilisi, antiga URSS, postulando que

"a Educação Ambiental é um elemento essencial para uma educação global, orientada para a resolução dos problemas por meio da participação ativa dos educandos na educação formal e não-formal, em favor do bem-estar da comunidade humana" (Medina, 1997: 259).

A Conferência para o Meio Ambiente de 1992, realizada no Rio de Janeiro, manteve a importância de programas de educação permanente sobre meio ambiente e desenvolvimento centrados nos problemas locais de cada comunidade. 
Seguindo mudanças de foco, do global para o local, muito se fez em educação ambiental nestes 30 anos e não temos aqui a pretensão de uma ruptura, mas sim de contribuir com reflexões para organizar e reorganizar programas de informação, comunicação e educação sobre o meio ambiente.

Ou seja, vemos necessidade de formas de difusão de conhecimentos sobre o meio ambiente que ampliem a visão crítica dos indivíduos, que os instiguem a questionar as representações que se mostram quase consolidadas, e, especialmente, que indiquem possibilidades de atuação.

Passamos, assim, à última parte desta retomada do diálogo entre modelos de meio ambiente.

\subsection{Difusão de conhecimentos sobre o meio ambiente para atitudes valorativas e participativas}

Neste nosso estudo, para ampliar a compreensão da difusão de conhecimento ambiental na indústria optamos por verificar como se dá o diálogo entre os modelos de meio ambiente empresarial e do senso comum conduzindo a atitudes valorativas e participativas em relação ao meio ambiente.

Partimos da hipótese que tal diálogo entre os modelos empresarial e do senso comum deve se basear em conhecimento ecológico e a educação ambiental dos trabalhadores de uma empresa deve se pautar também em história natural e ser voltada para a localidade que habitam.

Acrescentamos agora o planejamento ambiental como tópico importante na educação ambiental dos indivíduos.

Vimos no estudo de caso a presença, reprodução e permanência de um modelo técnico-material do meio ambiente na instância pública, na empresa e entre os funcionários.

É um modelo que traz como preocupação o fluxo de matéria e a ecoeficiência (redução de materiais, rejeitos e energia com a mesma produtividade).

Discutimos que este modelo não representa sustentabilidade por não compreender os aspectos sócio-culturais do conceito de qualidade de vida urbana e os aspectos ecológicos dos ambientes naturais. 
No estudo de caso a descrição do espaço, ou seja, do município de Vinhedo, nos forneceu um modelo institucional, político-administrativo do meio ambiente.

Mas pudemos considerar esse modelo como o modelo acadêmico que definimos no início do trabalho. Porém, neste ponto, precisamos discerni-lo de 'conhecimento ecológico' que vimos delineado no capítulo 1 e que compreende visões mais amplas, ecossistêmicas.

Assim, discutindo nossa hipótese, consideramos que o conhecimento ecológico pode trazer uma maior diversidade e questionamento conceitual no diálogo entre diversos sujeitos.

Não se enaltece a ciência mas sua disposição para o debate e para a observação de fenômenos variados ocorrendo numa mesma localidade.

Quanto à educação ambiental dos cidadãos, para a qual a empresa pode contribuir dentro de seu programa de gestão ambiental, mantemos a proposição de ser baseada em conhecimento ecológico, em história natural, e voltada para a localidade.

O conhecimento ecológico, aqui, significa visão de relações entre as partes que constituem uma localidade. E a história natural nos traz as possibilidades de apreciação da natureza e de senso de lugar que vimos como importantes nos capítulos 1 e neste.

Vimos na homogeneidade e simplicidade da visão ambiental dos trabalhadores que entrevistamos uma ausência de leitura do espaço. $O$ objetivo é alterar esta situação, tornar o cidadão mais observador e crítico pois sem observação e juízo não pode haver ação e construção consciente do espaço.

Basear a educação ambiental em tópicos de história natural é exatamente para incrementar a capacidade de observação dos sujeitos, visto que não podemos perceber o que não conhecemos, ou melhor, o que não reconhecemos.

Uma vez que distinguimos e descrevemos aspectos do ambiente, bióticos e abióticos, podemos relacioná-los, e, sem dúvida, nisto contribui a disciplina da ecologia. 
Evitando o risco do esteticismo e do tecnicismo nos quais podem recair a história natural e a ecologia, pensamos no planejamento ambiental como instrumento da educação.

Eduardo Yázigi $(2001: 236,244)$ aponta para a "produção planejada do espaço" da qual "o princípio da participação é inseparável". Discute o trânsito entre centralização e descentralização na "inclusão da participação como sistemática do processo de planejamento" e a necessidade democrática das categorias representativas, grandes e pequenas, se expressarem num "conselho deliberativo de planejamento" que orientaria as decisões comunitárias.

Pensamos que uma educação ambiental também baseada nos atos de planejar incentiva e propicia a participação.

O planejamento ambiental articula território, aspectos bióticos e abióticos do meio, aspectos sócio-culturais e econômicos. Expõe a busca das unidades operacionais espaciais necessárias a todas as suas etapas (inventário, análise, diagnóstico, planejamento propriamente dito e gestão) (Mauro, 1997: 16).

E pode se definir em níveis como o ordenamento ambiental, os planos de gestão ambiental, a avaliação de impactos e riscos de projetos e a auditoria ambiental.

Como características que interessaram, face à reprodução de um mesmo modelo de meio ambiente, encontramos que o planejamento ambiental, em sua concepção, aborda múltiplas opções, buscando a combinação e a variedade, e reconhece a incerteza (Chávez, 1993).

Em todo seu escopo o planejamento ambiental permite identificar a realidade territorial, conflitos atuais, possíveis soluções e novas propostas.

Além disto expõe lacunas de conhecimento e o tratamento multidisciplinar dos temas, itens valiosos para um enfoque precautório das questões ambientais e para as possibilidades de participação da comunidade.

Programas de educação ambiental baseados em planejamento ambiental podem colocar os sujeitos como responsáveis diretos pela ocupação dos espaços e pela avaliação da sua adequação, instrumentandoos para o diálogo com as instâncias públicas. 
Baseado em análises integrativas e em correlações entre variáveis, o planejamento ambiental possibilita a compreensão dos múltiplos usos dos espaços e do papel dos diversos atores sociais.

Para que se realize exige conhecimento do meio físico, portanto percepção ambiental em várias escalas, conhecimento do meio biológico, suas características e fragilidades, e conhecimento antrópico, incluindo a dinâmica sócio-econômica com análise retrospectiva e projeção de cenários futuros.

Como o planejamento ambiental permite o ordenamento de espaços com definições das necessidades para adequação ou recuperação, uma educação ambiental nela baseada pode fornecer aos sujeitos a possibilidade daqueles ordenamentos e definições.

A metodologia do planejamento ambiental faculta a compreensão de interrelações e, especialmente, de ações para a produção social do espaço, que não permanece como algo dado mas como algo objetivado.

Permite também a compreensão de limites, das áreas, dos solos e recursos hídricos, dos ecossistemas e das potencialidades econômicas.

Encontramos programas de educação ambiental voltados a levantamentos, diagnósticos e propostas de soluções, mas o que queremos aqui reforçar é a visão do espaço ocupado como produto social.

Esta visão se destaca na metodologia do planejamento que implica decidir o que deve ser feito para alcançar um objetivo.

Mas devemos considerar que atividades de planejamento também dispõem de um marco conceitual que conduz o modelo ideal abstrato daquilo que se deseja incluir no sistema que será planejado.

Se o sistema é um determinado espaço ocupado pelo homem, o plano seleciona áreas e se planejam os critérios para selecionar, estabelecer e dirigir aquelas áreas que compõem o sistema.

Com estas características o planejamento ambiental é instrumento rico para a participação consciente da coletividade.

E, como atividades de planejamento são freqüentes nas instâncias públicas e empresariais, a instalação de programas de educação ambiental com este enfoque seria facilitada, ao menos metodologicamente. 
$\mathrm{Na}$ análise de Vinhedo apontamos ações ambientais da Prefeitura Municipal, como revegetação de margens de rios e preservação de matas, que são significativas em planejamento ambiental, como verificamos em estudo de Richard Forman (1997).

Forman (1997) considera componentes de máxima prioridade num plano, pelos benefícios ecológicos que produzem, a manutenção de grandes manchas de vegetação, corredores largos de vegetação ao longo dos cursos d'água, manutenção de conectividade entre as grandes manchas e manutenção de trechos naturais heterogêneos no meio das áreas construídas.

Porém não encontramos valorização destas ações pela comunidade, possivelmente por ausência de difusão e de discussão.

Operacionalmente, programas de educação ambiental para análise e crítica incluem representações espaciais (plantas, mapas, maquetes) que, como linguagem, exigem uma leitura própria mas referente ao seu objeto, o ambiente ao qual se referem.

Esta não é uma leitura automática, mas aprendida, exigindo o conhecimento de signos próprios e a realização de exercícios de representações espaciais.

Em não havendo esta instrumentação, a leitura cartográfica caracteriza detenção de poder e impede a participação. Ou seja, quando numa reunião comunitária estendemos um mapa ou uma planta quase desfraldamos uma bandeira territorial!

Nos trabalhos de educação ambiental devemos ser cautelosos com as habilidades perceptivas de cada indivíduo, variadas e subjetivas.

Com relação a habilidades perceptivas podemos retomar nossa dissertação de mestrado (Zolcsak, 1997) onde analisamos a percepção que os visitantes de parques zoológicos têm de ambientes de animais cativos. Verificamos que não estabelecem relações entre os animais e seus ambientes - não notam os ambientes.

Neste aspecto citamos Kaplan e Kaplan (1989) que, em estudo posteriormente muito aplicado por outros autores em planejamento ambiental, utilizaram um modelo de variáveis informacionais onde as preferências ambientais são estruturadas pelos processos cognitivos de 
compreensão (coerência e legibilidade) e de exploração (complexidade e mistério).

Determinaram, em paisagens, características de coerência, legibilidade, complexidade e mistério, verificaram que as paisagens preferidas pelos observadores são aquelas que apresentam maior número daquelas características.

Para permitir o desenvolvimento da visão do ambiente, propusemos, na dissertação citada, o uso da cenografia como hierarquização dos elementos.

A cenografia é a apropriação, pelo teatro, de uma técnica pictórica de expressão do espaço a partir de um ponto de vista, a perspectiva, que se identifica com o modo humano de se apropriar do visível (Aumont, 93: 229).

Se este 'modo humano' faz da visão humana a regra da representação, como opção simbólica, a hierarquização de elementos da paisagem representada é opção simbólica para os educadores ou comunicadores, considerando-se os objetivos educacionais relativos ao meio ambiente.

Consideramos que esta hierarquização pode ser aplicada nos inventários e diagnósticos do planejamento ambiental.

Ainda para discutir o planejamento ambiental como instrumento de educação ambiental, queremos citar um livro em forma de quadrinhos preparado por Maurício Ribeiro (1979) e ilustrado por Claudio Martins.

Reproduzimos alguns trechos ilustrativos:

"No principio, era um terreno descampado com suas ondulações naturais e propriedades rurais ....

Surgiram então as primeiras casas....

A topografia natural do terreno e os parcelamentos rurais condicionavam a forma da cidade que surgia....

Mas o parcelamento, a ocupação e o uso do solo não se dão da mesma forma em todas as partes da cidade - nas favelas, por exemplo, primeiro ocupam-se as terras, dá-se um uso às construções, e o parcelamento do terreno é o resultado deste processo, que não tem um plano pré-estabelecido para acontecer. ...

Quantas maneiras haveria de se organizar o território e os assentamentos humanos, de modo a se conservar energia e reduzir as desigualdades?

Um instrumento básico seria um mapa dos fluxos reais de energia entre áreas rurais e urbanas. ..." (Ribeiro, 1979). 
Consideramos a abordagem interessante mesmo discordando da linguagem densa e do peso que o autor coloca, em outros trechos, no trabalho de especialistas, deixando a participação da população no nível do consumo-não consumo.

Claro que a avaliação de níveis de consumo é importante, mas levar o cidadão a entender a produção espacial, a ordenação, o planejamento do ambiente, para incrementar sua percepção judicativa, é a intenção deste estudo.

E estas estratégias educacionais podem se desenvolver na prática considerando-se os grupos de cidadãos já constituídos nas empresas, especialmente em municípios de menor porte como Vinhedo.

No âmbito educacional não se trata de fazer estudos do meio, mas de haver uma troca entre grupos comunitários e especialistas os quais devem expor suas abordagens e podem, assim, conhecer as condições de vida e de atuação dos grupos constituídos.

É quase uma pesquisa-ação, de que trata Thiollent (2000: 93), que reconhece nesta ação pedagógica a necessidade de distanciamento entre 0 conhecimento cientifico e as representações imediatas sugeridas pelo senso comum para evitar o empiricismo e o subjetivismo. 


\section{CONSIDERAÇÕES FINAIS}

Quando pensamos em planejamento não nos referimos a planejamento participativo mas no entendimento de planejamento ambiental (incluindo o ambiente urbano) pelos sujeitos de um programa de educação ambiental visando sua melhor instrumentalização para atuação e participação em planos.

Trata-se de educar para o planejamento, com suas premissas.

Documentos internacionais voltados para desenvolvimento sustentável, como a Agenda 21, recomendam políticas ambientais, planejamento e gestão ambiental participativa, significando produção do espaço com incorporação da dimensão ambiental e engajamento da população.

Compreendendo gestão ambiental como uso de instrumentos normativos, de fiscalização e controle, preventivos e corretivos, a ela se antepõe o planejamento ambiental.

Consideramos clara a necessidade de eficácia no direito à informação, que inclui educação, mas não basta a repetição de modelos para uma participação efetiva.

Os cidadãos devem apresentar representações sociais bem desenvolvidas para compreender a degradação ambiental. Ou caem no risco de repetir causações e apoiar planos de sustentabilidade que implementam medições, análises e proteção de áreas restritas.

Não basta uma educação baseada em projetos de pesquisa e em intervenções participativas a partir do levantamento de problemas ambientais. As tendências da coletividade podem ser tão passivas quanto a mera consideração de suas necessidades.

É preciso entender planos e a produção de espaço que está nas mãos do Estado e das forças econômicas para minimizar contradições entre o público e o privado perpetuadas pelo mercado.

Planejamento é assim um instrumento político, além de técnico, que deve estar ao alcance dos cidadãos. 


\section{REFERÊNCIAS BIBLIOGRÁFICAS}

Acot, Pascal. História da ecologia. Rio de Janeiro, Campus, 1990.

Acselrad, Henri. Sentidos da sustentabilidade urbana. In: Acselrad, Henri, org. A duração das cidades. Rio de Janeiro, DP\&A Editora, 2001. p. 27-55.

Atkisson, Alan. Desenvolvimento de indicadores de comunidades sustentáveis - lições do Seattle sustentável. Curitiba, MMA, Universidade Livre do Meio Ambiente, 2000.

Aumont, Jacques. A imagem. Campinas, Papirus, 1993.

Bachelard, Gaston. O novo espírito científico. Lisboa, Edições 70, 1986.

Baer, Werner e Mueller, Charles C. Aspectos ambientais do desenvolvimento do Brasil. In: Baer, Werner. A economia brasileira. São Paulo, Nobel, 1996. p. 330-361.

Barbieri, José Carlos. Desenvolvimento e meio ambiente. As estratégias de mudanças da Agenda 21. Petrópolis, Vozes, 1997.

Becker, Howard S. Métodos de pesquisa em ciências sociais. 4ª ed. São Paulo, Hucitec, 1999.

Berger, Peter L. e Luckmann, Thomas. A construção social da realidade. Tratado de sociologia do conhecimento. $8^{\mathrm{a}}$ ed. Petrópolis, Vozes, 1990.

Brewer, William. Scientific theories and naive theories as forms of mental representations: psychologism revived. Science \& Education 8: 489-505, 1999.

Brinck, Ingar e Gardenfors, Peter. Representation and self-awareness in intentional agents. Synthese 118(1): 89-104, 1999. 
Bronowski, Jacob. Origens do conhecimento e da imaginação. Brasília, UnB, 1985.

Bunchaft, Guenia et al. Estatística sem mistérios. Petrópolis, Vozes, 2000.

Caporali, Renato. Do desenvolvimento econômico ao desenvolvimento sustentável. Curitiba, MMA, Universidade Livre do Meio Ambiente, 2000.

Carlos, Ana Fani Alessandri. A (re)produção do espaço urbano. São Paulo, EDUSP, 1994.

Carlos, Ana Fani Alessandri. O consumo do espaço. In: Carlos, Ana Fani Alessandri, org. Novos caminhos da geografia. São Paulo, Contexto, 1999. p. 173-186.

CBH-PCJ - Comitê das Bacias Hidrográficas dos Rios Piracicaba, Capivari e Jundiaí. Situação dos recursos hídricos das bacias hidrográficas dos rios Piracicaba, Capivari e Jundiaí. Relatório Técnico Final. Piracicaba, 2000a.

CBH-PCJ - Comitê das Bacias Hidrográficas dos Rios Piracicaba, Capivari e Jundiaí. Plano da Bacia Hidrográfica 2000-2003. Relatório Final. Piracicaba, 2000b.

CETESB. Relatório. Bacia hidrográfica do rio Piracicaba. São Paulo, CETESB, 1986.

Chauí, Marilena. O que é ideologia. São Paulo, Brasiliense, 1994.

Chávez, J. La planificácion ambiental. Mexico, IPIV, 1993.

Cobern, William, W. Worldview theory and conceptual change in science education. Science Education 80 (5): 579-610, 1996. 
Coeterier, J.F. Dominant attributes in the perception and evaluation of the Dutch landscape. Landscape and Urban Planning 34: 27-44, 1996.

Coltrinari, Lylian. A geografia física e as mudanças ambientais. In: Carlos, Ana Fani Alessandri, org. Novos caminhos da geografia. São Paulo, Contexto, 1999. p. 27-40.

Comune, Antonio Evaldo. Meio ambiente, economia e economistas: uma breve discussão. In: May, Peter Herman e Motta, Ronaldo Serôa da, orgs. Valorando a natureza. Rio de Janeiro, Editora Campus, 1994. p. 45-59.

Conti, José Bueno. A geografia física e as relações sociedade-natureza no mundo tropical. In: Carlos, Ana Fani Alessandri, org. Novos caminhos da geografia. São Paulo, Contexto, 1999. p. 9-26.

Costa, Newton Carneiro Affonso da. O conhecimento científico. São Paulo, Discurso Editorial, 1997.

Costanza, Robert, ed. Ecological economics: the science and management of sustainability. New York, Columbia University Press, 1991.

Cottrell, Stuart P. e Graefe, Alan R. Testing a conceptual framework of responsible environmental behavior. The Journal of Environmental Education 29(1): 17-27, 1997.

Creso, Franco et al. From scientists' and inventors' minds to some scientific and technological products: relationships between theories, models, mental models and conceptions. International Journal of Science Education 21(3): 277 - 291,1999.

Dansereau, Pierre. A terra dos homens e a paisagem interior. Belém, UFBA/NAEA, 1999. 
Delizoicov Neto, Demétrio. Conhecimento, tensões e transições. São Paulo, Faculdade de Educação/USP, Tese (Doutorado), 1991.

Dollfus, Olivier. O espaço geográfico. Rio de Janeiro, Bertrand Brasil, 1991.

Ferrara, Lucrécia D'Alessio. Olhar periférico. São Paulo, EDUSP/FAPESP, 1993.

Ferrara, Lucrécia D'Alessio. As cidades ilegíveis. Percepção ambiental e cidadania. In: Del Rio, Vicente e Oliveira, Lívia de, orgs. Percepção ambiental. A experiência brasileira. $2^{2}$ ed. São Carlos, Ed. UFSCar, Nobel, 1999.

Feyerabend, Paul K. Contra o método. Rio de Janeiro, Francisco Alves, 1985.

Forman, Richard T.T. Land mosaics: the ecology of landscapes and regions. Cambridge, Cambridge University Press, 1997.

Fourez, Gérard. A construção das ciências: introdução à filosofia e à ética das ciências. São Paulo, Ed. UNESP, 1995.

Fowler, Harold G. e Aguiar, Ana Maria Dias de. A integração da teoria ecológica na análise ambiental. In: Tornisielo, S.M.Tauk et al., orgs. Análise ambiental:uma visão multidisciplinar. 2ª ed. São Paulo, Ed. UNESP, 1995. p. $166-175$.

Franco, Maria de Assunção Ribeiro. Desenho ambiental. São Paulo, Annablume, 1997.

Fredericks, Isis e McCallum, David. International Standards for Environmental Management Systems: ISO 14000. Canadian Environmental Protection, 1995. 
Furtado, João S.; Silva, Eduardo Ramos Ferreira da; Margarido, Antônio C.. Estratégias de gestão ambiental e os negócios da empresa. São Paulo, Fundação Vanzolini, 2000. (www.vanzolini.org.br)

Gelman, Susan A. Concept development in preschool children. In: American Association for the Advancement of Science. Dialogue on early childhood science, mathematics, and technology education. Washington, D.C., American Association for the Advancement of Science, 1998. p. 50-61.

Gilbertson, D.D.; Kent, M.; Pyatt, F.B.. Practical ecology for geography and biology. 3rd ed. London, Unwin Hyman, 1990.

Gottdiener, Mark. A produção social do espaço urbano. São Paulo, EDUSP, 1997.

Granger, Gilles-Gaston. A ciência e as ciências. São Paulo, Ed. UNESP, 1994.

Gunther, Wanda Maria Risso et al. A educação ambiental na empresa: contribuição de uma abordagem institucional para a gestão ambiental e o desenvolvimento sustentável. In: Universidade de São Paulo. Seminário Ciência e Desenvolvimento Sustentável. São Paulo, USP, 1997. p. 310-319.

Haber, Wolfgang. System ecological concepts for environmental planning. In: Klijn, Frans. Ecosystem classification for environmental management. Dordrecht, Kluwer Academic Publ.,1994. p. 49-67.

Habermas, Jurgen. Conhecimento e interesse. Rio de Janeiro, Zahar Editores, 1982.

Hojda, Ricardo Gross. ISO 14001 - Sistemas de gestão ambiental. São Paulo, Fundação Carlos Alberto Vanzolini, EPUSP, 1998. 
Jacobi, Pedro. Moradores e meio ambiente na cidade de São Paulo. Revista de Administração Municipal, Rio de Janeiro 42 (216): 26-50, 1995.

Japiassu, Hilton F. Nem tudo é relativo. A questão da verdade. São Paulo, Ed. Letras \& Letras, 2001.

Kaplan, R. e Kaplan, S. The experience of nature. Cambridge, Cambridge University Press, 1989.

Koff, Elionora D. A questão ambiental e o estudo de ciências. Goiânia, Edit. da Universidade Federal de Goiás, 1995.

Kuhn, Thomas S. The structure of scientific revolutions. Chicago, Chicago University Press, 1962.

Lajeunesse, Denyse et al. Development and application of an ecosystem management approach for protected natural areas. Environmental Management 19 (4): 481-495, 1995.

Lanna, A. E. L. Gerenciamento de bacia hidrográfica: aspectos conceituais e metodológicos. Brasília, Instituto Brasileiro do Meio Ambiente e dos Recursos Naturais Renováveis, 1995.

Layrargues, Philippe Pomier. A cortina de fumaça. O discurso empresarial verde. São Paulo, Annablume, 1998.

Lefebvre, Henri. The production of space. Oxford, Blackwell, 1995.

Leff, Enrique. Epistemologia ambiental. São Paulo, Cortez, 2001.

Lemos, Amália Inés Geraiges de. A metropolização nos países do terceiro mundo. Revista do Depto. de Geografia/FFLCH/USP 13: 7-36, 1999. 
Lopes, Ignez Vidigal et al. Apresentação. In: Lopes, Ignez Vidigal et al., orgs. Gestão ambiental no Brasil: experiência e sucesso. Rio de Janeiro, Ed. Fundação Getúlio Vargas, 1996.

Lynch, Kevin. A imagem da cidade. São Paulo, Martins Fontes, 1960.

Ma, Xin e Bateson, David J. A multivariate analysis of the relationship between attitude toward science and attitude toward the environment. The Journal of Environmental Education 31(1): 27-32, 1999.

Maimon, Dália. Eco-estratégia nas empresas brasileiras: realidade ou discurso? Revista de Administração de Empresas 34(4): 119-130, 1994.

Manzagol, Claude. Lógica do espaço industrial. São Paulo, Difel, 1985.

Matallo Jr., Heitor. A problemática do conhecimento. In: Carvalho, Maria Cecília Maringoni de, org. Construindo o saber. Campinas, Papirus, 1988. p. 13-28.

Mauro, Cláudio Antônio de, coord. Laudos e perícias em depredações ambientais. Rio Claro, UNESP, 1997.

Medina, Naná M. Breve histórico da educação ambiental. In: Padua, Suzana M. e Tabanez, Marlene F., orgs. Educação Ambiental: caminhos trilhados no Brasil. Brasília, Ipê, 1997. p. 257-269.

Ministério do Meio Ambiente (MMA). Agenda 21. Relatório - O que o brasileiro pensa sobre o meio ambiente, desenvolvimento $e$ sustentabilidade. Brasília, MMA, 1998. 
Moore, Gary, T. e Golledge, Reginald G. Environmental knowing: concepts and theories. In: Moore, Gary, T. e Golledge, Reginald G. Environmental knowing: theories, research, and methods. Stroudsburg, Penn., Dowden, Hutchinson \& Ross, 1976. p. 3-24.

Moraes, Antonio Carlos Robert. Geografia. Pequena história crítica. $2^{\underline{a}}$ ed. São Paulo, Hucitec, 1983.

Moraes, Antonio Carlos Robert. Meio Ambiente e ciências humanas. $2^{\mathrm{a}}$ ed. São Paulo, Hucitec, 1997.

National Research Council. Ecological knowledge and environmental problem-solving: concepts and case studies. Committee on the Applications of Ecological Theory to Environmental Problems. Washington, D.C., National Academic Press, 1986.

Neder, Ricardo Toledo. Há política ambiental para a indústria brasileira? Revista de Administração de Empresas 32(2): 6-13, 1992.

Nunes, Dorisvalder Dias. Gestão ambiental em Rondônia (políticas públicas em unidade de conservação: o caso Cuniã). São Paulo, FFLCH/USP, Depto. de Geografia, Dissertação (Mestrado), 1996.

Odum, Eugene P. Ecologia. Rio de Janeiro, Guanabara Koogan, 1988.

Pereira, Júlio Cesar Rodrigues. Análise de dados qualitativos. Estratégias metodológicas para as ciências da saúde, humanas e sociais. $3^{\mathrm{a}}$ ed. São Paulo, EDUSP, FAPESP, 2001.

Pepi, David. The mechanics of nature appreciation. Journal of Environmental Education 25 (3): 5-13, 1994. 
Peters, Robert Henry. A critique for ecology. Cambridge, Cambridge University Press, 1990.

Piaget, Jean e Garcia, R. Psicogenesis y historia de la ciencia. Mexico, Siglo XXI Ed., 1984.

Pimm, Stuart L. e Gilpin, Michael, E. Theoretical issues in conservation biology. In: Roughgarden, Jonathan; May, Robert M.; Levin, Simon A., eds. Perspectives in ecological theory. Princeton, Princeton University Press, 1989. p. 287-305.

Poiani, Karen A. et al. A scale-independent, site conservation planning framework in the Nature Conservancy. Landscape and Urban Planning 43: 143-156, 1998.

Popper, Karl R. Em busca de um mundo melhor. $3^{\underline{a}}$ ed. Lisboa, Fragmentos, 1992.

Reigota, Marcos. Meio ambiente e representação social. São Paulo, Cortez Editora, 1995.

Reis, Maurício J.L. ISO 14000. Gerenciamento ambiental. Rio de Janeiro, Qualitymark, 1995.

Ribeiro, Maurício Andrés. Uma cidade se forma. Belo Horizonte, Projeto, 1979.

Roncayolo, Marcel. Les territories du temps. Paris, Editions Locales de France, 1996.

Sanger, Matt. Sense of place and education. The Journal of Environmental Education 29(1): 4-8, 1997. 
Santos, Milton. Por uma economia política da cidade. São Paulo, EDUC, Hucitec, 1994.

Santos, Milton. A natureza do espaço. São Paulo, Hucitec, 1996.

Schnitman, Dora F. e Fuks, Saúl I. Reflexões de fechamento: diálogos, certezas e interrogações. In: Schnitman, Dora F., org. Novos paradigmas, cultura e subjetividade. Porto Alegre, Artes Médicas, 1996. p. 290-294.

SEPLAN - Secretaria de Planejamento e Meio Ambiente da Prefeitura Municipal de Vinhedo. Balanço ambiental. Vinhedo, SEPLAN, 2000.

Severino, Antônio Joaquim. Filosofia da educação. São Paulo, FTD, 1994.

Stinner, A. Contextual settings, science stories, and large context problems: toward a more humanistic science education. Science Education 79: 555$581,1995$.

Swyngedouw, Erik. Power, nature and the city. The conquest of water and the political ecology of urbanization in Guayaquil, Ecuador, 1880-1990. Environment and Planning 29: 311-332, 1997.

Szaro, Robert C. et al. The ecosystem approach: science and information management issues, gaps and needs. Landscape and Urban Planning 40: 89-101, 1998.

Thiollent, Michel. Metodologia da pesquisa-ação. São Paulo, Cortez Editora, 2000.

Thomas, Peter A. The place of ecology in adult education. In: Hale, Monica. Ecology in education. Cambridge, Cambridge University Press, 1993. p. 3544. 
Ulhoi, John Parm. Training in environmental management: industry and sustainability. Luxemburg, 1996.

Valle, Cyro Eyer do. ISO 14000. Qualidade ambiental. São Paulo, Pioneira, 1995.

Véras, Maura Pardini Bicudo. Trocando olhares. Uma introdução à construção sociológica da cidade. São Paulo, Studio Nobel, Educ, 2000.

Yázigi, Eduardo. A alma do lugar. Turismo, planejamento e cotidiano. São Paulo, Contexto, 2001.

Ziman, John. Introducción al estudio de las ciencias. Barcelona, Ariel, 1986.

Zolcsak, Elisabeth. Estudo da capacidade de comunicação ambiental de exposição de animais vivos. São Paulo, Programa de Pós-Graduação em Ciência Ambiental/USP, Dissertação (Mestrado), 1997. 